IZA DP No. 10296

A Snapshot on the Quality of Seven Home Visit Parenting Programs in Latin America and the Caribbean

Jane Leer

Florencia Lopez Boo

Ana Perez Expósito

Christine Powell

October 2016 


\title{
A Snapshot on the Quality of Seven Home Visit Parenting Programs in Latin America and the Caribbean
}

\author{
Jane Leer \\ Inter-American Development Bank
}

Florencia Lopez Boo

Inter-American Development Bank

and IZA

Ana Perez Expósito

Inter-American Development Bank

Christine Powell

University of the West Indies, Kingston

\section{Discussion Paper No. 10296 \\ October 2016}

\author{
IZA \\ P.O. Box 7240 \\ 53072 Bonn \\ Germany \\ Phone: +49-228-3894-0 \\ Fax: +49-228-3894-180 \\ E-mail: iza@iza.org
}

Any opinions expressed here are those of the author(s) and not those of IZA. Research published in this series may include views on policy, but the institute itself takes no institutional policy positions. The IZA research network is committed to the IZA Guiding Principles of Research Integrity.

The Institute for the Study of Labor (IZA) in Bonn is a local and virtual international research center and a place of communication between science, politics and business. IZA is an independent nonprofit organization supported by Deutsche Post Foundation. The center is associated with the University of Bonn and offers a stimulating research environment through its international network, workshops and conferences, data service, project support, research visits and doctoral program. IZA engages in (i) original and internationally competitive research in all fields of labor economics, (ii) development of policy concepts, and (iii) dissemination of research results and concepts to the interested public.

IZA Discussion Papers often represent preliminary work and are circulated to encourage discussion. Citation of such a paper should account for its provisional character. A revised version may be available directly from the author. 


\title{
ABSTRACT
}

\section{A Snapshot on the Quality of Seven Home Visit Parenting Programs in Latin America and the Caribbean}

\begin{abstract}
Although there is ample support for the causal link between home visit parenting programs and child development outcomes, few studies have explored what it is that drives this relationship - to what extent home visit programs are implemented as designed in terms of the content and strategies used by home visitors. To our knowledge, comparable data on the quality and fidelity of implementation in home visit programs in Latin America and the Caribbean (LAC) does not exist. In light of this gap, this note presents a snapshot of home visit quality in seven countries in which home visits reach a considerable number of children. Using an observational checklist tool, we find strong rapport between visitors and families, and consistent involvement of caregivers and children in practicing activities during the visit. However, visitors rarely explain the importance of these activities in relation to child development, often times do not bring the necessary materials, and do little to encourage meaningful dialogue and feedback from caregivers nor demonstrate the desired activity or behavior. Only one third of the observed visitors emphasized language development throughout the visit. It is important to emphasize that these results are not generalizable due to the small and non-random nature of the sample of home visits observed. Nonetheless, this study serves as a pilot of the instrument and type of domains that can and should be measured in a home visit program in order to ensure implementation quality.
\end{abstract}

JEL Classification: J13, H53, H75, I38

Keywords: early childhood development, quality, home visiting programs, process quality, Brazil, Nicaragua, Peru, Panama, Jamaica, Ecuador, Bolivia

Corresponding author:

Florencia Lopez Boo

Inter-American Development Bank

1300 New York Ave. NW

Washington, DC 20577

USA

E-mail: florencial@iadb.org 


\section{Introduction}

Research from diverse fields such as psychology, biology, health, neuroscience, education, and economics demonstrates that children's experiences during the first few years of life have a longlasting impact on their future wellbeing. Poverty, and low levels of parental education, among other social and environmental risk factors, limit the ability of many parents and caregivers to provide the care and stimulation that children need (Grantham-McGregor et al., 2007). As such, targeted investments in early childhood development are increasingly recognized as a necessary strategy to ensure that all children develop to their full potential (Berlinski and Schady, 2015).

Home-visit parenting programs are one such strategy. In these programs, trained home visitors come to families' homes to deliver curricula designed to promote socio-emotional, motor, language, and cognitive development. Some home visit programs also include health, maltreatment and neglect issues in the curriculum. Evidence from experimental and quasiexperimental evaluations of home visit programs across multiple contexts demonstrates the potential of these programs to improve a wide array of health, developmental, behavioral, health and education outcomes, particularly among the most vulnerable families (See a revision of this literature in Chapter 3 in Berlinski and Schady, 2015).

In the US, the best known and arguably one of the most successful home visit programs is the Nurse-Family Partnership (NFP) program, which began in the 1970s and now operates in 32 states. The NFP is a free program that provides low-income, first-time mothers with regular home visits from a trained nurse home-visitor from pregnancy until the child is at least two years old (Olds, 2006). Several randomized controlled trial evaluations of the NFP have found an impact on multiple maternal health outcomes, such as increased attendance at birth classes, better use of nutritional supplement programs, and fewer closely spaced pregnancies (Kitzman et al., 1997; Olds et al., 1986; Olds, Henderson, and Kitzman, 1994). In terms of child outcomes, the NFP is linked to fewer emergency room visits during the first two years of life, higher intellectual functioning and receptive vocabulary by age six, and by age nine, fewer behavioral and attention problems (Kitzman et al., 2010)

In the developing world, one of the most influential and well-studied home visit programs is one that took place in Jamaica in the late 1980s. The Jamaica program targeted 129 malnourished children aged 9 to 24 months in the poorest neighborhoods of Kingston. Half of these children were randomly assigned to a control group, and the other half received a weekly home visit from a trained community health worker who demonstrated positive play and early stimulation activities to caregivers. After 24 months of programming, researchers found a large and significant effect on cognitive development (in the magnitude of 0.8 standard deviations) (Grantham-McGregor et al. 1991). By the time they were 11 years old, the cognitive scores of children in the treatment group exceeded those of the control group by 0.4 standard deviations. Most impressively, 20 years after programming concluded, youth who had participated in the home visit program had a higher IQ and educational attainment, improved mental health, less violent behavior, and about 
25 percent higher earnings than the control group (Walker et al., 2011; Gertler et al., 2014). Recent research from Colombia and Ecuador further demonstrates the potential of home visit programs (Attanasio et al.,2014; and Rosero and Ooseterbeek, 2011).

Although there is ample support for the causal link between home visits and child development outcomes, few studies have explored what it is that drives this impact. Little is known about what exactly takes place during the visit, and to what extent programs are implemented as intended. Visit content and implementation strategies vary widely depending on program guidelines, home visitor qualifications and training, and beneficiary characteristics, among other factors, but this kind of implementation data is nonetheless essential. From a programmatic standpoint, systematically collected data on the quality of implementation can be used to develop home-visitor training and supervision practices and to inform ongoing program improvement efforts. At a policy level, this kind of information is necessary in order to determine what it takes to replicate the positive effects of pilot versions of home visit programs. To bring home visit programs to scale, policy makers must determine how to keep costs at reasonable levels without sacrificing program quality. This requires unpacking the "black box" of program implementation so as to identify the processes and interactions that occur during home visits.

Existing research on the quality of implementation of home visits comes almost exclusively from the US. Analyses of one component of home visit quality-the frequency and duration of home visits--suggest that most participants only receive about half of the number of visits expected (Kitzman, 2004; Ingoldsby et al., 2013; Riley et al., 2008), and many leave the program before their eligibility ends (Duggan et al., 2000; Kitzman, 2004; Love et al., 2002)

Even in the US, however, there is limited documentation of what happens during the home visitthat is, the topics discussed, the specific strategies home visitors use, and the nature of interactions between home-visitors and families. One notable exception comes from a 2010 study of families participating in two different home visit programs, Part C and Early Head Start (Peterson et al., 2007). In this study, trained enumerators used the Home Visit Observation Form (HVOF) and the Home Visit Observation Form Revised (HVOF-R) to document the home visit process, focusing on the nature and content of interactions between home visitors, caregivers and children among 28 families participating in Part $\mathrm{C}$ and 92 families participating in EHS. Visits were videotaped and viewed simultaneously by two to three observers in order to calculate interrater reliability. ${ }^{1}$

Peterson et al. find that Part $\mathrm{C}$ home-visitors spend more than 50 percent of the visit teaching the child directly; less than one percent of the home visit time is spent modeling parent-child activities. In contrast, EHS home-visitors spend most of the visit interacting with the caregiver about familyrelated issues and various child development topics, and dedicated about 19 percent of visit time to coaching caregiver-child interactions. These results are not consistent with the stated objective of both programs, which is to strengthen families' ability to support their children's development. Nor are they consistent with the programs' implementation designs, both of which emphasize

\footnotetext{
${ }^{1}$ For Part C visits, inter-rater reliability was 0.85 , and for EHS visits inter-rater reliability was 0.88 .
} 
facilitation of parent-child interactions. Moreover, data from the HVOF-R, which includes a measure of mothers' engagement during the visit, suggests that caregivers are much more likely to be highly engaged when home visitors use coaching strategies to deliver the content, as opposed to simply having a conversation with the caregiver or interacting with the child directly.

Another study of EHS finds similar results. Vogel et al. (2015) used the Home Visit Rating Scale - Adapted (HOVRS-A) to assess the quality of EHS home visits among 240 families. Most home visits scored between 3 and 4 out of a possible score of 5 , considered "moderate quality." This score range indicates that visitors facilitate caregiver-child interactions and coach caregiver-child interactions only some of the time. Much of the visit is spent teaching the child directly or providing caregiver mentoring, rather than facilitating caregiver-child interactions (Vogel et al., 2015).

To our knowledge, comparable data on the quality and fidelity of home visit programs in Latin America and the Caribbean (LAC) does not exist. In light of this gap, this note presents a snapshot of the quality of home visits in seven countries in which home visit programs reach a considerable number of children: Bolivia, Brazil, Ecuador, Jamaica, Nicaragua, Panama, and Peru. We use an observational checklist instrument developed by the University of the West Indies and administered by a trained researcher.

Across all seven programs, we find that home visitors are generally successful at establishing a warm, positive relationship with families and children, but much less successful at following the curriculum, activities and behaviors established by the program. The activities and topics covered are age appropriate, and home visitors consistently emphasize their role as a facilitator, incorporating the mother/caregiver in games and exercises with the child. However, home visitors could do more to seek the mother's/caregiver's active participation not just in activities but also in conversation, feedback, evaluation and review of visit objectives and child development throughout the visit.

Given the small and non-random nature of the sample, our results are not representative of the seven programs visited. Rather, the main contributions of this study are (1) provide a snapshot of comparable data on home visit quality across seven programs in LAC, and (2) to demonstrate the potential of the Home Visit checklist to train, monitor and coach home visitors and their supervisors. 


\section{Methodology}

\subsection{Objectives}

The study's primary objective was to collect up-to-date data describing the nature of home visitors' interactions with caregivers and children, the content of home visit activities, and the coaching strategies utilized by home visitors, in order to identify strengths and weaknesses among programs of diverse size, scope and methodology. To date, comparable data on the quality of home-visit parenting programs in the LAC region does not exist.

\subsection{Definitions}

\subsubsection{Parenting Programs}

Developmental science has typically considered parenting programs as those directed towards fostering stimulation and affecting parent-child interactions (Engel et al., 2007; Walker et al., 2011). ${ }^{2}$ Programs focusing on nutrition, health, and neglect are usually considered outside the realm of the "parenting" umbrella.

In providing an overview of the quality of public parenting programs in the region, we take a more comprehensive view, focusing on interventions designed to foster caregiving practices $t$ that have been shown to improve child development outcomes.. In the absence of a standard term we will call these interventions parenting programs here. Across LAC, parenting programs face similar challenges, use similar delivery methods (such as home visiting), and target the marginalized or or otherwise vulnerable populations in the region or country. Analyzing these interventions together helps us to explore the potential benefits and challenges entailed in addressing multiple dimensions of caregiving behaviors and child development through home visits.

\subsubsection{Quality of home visits}

There is no universal consensus of what constitutes quality in home visit programs. Conceptions of quality are culturally and contextually dependent-what works in rural Bolivia will not necessarily work in urban Nicaragua. Moreover, existing home visit programs vary widely in terms of the qualifications and training of the home visitors, the curricula and content, the frequency and duration of the visits, and the institutional structures within which programs operate (not to mention costs). This complicates effort to develop a standard measure of quality that can be used across programs and countries.

Thus, rather than defining a specific set of standards or benchmarks that high quality programs must adhere to, the literature describes three dimensions that together constitute quality: dosage, content, and relationships (Paulsell et al., 2010). Of course, these elements do not operate in isolation - the interplay between dosage, content and relationships is also important for program

\footnotetext{
${ }^{2}$ Parenting is defined as "the process of promoting and supporting the physical, emotional, social, and intellectual development of a child" (Davies, 2000, Blackwell Encyclopedia of Social Work). Parents can promote and support the development of their children through activities associated with their hygiene, nutrition, stimulation, love, health care, and protection.
} 
quality. For example, there is evidence from the US that families are more likely to continue participating in home visit programs if they have developed a quality relationship with their home visitor-thus, relationship quality affects dosage (Olds, 2006).

Furthermore, the nature of the relationship between program quality and outcomes is not necessarily linear. Stoltfuz and Lynch (2005) find that greater dosage (more home visits) does not necessarily lead to better outcomes, for example. Likewise, there is evidence that the most successful home visitors are those who can adapt visit content to the specific needs of the family, rather than rigidly following program protocol (O'Brien et al., 2012). This requires a degree of experience, training, and confidence that may be difficult to achieve at scale, however. Regarding the link between the quality of relationships and outcomes, although there is ample evidence that higher quality relationships result in increased impact on child development, little is known about how these relationships are formed or how they work in practice. In sum, the need for more and better data on program quality is clear.

Dosage and content are structural elements of quality, meaning they can be relatively objectively and easily measured through check-list type tools designed to record the frequency, number and duration of visits, the topics covered and the activities implemented. ${ }^{3}$ Measuring relationship quality is more challenging, although the caregiver-home visitor relationship is perhaps the most important aspect of home visit quality. Indeed, the success of home visit programs depends on the capacity of home visitors to effectively communicate and empower caregivers to adopt new parenting practices. Evidence suggests that home visit programs are most effective when the information provided is done so in an interactive, engaging manner that empowers participants (Sanders et al., 2008), and when interactions between caregivers and home visitors are stable, respectful, and warm (Paulsell et al., 2010; Miller \& Rolnick, 2002; Riley et al., 2008).

All three elements can be measured by self-report, but relationship measures may be especially subject to self-report bias. Observation-based measures implemented by trained enumerators are therefore the preferred method. Given the importance of the relationship element of home visit quality, most existing instruments focus on the caregiver-home visitor relationship, while also including some aspects of dosage and content (see Schodt et al., 2015 for a description of existing tools).

\footnotetext{
${ }^{3}$ Another aspect of dosage is the amount of time that caregivers spend practicing the activities demonstrated to them by the home visitor, such as reading or playing with children. This is harder to measure in a one-off observational checklist however, and is subject to self-report bias when included in caregiver surveys.
} 


\subsection{Sample}

Our sample consists of seven parenting programs selected because they are among the only large-scale public parenting programs in LAC. ${ }^{4}$ These include three national programs: Cuna Más in Peru, Creciendo con Nuestros Hijos $(\mathrm{CNH})$ in Ecuador and Programa de Acompañamiento a la Política de Primera Infancia (PAIPPI) in Nicaragua, and three regional programs: Programa Primeira Infancia Melhor (PIM) in Rio Grande do Sul (Brazil), the Home Visits Program in Kingston and Saint Andrews (Jamaica) ${ }^{5}$, and Atención Integral de la Niñez con Participación Comunitaria (AIN-C) in Panama. We also include an additional program implemented at the municipal level by the NGO Consejo de Salud Rural Andino (CSRA) in El Alto, Bolivia.

Five of the seven programs focus primarily on language, social and motor development (the Jamaican Home Visit Program, PIM, Cuna Más, PAIPPI and CNH), and are referred to as comprehensive development programs from here on). Some of these programs also go beyond, focusing on preventing maltreatment (PAIPPI) or handwashing behaviors (Cuna Mas). The programs in Bolivia and Panama are nutrition programs, focusing on healthy feeding practices for expecting mothers and young children. Further information on the structure and methodology of each program can be found in Appendix 2.

Between May and August 2104, a researcher trained in the application of the Home Visit Checklist observed home visits in all seven programs ( 40 home visits in total, at least five visits and between two to six unique home visitors per program, see Table 1 for details).

\subsection{Instrument}

The instrument used in this study is based on a checklist developed by the University of West Indies (UWI) to provide feedback to home visitors in Jamaica, Bangladesh and Colombia. The original checklist was revised and adapted by the authors for this study, in collaboration with UWI. 6 The Home Visit Checklist consists of 31 items, covering the following sections:

1. Basic information: date, location, duration of visit, child's age, child's sex, identification of primary caregiver.

2. Visit description: who participated (child, primary caregiver, other adults/children present)

3. Review of last visit: home visitor checks about play sessions between visits, caregiver demonstrates activities practiced.

\footnotetext{
${ }^{4}$ With the exception of the program in Bolivia, which is run by an NGO and only operates in one municipality and the one in Jamaica that is not at scale. See Berlinski and Shady (2015) for a description of programs in LAC

5 In Jamaica there is no current at-scale home visit program, the home visitors observed had participated in previous phases of home visit programs run by the University of the West Indies, in coordination with the Ministry of Health.

${ }^{6} \mathrm{UWI}$ has been one of the lead research partners involved in designing, implementing and evaluating home visit programs, mainly in Jamaica.
} 
4. Activities and methods: teaching (appropriate use of program manual, age appropriate activities, language emphasis), explanation and demonstration of activities for caregiver \& child, participation (review and feedback).

5. Relationship home visitor/caregiver: how well home visitor listens, responds, encourages, and gives positive/constructive feedback to home visitor, quality of the overall relationship between home visitor and caregiver.

6. Relationship home visitor/child: how well home visitor responds \& encourages child, gives enough time to complete activities, emphasizes language throughout, overall relationship between home visitor and child.

7. Overall visit participation \& environment: whether or not child \& caregiver actively participated, home visitor's overall effort to promote participation, overall atmosphere

The instrument also measures the home visitor's preparation for the visit and whether or not the materials and activities used are age appropriate, and, for child development programs, the degree to which the home visitor promotes language development throughout the visit, given that language development is one of the most important areas for school readiness and also one of the areas in which socioeconomic achievement gaps are largest in LAC (Schady, et al., 2015). Each item is scored on a Likert type scale.

In addition to the checklist, information on program structure, experience, and design was collected through a questionnaire applied to program coordinators/directors in each country (frequency of visits, home visitor's profile and compensation, supervision/monitoring/training structure, curriculum design, number of years/months of execution). These qualitative data, along with the information gleaned through informal interviews with program coordinators and observations throughout the visits serve to put the quantitative data collected through the Home Visit Checklist in context and are essential to the interpretation of the Checklist data.

For the nutrition programs, the Home Visit Checklist was modified to include information on how the anthropometric measures (children's weight) were conducted, if applicable, and the quality of the nutrition/feeding practices discussed. Checklist items referring to the games and activities implemented during the visit and the quality of the relationship between the home visitor and the child were not included in the nutrition checklist, since the nutrition programs are directed at the mother/primary caregiver, and do not include activities for the child. Both checklists can be found in Appendix 1.

\subsection{Training and inter-rater reliability}

The training in the Home Visit Checklist tool consisted of 4 days of tool revision, piloting, interrater reliability checks and tool re-revision led by Dr. Christine Powell of the University of West Indies. The first and second day of training began with a revision of the theory and evidence guiding the development and use of the Home Visit Checklist (in particular, for example, the importance of assessing the quality of the interactions between the home visitor and caregiver, and the logic behind individual items, such as whether or not the home visitor gave the caregiver 
time to practice the activities from the previous visit). This was followed by a detailed revision of the scoring for each item, with specific examples and case studies.

The third and fourth days of training were dedicated to piloting and inter-rater reliability checks. In total, five home visits, conducted by four different home visitors, were observed, three with boy children and two with girl children, aged 6 months to 4 years old. The homes visited were located in three low-income areas in and around Kingston: one urban site and two peri-urban sites. The home visitors observed had a range of qualifications and work experience. Following the piloting in the morning, the afternoon sessions of days three and four consisted of an inter-rater reliability (IRR) check between the researcher and Dr. Powell and a qualitative review of application and scoring, item-by-item. Inter-rater reliability was high - above .80 for the first two visits and above 0.90 for the last three visits. All inconsistencies in scoring were addressed and slight modifications in the checklist items were made.

\subsection{Scoring}

To minimize interruption and ensure that home visitors and families conducted as "natural" a visit as possible, the researcher filled out the checklist in private immediately after each visit concluded, rather than during the visit itself. To calculate the score for each item, a value was assigned to each possible answer, such that: Not observed/Never $=1$, Inadequate/Almost never $=2$, Adequate/Some of the time $=3 \& \mathrm{Good} /$ Most of the time $=4$. Thus, the score for each item ranges from 1 to 4 , with 1 being an exceptionally poor performance and 4 being a "good" performance ${ }^{7}$.

\subsection{Methodological Limitations}

The main limitations of this study are the small sample size (five to seven visits per program), and the fact that each community, home visitor, and family included in the study were hand-selected by program coordinators in each country. Thus the sample is by no means representative of the overall quality of home visits in each program. Furthermore, the programs vary greatly in terms of the number of years/months of implementation, coverage, and structure. In light of these considerations, the Checklist data do not serve to determine the program with best overall quality of visits, given the significant structural differences among programs. Rather, these data provide an individual "snap-shot" of each program, describing how home visitors and families interact in home visits, and identifying strengths and weaknesses in terms of each program's capacity to promote healthy caregiving practices. The information collected from program coordinators through the questionnaire contributes to an understanding of how program design mechanisms such as home visitor remuneration and training, supervision and monitoring relate to visit quality. This information is vital for policy makers interested in expanding or improving home visit parenting programs.

\footnotetext{
${ }^{7}$ The responses to some items do not all follow the "Non-existent/Never" pattern (for example, the possible answers for the last item in the checklist are: uncomfortable, neutral, happy/comfortable, and very happy). Regardless, for all items the range of possible values is 1 (worst) to 4 (best).
} 
In spite of all efforts to ensure that home visitors and families were comfortable with the research study, the visits observed were not necessarily "natural." The presence of the researcher, along with program coordinators and additional program staff in some cases, inevitably made home visitors and families nervous, thereby potentially limiting visit quality (or improving visit quality, if home visitors were inspired to put on a show for the visitors). In addition, in some cases program coordinators interrupted during the visit to give tips to the home visitors (reminding the home visitor to encourage the caregiver's participation, for example).

In the field, a few items from the instrument were found to be superficial measurements of the quality of participation and coaching of parents. See Appendix 3 for proposed revisions to the Check-list instrument. Similarly, the Home Visit Checklist has not been validated in relation to child development outcomes (predictive validity). That is, we do not know whether good performance in this instrument predicts better child development.

In addition, the interpretation of score values is not necessarily standardized across all items (for example, a score of a 3 (meaning "adequate") is perfectly acceptable for items such as "home visitor's demonstration of the activity," whereas a score of 3 ("some of the time") is much less than ideal for items such as "home visitor was responsive to the caregiver."

A final minor limitation is the fact that some visits were conducted in languages that the observer does not speak (Portuguese in Brazil, Awajún and Quechua in Peru, Kuna in Panama, and, to a limited extent, Aymara in Bolivia). However, the majority of the checklist items can be completed based on observation (body language, tone, activities developed), and items that require more than observation were not evaluated when necessary (for example, description of the quality of the explanation the visitor provides to the caregiver). When the visit was conducted entirely in indigenous language (Amazons in Peru, Kuna Yala islands in Panama), the program coordinator (or other program staff present during data collection) reviewed and interpreted what happened in each visit with the researcher after each visit (topics the home visitor covered, questions the home visitor asked).

\section{Context: overview of the seven programs in this study}

In Latin America, parenting programs usually vary in terms of:

1. Delivery model (e.g., home visits for individual households, or group sessions in a home, community or health center);

2. Presence of children during sessions;

3. Frequency of sessions (e.g., weekly, bi-weekly or even monthly);

4. Duration of sessions (e.g., one or two hours);

5. Type of activities (e.g., structured curriculum vs. unstructured one);

6. Type of materials (e.g., homemade, bought by the program). 
The way these features are combined depends on the objectives of the program and on the context where the intervention occurs. In addition, scale, budget constraints, human resource availability, and the differing curricular demands across programs require that, in some cases, the home visitor or group facilitator that interacts with the family is a paraprofessional (like the community health workers in the Brazilian PIM), while in others it is a community member (such as the Cuna más in Peru and PAIPPI in Nicaragua) trained and supervised by the program. As opposed to parenting programs in developed countries, programs in LAC have been more focused on the children and less on the caregiver.

The region has two types of home visiting-based parenting programs:

1. Programs focused on affecting nutritional outcomes:

- Exist in almost all LAC countries in some form and were originally conceived to reduce undernutrition.

- Are frequently administered on a monthly basis, and generally staffed by community members with minimal formal education.

- Usually provide caregivers with printed material to engage the subject of the intervention in specific activities. In particular, staff weigh the child and based on the result of this assessment provide nutritional counselling.

2. Programs focused on affecting early care, stimulation, and developmental outcomes ${ }^{8}$ :

- Are a more recent initiative and have more limited coverage in LAC.

- Are often administered on a weekly basis. Some programs employ better educated staff with relevant experience, fluency in local languages, and familiarity with local context and customs.

- Usually have an emphasis on the facilitator's interactions with the caregiver.

As can be seen in Table A2.1, all programs target the most vulnerable populations in the region using some ad hoc or national targeting method. The coverage of these programs varies significantly. $\mathrm{CNH}$ in Ecuador is by far the largest programs ( 356,400 children), followed by PIM in Brazil, PAIPPI in Nicaragua and Cuna Más in Peru ( 40,000 children). The operating costs of these programs vary too, reflecting differences in substantive operational aspects such as the frequency of the home visits and staffing decisions. For instance, Table A2.3 shows that employment conditions in these programs are mostly poor: Only $\mathrm{CNH}$ and PIM pay minimum wages to their home visitors, and the remaining programs offer visitors a modest stipend.

\footnotetext{
${ }^{8}$ Programs focused on affecting early care and stimulation particularly through home visits have started only recently in LAC. For example, the newest child development national programs Cunamás (Perú) and Amor para los Más Chiquitos (Nicaragua) were launched in 2013. In contrast, there is a long history in the region of programs designed to improve child nutrition because this has been the main risk factor for child development identified and prioritized by policy makers.
} 
A more detailed overview of the seven programs included in this study can be found in Tables A2.1 (targeting strategies and issues of coverage and costs), A2.2 (design features of the interventions) and A2.3 (home visitor's characteristic) in Appendix $2 .{ }^{9}$

\section{Overall results}

\subsection{Sample Basic Statistics}

The following tables describe the number of visits observed, average visit duration, and average age of the child per program, as well as whether the child and caregiver participated ${ }^{10}$.

Table 1: Child Development Programs Sample: Basic Statistics

\begin{tabular}{|l|c|c|c|c|c|c|}
\hline & \multicolumn{3}{|c|}{$\begin{array}{c}\text { Number of visits } \\
\text { observed }\end{array}$} & $\begin{array}{c}\text { Duration } \\
\text { visit } \\
\text { (minutes) }\end{array}$ & $\begin{array}{c}\text { Child's age } \\
\text { (months) }\end{array}$ & $\begin{array}{c}\text { Child and } \\
\text { caregiver } \\
\text { participated } \\
\text { (*) }\end{array}$ \\
\cline { 2 - 7 } & Total & Girls & Boys & & 26.5 & 6 \\
\hline Jamaica-HV & 6 & 5 & 1 & 42.5 & 16.6 & 5 \\
\hline Brazil-PIM & 5 & 2 & 3 & 46 & 25.5 & 7 \\
\hline Peru-Cuna Más & 7 & 6 & 1 & 56.4 & 21.5 & 6 \\
\hline Nicaragua- PAIPPI & 6 & 5 & 1 & 45 & 16.2 & 5 \\
\hline Ecuador-CNH & 5 & 1 & 4 & 40 & & 5 \\
\hline
\end{tabular}

${ }^{*}$ ) In all cases the principal caregiver was the mother. Also, in Peru, there were 2 visits in which caregiver and father participated, while in Nicaragua, in 1 visit both caregiver and father participated

Table 2: Nutrition Programs Sample: Basic Statistics

\begin{tabular}{|l|c|c|c|c|c|c|c|}
\hline & \multicolumn{4}{|c|}{$\begin{array}{c}\text { Number of visits } \\
\text { observed }\end{array}$} & $\begin{array}{c}\text { Duration } \\
\text { of visit } \\
\text { (minutes) }\end{array}$ & $\begin{array}{c}\text { Child's } \\
\text { age } \\
\text { (months) }\end{array}$ & $\begin{array}{c}\text { Child and } \\
\text { caregiver } \\
\text { participated } \\
\text { (*) }\end{array}$ \\
\hline \begin{tabular}{l|c|c|c|c|c|c|c|} 
Bolivia - \\
CSRA
\end{tabular} & 6 & 3 & 2 & 1 & 41 & 8.4 & $\begin{array}{c}4 \text { children } \\
\text { and } \\
1 \text { caregiver }\end{array}$ \\
\hline $\begin{array}{l}\text { Panama - } \\
\text { AIN-C }\end{array}$ & 5 & 3 & 2 & 0 & 18 & 9.4 & 5 \\
\hline
\end{tabular}

$\left(^{\star}\right)$ In Panama, all caregivers were the mother, while in Bolivia only one caregiver was the mother.

\footnotetext{
${ }^{9}$ A full description of the parenting programs listed in Tables A.21-A.2.3 can be found in Araujo, López Bóo and Puyana (2013)

${ }^{10}$ In general, home visitors should work with beneficiary families to schedule visits when both the caregiver and the child can participate.
} 


\subsection{Findings: Child development programs}

Results from the checklist are analyzed two ways: First, we present the distribution of scores (number of observations and percent per answer, per item), as described in Tables 3 and 4 for the full sample, and then in Section $V$ for each country separately. Second, we analyze the overall score for each item, as presented in the Figures 1 and 2 below.

Table 3 presents the overall distribution of results for the five child development programs visited. The main strength of the visits observed is the positive relationship home visitors have with families. Caregivers and children are happy to see the visitor, and the visitor behaves respectfully with families, acknowledging that he/she is a guest at their house. Often the children come running to greet the educator and eagerly await the visit's activities. The overwhelming majority of the visitors are warm, patient, and supportive with children. They consistently praise and encourage them. In many cases, we observed that (appropriately) the caregiver and the child practice the activities together throughout the visit, rather than the home visitor doing the activities with the child, while the caregiver observes. Another strength is that most of the activities conducted during the visits are age-appropriate.

A successful visit requires the home visitor to: revise the content of previous activities ${ }^{11}$, emphasize language development throughout the session, explain the developmental objective of the activities to the caregiver, and suitably demonstrate them. Unfortunately, a large majority of the observed visitors fail to achieve these objectives. Less than half of visitors devote appropriate time to reviewing the past week's activities verbally, and less than a third encourage the caregiver to elaborate or demonstrate with the child the activities they had practiced since last visit. Despite visitors being good at mentioning to caregivers the importance of reading or looking at books with their child and naming objects in the household, just half of them explain developmental activities for the caregiver, and only one third emphasized language development throughout the visit. Only one quarter of the visitors suitably demonstrated activities to the child.

Furthermore, although the interactions with the family are very amicable, the content and approaches used by visitors are not always as envisioned by program designers. For example, most visitors ask caregivers if they have any questions or opinions at least once or twice throughout the visit. However, this rarely serves to achieve meaningful participation, given that most mothers respond "no," and the visitor makes no further effort to encourage the caregiver to actively engage not only through modeling/practicing the activities, but also through discussing her child's development and voicing her reflections, observations, suggestions, doubts or concerns. Likewise, while visitors are very quick to praise the children for every activity attempted or completed in the majority of the visits, only a third of them provide positive reinforcement or feedback to caregivers.

\footnotetext{
${ }^{11}$ Home visit programs are designed to reinforce behaviors by encouraging caregivers to practice the activities with their children in between visits. The five child development programs visited in this study include training for the home visitors on the need to ask caregivers to describe and to demonstrate the activities they did with their children throughout the week.
} 
Table 3: Child Development Programs: Score distribution per item

\begin{tabular}{|c|c|c|c|c|c|c|c|c|}
\hline Description of activity & \multicolumn{8}{|c|}{ Overall score distribution ${ }^{12}$} \\
\hline \multicolumn{9}{|c|}{ Review of activities done since last visit } \\
\hline & \multicolumn{2}{|c|}{ Not observed } & \multicolumn{2}{|c|}{ Inadequate } & \multicolumn{2}{|c|}{ Adequate } & \multicolumn{2}{|c|}{ Good } \\
\hline & $\mathrm{N}$ & $\%$ & $\mathrm{~N}$ & $\%$ & $\mathrm{~N}$ & $\%$ & $\mathrm{~N}$ & $\%$ \\
\hline $\begin{array}{l}\text { Home visitor (HV) asks caregiver } \\
\text { about play sessions between visits }\end{array}$ & 4 & $13.8 \%$ & 1 & $3.5 \%$ & 6 & $20.7 \%$ & 13 & $44.8 \%$ \\
\hline $\begin{array}{l}\text { HV asks caregiver to demonstrate } \\
\text { w/child what had been done since last } \\
\text { visit }\end{array}$ & 8 & $27.6 \%$ & 2 & $6.9 \%$ & 5 & $17.2 \%$ & 9 & $31.0 \%$ \\
\hline \multicolumn{9}{|c|}{$\begin{array}{ll} & \text { Activities and methods: teaching } \\
\end{array}$} \\
\hline & \multicolumn{2}{|c|}{ Not observed } & \multicolumn{2}{|c|}{ Inadequate } & \multicolumn{2}{|c|}{ Adequate } & \multicolumn{2}{|c|}{ Good } \\
\hline & $\mathrm{N}$ & $\%$ & $\mathrm{~N}$ & $\%$ & $\mathrm{~N}$ & $\%$ & $\mathrm{~N}$ & $\%$ \\
\hline $\begin{array}{l}\text { HV uses the program educational } \\
\text { material } \\
\text { (manual/booklet) }\end{array}$ & 1 & $3.5 \%$ & 2 & $6.9 \%$ & 9 & $31.0 \%$ & 5 & $17.2 \%$ \\
\hline HV prepared for the visit in advance & 3 & $10.3 \%$ & 3 & $10.3 \%$ & 3 & $10.3 \%$ & 20 & $69 \%$ \\
\hline $\begin{array}{l}\mathrm{HV} \text { demonstrates age-appropriate } \\
\text { activities and materials }\end{array}$ & 1 & $3.5 \%$ & 1 & $3.5 \%$ & 5 & $17.2 \%$ & 22 & $75.8 \%$ \\
\hline $\begin{array}{l}\mathrm{HV} \text { emphasizes language } \\
\text { development throughout the visit }\end{array}$ & 4 & $13.8 \%$ & 4 & $13.8 \%$ & 11 & $37.9 \%$ & 10 & $34.5 \%$ \\
\hline \multicolumn{9}{|c|}{ Activities and methods: explanation and demonstration } \\
\hline & \multicolumn{2}{|c|}{ Not observed } & \multicolumn{2}{|c|}{ Inadequate } & \multicolumn{2}{|c|}{ Adequate } & \multicolumn{2}{|c|}{ Good } \\
\hline & $\mathrm{N}$ & $\%$ & $\mathrm{~N}$ & $\%$ & $\mathrm{~N}$ & $\%$ & $\mathrm{~N}$ & $\%$ \\
\hline $\begin{array}{l}\text { HV's verbal explanation of activities to } \\
\text { the caregiver }\end{array}$ & 4 & $14.8 \%$ & 5 & $18.5 \%$ & 4 & $14.8 \%$ & 14 & $51.8 \%$ \\
\hline $\begin{array}{l}\text { HV's demonstration of activities to the } \\
\text { caregiver }\end{array}$ & 3 & $10.3 \%$ & 1 & $3.5 \%$ & 7 & $24.1 \%$ & 18 & $62.1 \%$ \\
\hline $\begin{array}{l}\text { HV's verbal explanation of activities to } \\
\text { the child }\end{array}$ & 2 & $6.9 \%$ & 2 & $6.9 \%$ & 14 & $48.3 \%$ & 11 & $37.9 \%$ \\
\hline $\begin{array}{l}\text { HV's demonstration of activities to the } \\
\text { child }\end{array}$ & 2 & $6.9 \%$ & 3 & $10.3 \%$ & 16 & $55.2 \%$ & 8 & $27.6 \%$ \\
\hline \multicolumn{9}{|c|}{ Activities and methods: participation } \\
\hline & \multicolumn{2}{|c|}{ Never } & \multicolumn{2}{|c|}{ Almost never } & \multicolumn{2}{|c|}{$\begin{array}{l}\text { Some of the } \\
\text { time }\end{array}$} & \multicolumn{2}{|c|}{$\begin{array}{l}\text { Most of the } \\
\text { time }\end{array}$} \\
\hline & $\mathrm{N}$ & $\%$ & $\mathrm{~N}$ & $\%$ & $\mathrm{~N}$ & $\%$ & $\mathrm{~N}$ & $\%$ \\
\hline $\begin{array}{l}\text { HV asks caregiver to practice } \\
\text { activities with child }\end{array}$ & 1 & $3.5 \%$ & 2 & $6.9 \%$ & 6 & $20.7 \%$ & 20 & $69 \%$ \\
\hline $\begin{array}{l}\text { HV reviews activities with caregiver at } \\
\text { end of visit and agreed on which } \\
\text { activities caregiver would practice } \\
\text { between visits }\end{array}$ & 2 & $6.9 \%$ & 4 & $13.8 \%$ & 6 & $20.7 \%$ & 17 & $58.6 \%$ \\
\hline
\end{tabular}

\footnotetext{
12 Table does not include "non-applicable" thus not all rows add up to $100 \%$, and total N varies by item.
} 


\begin{tabular}{|c|c|c|c|c|c|c|c|c|}
\hline \multicolumn{9}{|c|}{ Relationship between HV and caregiver } \\
\hline & \multicolumn{2}{|c|}{ Never } & \multicolumn{2}{|c|}{$\begin{array}{c}\text { Almost } \\
\text { never }\end{array}$} & \multicolumn{2}{|c|}{$\begin{array}{l}\text { Some of the } \\
\text { time }\end{array}$} & \multicolumn{2}{|c|}{$\begin{array}{l}\text { Most of the } \\
\text { time }\end{array}$} \\
\hline & $\mathrm{N}$ & $\%$ & $\mathrm{~N}$ & $\%$ & $\mathrm{~N}$ & $\%$ & $\mathrm{~N}$ & $\%$ \\
\hline HV listens to caregiver & 0 & $0 \%$ & 0 & $0 \%$ & 3 & $10.3 \%$ & 26 & $89.7 \%$ \\
\hline $\mathrm{HV}$ is responsive to caregiver & 0 & $0 \%$ & 1 & $3.5 \%$ & 6 & $20.7 \%$ & 22 & $75.9 \%$ \\
\hline $\begin{array}{l}\text { HV asks caregiver's opinion /asked } \\
\text { for questions throughout the visit }\end{array}$ & 3 & $10.3 \%$ & 6 & $20.7 \%$ & 9 & $31 \%$ & 11 & $37.9 \%$ \\
\hline $\begin{array}{l}\mathrm{HV} \text { encourages and positively } \\
\text { reinforces the caregiver }\end{array}$ & 1 & $3.5 \%$ & 7 & $24.1 \%$ & 10 & $34.5 \%$ & 11 & $37.9 \%$ \\
\hline $\begin{array}{l}\text { Overall relationship between HV and } \\
\text { caregiver is warm and supportive }\end{array}$ & 0 & $0 \%$ & 1 & $3.5 \%$ & 2 & $6.9 \%$ & 26 & $89.7 \%$ \\
\hline \multicolumn{9}{|c|}{ Relationship between HV and child } \\
\hline & \multicolumn{2}{|c|}{ Never } & \multicolumn{2}{|c|}{$\begin{array}{c}\text { Almost } \\
\text { never }\end{array}$} & \multicolumn{2}{|c|}{$\begin{array}{l}\text { Some of the } \\
\text { time }\end{array}$} & \multicolumn{2}{|c|}{$\begin{array}{l}\text { Most of the } \\
\text { time }\end{array}$} \\
\hline & $\mathrm{N}$ & $\%$ & $\mathrm{~N}$ & $\%$ & $\mathrm{~N}$ & $\%$ & $\mathrm{~N}$ & $\%$ \\
\hline $\begin{array}{l}\text { HV listens to child and responded to } \\
\text { his/her vocalizations/gestures }\end{array}$ & 0 & $0 \%$ & 2 & $6.9 \%$ & 4 & $13.8 \%$ & 23 & $79.3 \%$ \\
\hline $\begin{array}{l}\text { HV praises child when he/she } \\
\text { attempts/completes an activity }\end{array}$ & 0 & $0 \%$ & 2 & $6.9 \%$ & 7 & $24.1 \%$ & 20 & $69 \%$ \\
\hline $\begin{array}{l}\text { HV talks about the activities the child } \\
\text { does throughout the visit, or talks to } \\
\text { the child while the child does the } \\
\text { activities }\end{array}$ & 3 & $10.3 \%$ & 8 & $27.6 \%$ & 6 & $20.7 \%$ & 12 & $41.8 \%$ \\
\hline $\begin{array}{l}\text { HV gives the child enough time to } \\
\text { explore materials and complete } \\
\text { activities }\end{array}$ & 1 & $3.5 \%$ & 1 & $3.5 \%$ & 4 & $13.8 \%$ & 23 & $79.3 \%$ \\
\hline $\begin{array}{l}\text { Overall relationship between HV and } \\
\text { child is warm and supportive }\end{array}$ & 0 & $0 \%$ & 2 & $6.9 \%$ & 1 & $3.5 \%$ & 26 & $89.7 \%$ \\
\hline \multicolumn{9}{|c|}{ Overall participation and atmosphere } \\
\hline & \multicolumn{2}{|c|}{ Never } & \multicolumn{2}{|c|}{ Almost never } & \multicolumn{2}{|c|}{$\begin{array}{l}\text { Some of the } \\
\text { time }\end{array}$} & \multicolumn{2}{|c|}{$\begin{array}{c}\text { Most of the } \\
\text { time }\end{array}$} \\
\hline & $\mathrm{N}$ & $\%$ & $\mathrm{~N}$ & $\%$ & $\mathrm{~N}$ & $\%$ & $\mathrm{~N}$ & $\%$ \\
\hline Child actively participates & 0 & $0 \%$ & 3 & $10 \%$ & 2 & $6.9 \%$ & 24 & $\begin{array}{c}82.8 \\
\%\end{array}$ \\
\hline Caregiver actively participates & 0 & $0 \%$ & 3 & $10.3 \%$ & 11 & $37.9 \%$ & 15 & $\begin{array}{c}51.7 \\
\%\end{array}$ \\
\hline $\begin{array}{l}\text { HV makes a significant effort to } \\
\text { encourage participation }\end{array}$ & 3 & $10.3 \%$ & 0 & 0 & 10 & $34.5 \%$ & 16 & $\begin{array}{c}55.2 \\
\%\end{array}$ \\
\hline \multirow{2}{*}{$\begin{array}{l}\text { Overall atmosphere of the visit is } \\
\text { collaborative and supportive }\end{array}$} & \multicolumn{2}{|c|}{ Uncomfortable } & \multicolumn{2}{|c|}{ Neutral } & \multicolumn{2}{|c|}{$\begin{array}{c}\text { Happy / } \\
\text { comfortable }\end{array}$} & \multicolumn{2}{|c|}{ Very happy } \\
\hline & 1 & $3.5 \%$ & 1 & $3.5 \%$ & 20 & $69 \%$ & 7 & $\begin{array}{c}24.1 \\
\%\end{array}$ \\
\hline
\end{tabular}


The distribution of scores as presented in the table above provides a description of the overall performance on each item. The total score, however, allows for a visual representation of the scores. We thus present total scores by module of the Checklist in Figures 1 and 2 below.

The analysis of scores below shows that average scores across programs never go beyond an "adequate" score of 3 points; with many items (demonstration of activities, promotion of language development and encouragement of language development through the visit) being below that threshold consistently. ${ }^{13}$

\section{Figure 1: Child Development Programs: Average score per item, all programs}

\section{Review of activities done since last visit}

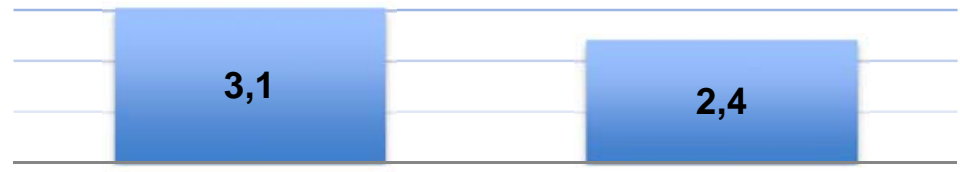

HV asks caregiver about activities practiced during the week

HV asks caregiver to demonstrate activities practiced

Activities \& methods: Teaching

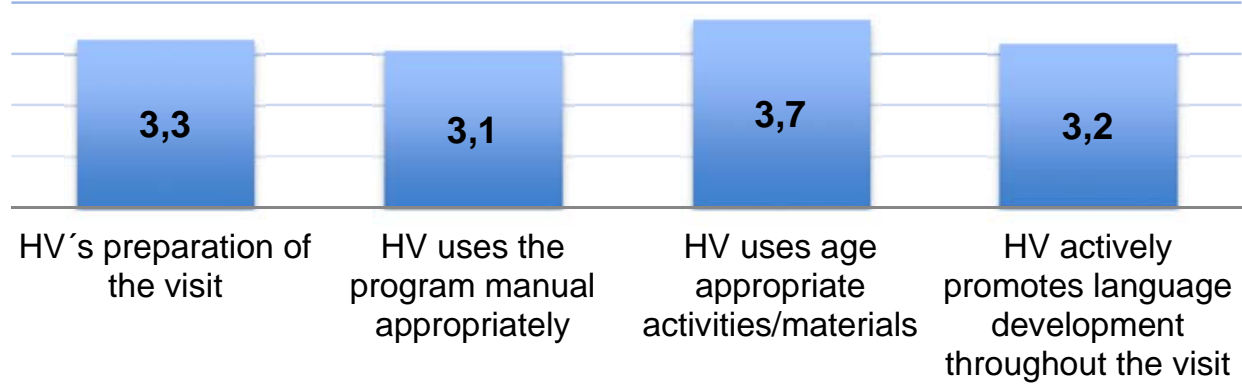

\footnotetext{
${ }^{13}$ To calculate the score for each item, a value was assigned to each possible answer, such that: Non-existent/Never $=1$, Inadequate/Almost never $=2$, Adequate/Some of the time $=3$, Good/ Most of the time $=4$, Very good/always $=5$. Thus, the score range for each item ranges from 1 to 5 , with 1 being an exceptionally poor performance and 5 being a very good performance.
} 


\section{Activities \& teaching: Explanation \& demonstration}

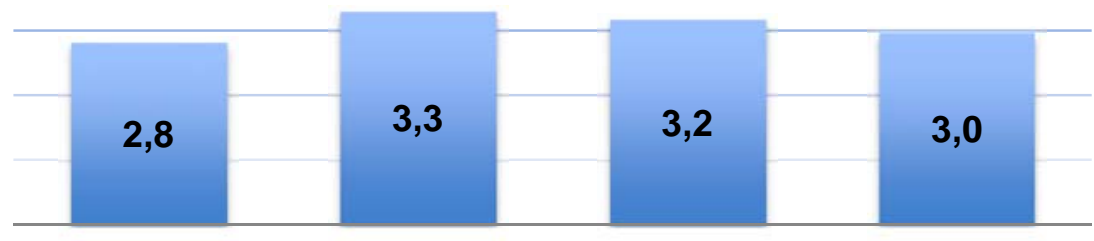

Explanation of Demonstration of Explication of Demonstration of activities for the activities for the activities for the activities for the
caregiver
caregiver
child
child

Activities \& methods: Participation

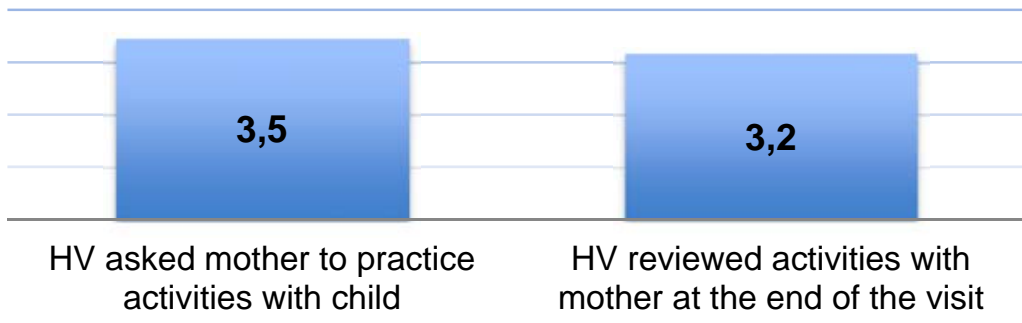

\section{Relationship HV - Caregiver}

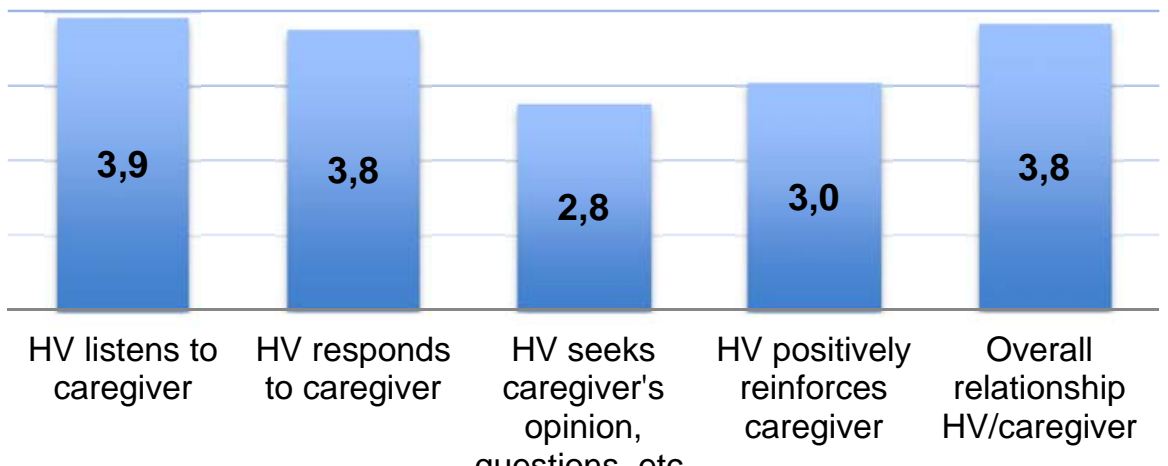
questions, etc. 


\section{Relationship HV - Child}

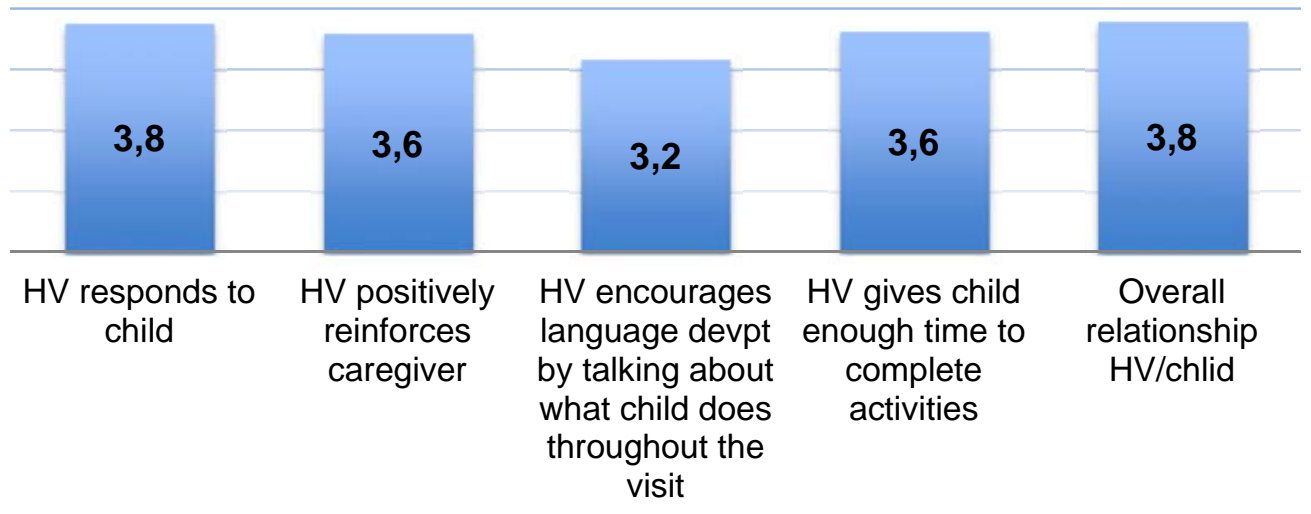

Overall visit participation \& environment

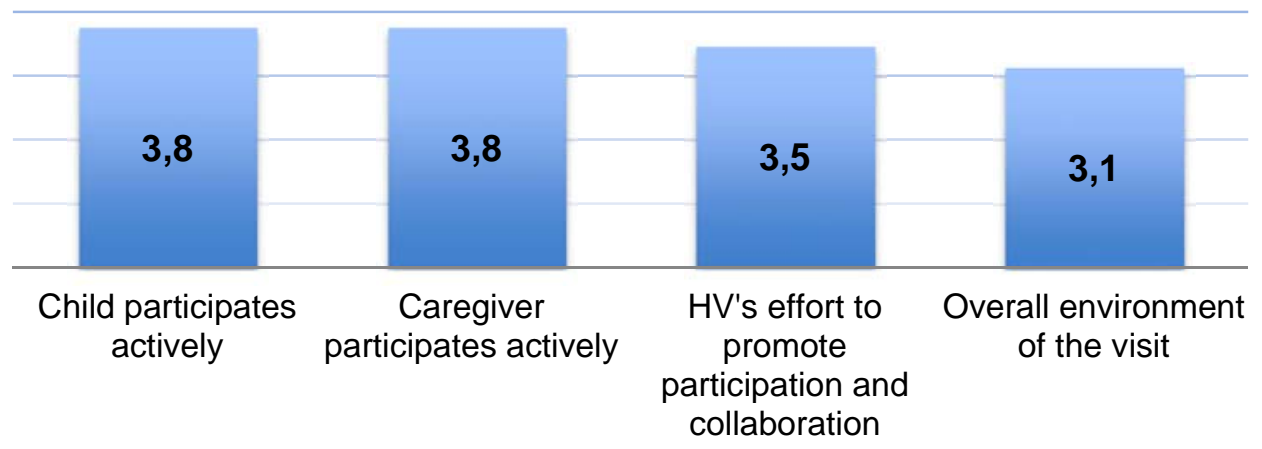

When looking at scores per program (not reported), there is a clear heterogeneity among countries, with PIM in Brazil achieving the highest scores across most items. This variation most likely reflects structural differences, such as program size, monitoring, supervision, support and training system and whether home visitors receive a salary or a stipend, among other factors, not to mention the length of time a program has been in operation. In Nicaragua, for example, PAIPPI had only been in implementation for 6 months at the time it was observed, while PIM in Brazil has over 10 years of experience. Moreover, PIM home visitors receive a salary, extensive training, and consistent (weekly) individualized monitoring and support. Section 5 provides more information about each program's structure and design that serve to explain these variations.

It is interesting to note, however, that differences in scores are not completely explained by structural factors. For example, the program $\mathrm{CNH}$ in Ecuador received notably high scores in most items, despite the fact that their visitors have an exceptionally high workload: each $\mathrm{CNH}$ educator visits at least 30 to 40 families per week (and attends an additional 30 to 40 families through group visits, for a total of 80 families), while visitors in other programs visit around 10 to 15 families. 


\subsection{Findings: Nutrition program}

In the two nutrition programs observed, the following aspects stand out as strengths: first, as in the child development programs, home visitors have a supportive, respectful relationship with the mother/caregiver. Second, their use of program materials is particularly strong: in the CRSA program in Bolivia, home visitors put on interactive puppet shows for caregivers and reinforce the behavior change messages through the use of poster boards and pictures. It is encouraging that observations from the low-resource setting of the CSRA in Bolivia showed that ludic and participatory methodologies (e.g. puppets and actors) used to communicate behavioral change messages resulted in high scores in the quality of interaction between the educator, the mother and the child. In AIN-C in Panama, home visitors use printouts with images and a few words to discuss feeding practices with the caregiver, and also employ several tactics to engage the caregiver with the material, for example asking her to point at the image that represents a feeding practice she will implement during the following week. Third, at the end of each visit, home visitors discuss the topics covered with the caregiver and help her to select which feeding practices she will implement in the following week.

The programs could improve in the two following areas, however: first, most home visitors start the visit by asking if the child has been eating well and whether or not he/she is in overall good health, but do not ask about whether or not the caregiver has implemented the feeding practices discussed in the previous visit. Second, although home visitors make a concerted effort to encourage the caregiver's participation they could do more to encourage caregivers to talk during the visit (voice their concerns, observations, etc.) and to help caregivers plan not just which improved feeding practices to implement but how they will implement these changes.

Table 4: Nutrition programs: Score distribution per item

\begin{tabular}{|c|c|c|c|c|c|c|c|c|}
\hline Description of activity & \multicolumn{8}{|c|}{ Overall score distribution $^{14}$} \\
\hline \multicolumn{9}{|c|}{ Review of activities done since last visit } \\
\hline & \multicolumn{2}{|c|}{$\begin{array}{c}\text { Not } \\
\text { observed }\end{array}$} & \multicolumn{2}{|c|}{ Inadequate } & \multicolumn{2}{|c|}{ Adequate } & \multicolumn{2}{|c|}{ Good } \\
\hline & $\mathrm{N}$ & $\%$ & $\mathrm{~N}$ & $\%$ & $\mathrm{~N}$ & $\%$ & $\mathrm{~N}$ & $\%$ \\
\hline $\begin{array}{l}\text { HV followed up with caregiver about } \\
\text { feeding practice discussed during the } \\
\text { previous visit }\end{array}$ & 5 & $45.5 \%$ & 1 & $9.1 \%$ & 3 & $27.3 \%$ & 1 & $9.1 \%$ \\
\hline \multicolumn{9}{|c|}{ Activities and methods: Teaching \& participation } \\
\hline & \multicolumn{2}{|c|}{$\begin{array}{c}\text { None/not at } \\
\text { all }\end{array}$} & \multicolumn{2}{|c|}{ Inadequate } & \multicolumn{2}{|c|}{ Adequate } & \multicolumn{2}{|c|}{ Good } \\
\hline & $\mathrm{N}$ & $\%$ & $\mathrm{~N}$ & $\%$ & $\mathrm{~N}$ & $\%$ & $\mathrm{~N}$ & $\%$ \\
\hline $\begin{array}{l}\text { HV had prepared for the visit in } \\
\text { advance }\end{array}$ & 1 & $9.1 \%$ & 0 & $0 \%$ & 7 & $63.6 \%$ & 3 & $27.3 \%$ \\
\hline
\end{tabular}

14 Table does not include "non-applicable," thus not all rows add up to $100 \%$, and total N varies by item 


\begin{tabular}{|l|c|c|c|c|c|c|c|c|}
\hline $\begin{array}{l}\text { HV used the program educational } \\
\text { material } \\
\text { (manual/booklet/information sheets) }\end{array}$ & 0 & $0 \%$ & 1 & $9.1 \%$ & 5 & $45.5 \%$ & 5 & $45.5 \%$ \\
\hline $\begin{array}{l}\text { HV provided strong explanations and } \\
\text { motivations for healthy feeding } \\
\text { practices }\end{array}$ & 2 & $18.2 \%$ & 1 & $9.1 \%$ & 1 & $9.1 \%$ & 7 & $63.7 \%$ \\
\hline $\begin{array}{l}\text { HV reviewed feeding practices with } \\
\text { caregiver at end of visit and agreed on } \\
\text { which practices caregiver would focus } \\
\text { on between visits }\end{array}$ & 1 & $9.1 \%$ & 0 & $0 \%$ & 2 & $18.2 \%$ & 8 & $72.7 \%$ \\
\hline $\begin{array}{l}\text { Topics discussed were age } \\
\text { appropriate }\end{array}$ & 0 & $0 \%$ & 0 & $0 \%$ & 0 & $0 \%$ & 11 & $100 \%$ \\
\hline
\end{tabular}

\begin{tabular}{|l|c|c|c|c|c|c|c|c|}
\hline \multicolumn{7}{|c|}{ Relationship between HV and caregiver } \\
\hline & \multicolumn{2}{|c|}{ Never } & \multicolumn{2}{|c|}{$\begin{array}{c}\text { Almost } \\
\text { never }\end{array}$} & $\begin{array}{c}\text { Some of the } \\
\text { time }\end{array}$ & \multicolumn{2}{c|}{$\begin{array}{c}\text { Most of the } \\
\text { time }\end{array}$} \\
\cline { 2 - 12 } & $\mathrm{N}$ & $\%$ & $\mathrm{~N}$ & $\%$ & $\mathrm{~N}$ & $\%$ & $\mathrm{~N}$ & $\%$ \\
\hline HV listened to caregiver & 0 & $0 \%$ & 0 & $0 \%$ & 2 & $18.2 \%$ & & $81.8 \%$ \\
\hline HV was responsive to caregiver & 0 & $0 \%$ & 2 & $18.2 \%$ & 1 & $9.1 \%$ & 8 & $72.7 \%$ \\
\hline $\begin{array}{l}\text { HV asked caregiver's opinion lasked } \\
\text { for questions throughout the visit }\end{array}$ & 1 & $9.1 \%$ & 0 & $0 \%$ & 6 & $54.6 \%$ & 4 & $36.4 \%$ \\
\hline $\begin{array}{l}\text { HV encouraged and positively } \\
\text { reinforced the caregiver }\end{array}$ & 2 & $18.2 \%$ & 2 & $18.8 \%$ & 1 & $9.1 \%$ & 6 & $54.6 \%$ \\
\hline $\begin{array}{l}\text { Overall relationship between HV and } \\
\text { caregiver was warm and supportive }\end{array}$ & 1 & $9.1 \%$ & 0 & $0 \%$ & 2 & $18.2 \%$ & 8 & $72.7 \%$ \\
\hline \multicolumn{7}{|c|}{ Overall participation and atmosphere } \\
\hline
\end{tabular}


Figure 2: Nutrition programs: Score per item ${ }^{15}$

Activities \& teaching: Explanation \& demonstration

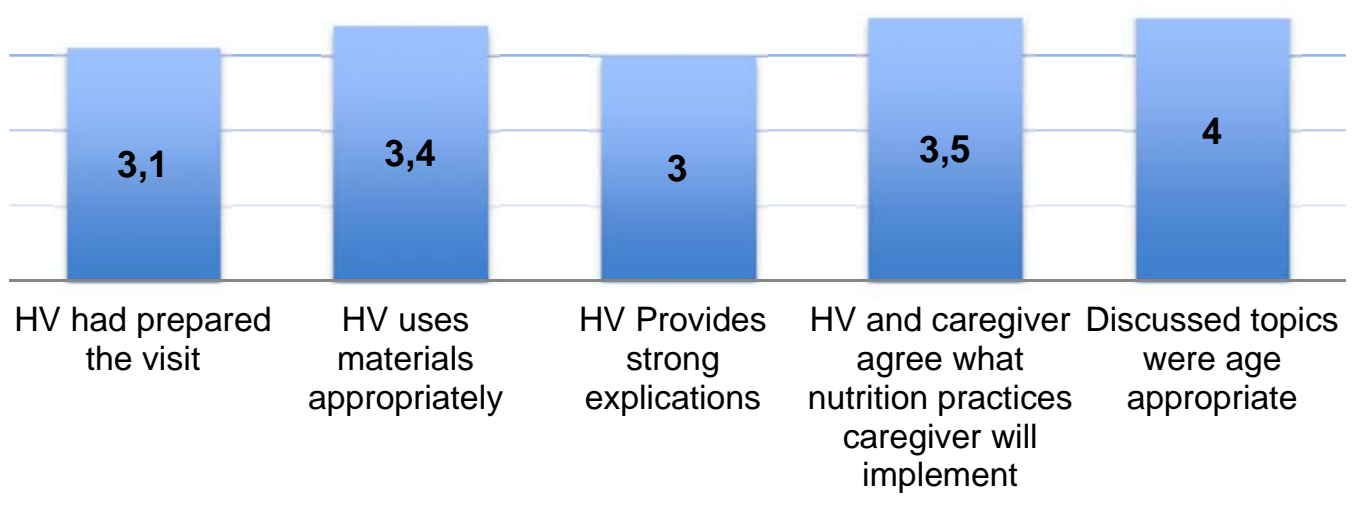

Relationship: HV - Caregiver

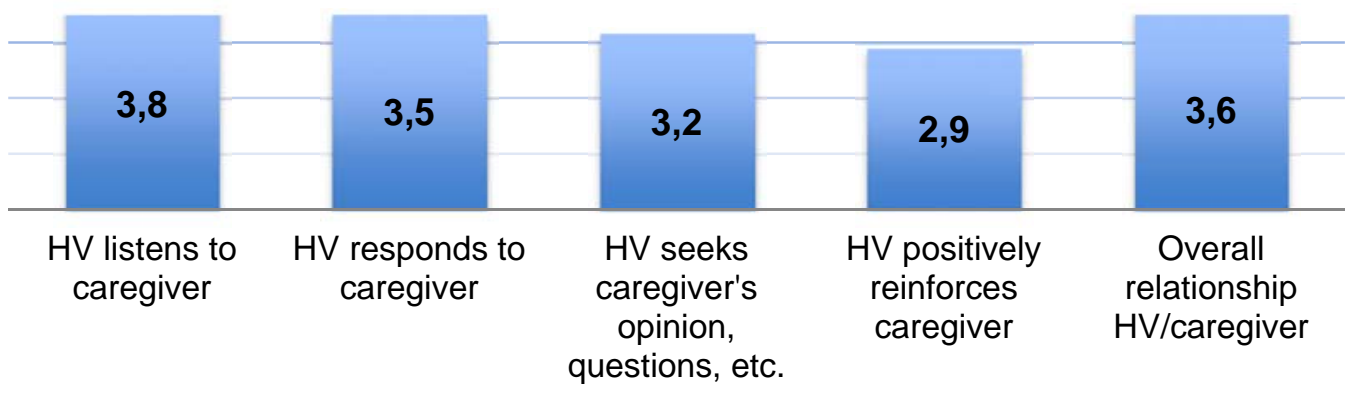

Overall participation \& environment

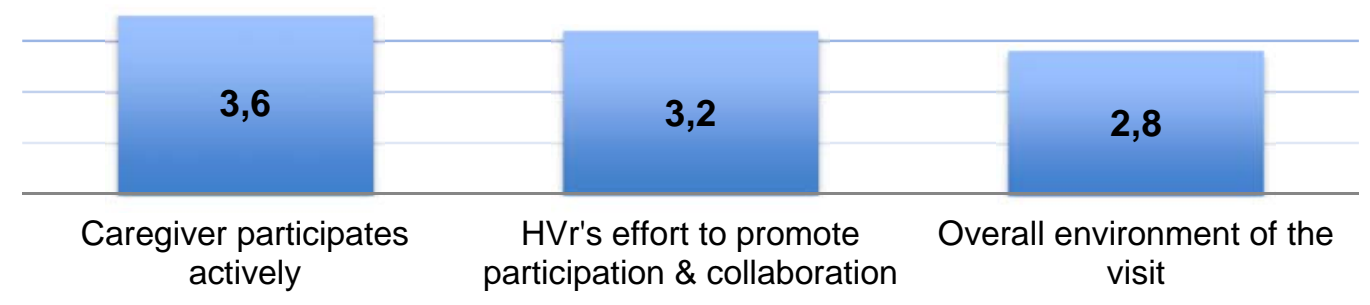

${ }^{15}$ In the review of activities since last visits, the average score is 2 . 


\section{Results by country}

\subsection{Jamaica: Home Visit Program}

As mentioned, at the time of data collection there was no home visit program currently in implementation in Jamaica. However, for the purposes of this study, the Child Development Research Group of the University of the West Indies organized visits with home visitors from a previous home visiting program that ran during 2011 to 2013 (Clinic-Based Program). Six different home visitors were observed, some with more than ten years of experience working as a home visitor in several different home visiting programs in Jamaica and some who only had worked only in the most recent program. Since the visits observed were not part of any current program, questions 4 and 5 of the Checklist instrument (referring to the review of the previous visit) do not apply. All visits took place in urban and semi-urban low-income areas in and around Kingston. Five of the six visits observed followed the appropriate methodology, while in one visit the teacher did not develop any activity or game with mother and child, rather, she just let the child play with toys she had brought and offered no explanation or feedback to the child or mother.

Overall, the Jamaican home visitors observed consistently emphasize language development throughout the visit, discussing with the caregiver at length the importance of talking to the child, even (or especially) while doing day to day activities or chores like bathing, cooking, and cleaning.

Table 5: Score distribution: Jamaica Home Visit Program

\begin{tabular}{|c|c|c|c|c|c|c|c|c|}
\hline Description of activity & \multicolumn{8}{|c|}{ Overall score distribution } \\
\hline \multicolumn{9}{|c|}{ Activities and methods: teaching } \\
\hline & \multicolumn{2}{|c|}{ Not observed } & \multicolumn{2}{|c|}{ Inadequate } & \multicolumn{2}{|c|}{ Adequate } & \multicolumn{2}{|c|}{ Good } \\
\hline & $\mathrm{N}$ & $\%$ & $\mathrm{~N}$ & $\%$ & $\mathrm{~N}$ & $\%$ & $\mathrm{~N}$ & $\%$ \\
\hline $\begin{array}{l}\text { HV used the program educational } \\
\text { material } \\
\text { (manual/booklet) }\end{array}$ & 1 & $16.7 \%$ & 0 & $0 \%$ & 3 & $50 \%$ & 2 & $33.3 \%$ \\
\hline $\begin{array}{l}\text { HV had prepared for the visit in } \\
\text { advance }\end{array}$ & 1 & $16.7 \%$ & 2 & $33.3 \%$ & 1 & $16.7 \%$ & 2 & $33.3 \%$ \\
\hline $\begin{array}{l}\text { HV demonstrated age-appropriate } \\
\text { activities and materials }\end{array}$ & 0 & $0 \%$ & 0 & $0 \%$ & 1 & $16.7 \%$ & 5 & $83.3 \%$ \\
\hline $\begin{array}{l}\text { HV emphasized on language } \\
\text { development throughout the visit }\end{array}$ & 0 & $0 \%$ & 1 & $16.7 \%$ & 3 & $50 \%$ & 2 & $33.3 \%$ \\
\hline \multicolumn{9}{|c|}{ Activities and methods: explanation and demonstration } \\
\hline & \multicolumn{2}{|c|}{ Not observed } & \multicolumn{2}{|c|}{ Inadequate } & \multicolumn{2}{|c|}{ Adequate } & \multicolumn{2}{|c|}{ Good } \\
\hline & $\mathrm{N}$ & $\%$ & $\mathrm{~N}$ & $\%$ & $\mathrm{~N}$ & $\%$ & $\mathrm{~N}$ & $\%$ \\
\hline
\end{tabular}




\begin{tabular}{|c|c|c|c|c|c|c|c|c|}
\hline $\begin{array}{l}\text { HV's verbal explanation of activities to } \\
\text { the caregiver }\end{array}$ & 1 & $16.7 \%$ & 1 & $16.7 \%$ & 0 & $0 \%$ & 4 & $66.7 \%$ \\
\hline $\begin{array}{l}\text { HV's demonstration of activities to the } \\
\text { caregiver }\end{array}$ & 1 & $16.7 \%$ & 0 & $0 \%$ & 3 & $50 \%$ & 2 & $33.3 \%$ \\
\hline $\begin{array}{l}\text { HV's verbal explanation of activities to } \\
\text { the child }\end{array}$ & 0 & $0 \%$ & 1 & $16.7 \%$ & 3 & $50 \%$ & 2 & $33.3 \%$ \\
\hline $\begin{array}{l}\text { HV's demonstration of activities to the } \\
\text { child }\end{array}$ & 0 & $0 \%$ & 1 & $16.7 \%$ & 4 & $66.7 \%$ & 1 & $16.7 \%$ \\
\hline \multicolumn{9}{|c|}{ Activities and methods: participation } \\
\hline & \multicolumn{2}{|c|}{ Never } & \multicolumn{2}{|c|}{$\begin{array}{l}\text { Almost } \\
\text { never }\end{array}$} & \multicolumn{2}{|c|}{$\begin{array}{l}\text { Some of } \\
\text { the time }\end{array}$} & \multicolumn{2}{|c|}{$\begin{array}{l}\text { Most of the } \\
\text { time }\end{array}$} \\
\hline & $\mathrm{N}$ & $\%$ & $N$ & $\%$ & $\mathrm{~N}$ & $\%$ & $\mathrm{~N}$ & $\%$ \\
\hline $\begin{array}{l}\mathrm{HV} \text { asked caregiver to practice } \\
\text { activities with child }\end{array}$ & 0 & $0 \%$ & 0 & $0 \%$ & 3 & $50 \%$ & 3 & $50 \%$ \\
\hline $\begin{array}{l}\text { HV reviewed activities with caregiver } \\
\text { at end of visit and agreed on which } \\
\text { activities caregiver would practice } \\
\text { between visits }\end{array}$ & 1 & $16.7 \%$ & 1 & $16.7 \%$ & 2 & $33.3 \%$ & 2 & $33.3 \%$ \\
\hline \multicolumn{9}{|c|}{ Relationship between HV and caregiver } \\
\hline & \multicolumn{2}{|c|}{ Never } & \multicolumn{2}{|c|}{$\begin{array}{c}\text { Almost } \\
\text { never }\end{array}$} & \multicolumn{2}{|c|}{$\begin{array}{l}\text { Some of } \\
\text { the time }\end{array}$} & \multicolumn{2}{|c|}{$\begin{array}{l}\text { Most of the } \\
\text { time }\end{array}$} \\
\hline & $\mathrm{N}$ & $\%$ & $\mathrm{~N}$ & $\%$ & $\mathrm{~N}$ & $\%$ & $\mathrm{~N}$ & $\%$ \\
\hline HV listened to caregiver & 0 & $0 \%$ & 0 & $0 \%$ & 2 & $33.3 \%$ & 4 & $66.7 \%$ \\
\hline HV was responsive to caregiver & 0 & $0 \%$ & 0 & $0 \%$ & 3 & $50 \%$ & 3 & $50 \%$ \\
\hline $\begin{array}{l}\text { HV asked caregiver's opinion lasked } \\
\text { for questions throughout the visit }\end{array}$ & 2 & $33.3 \%$ & 2 & $33.3 \%$ & 1 & $16.7 \%$ & 1 & $16.7 \%$ \\
\hline $\begin{array}{l}\mathrm{HV} \text { encouraged and positively } \\
\text { reinforced the caregiver }\end{array}$ & 0 & $0 \%$ & 4 & $66.7 \%$ & 1 & $16.7 \%$ & 1 & $16.7 \%$ \\
\hline $\begin{array}{l}\text { Overall relationship between HV and } \\
\text { caregiver was warm and supportive }\end{array}$ & 0 & $0 \%$ & 0 & $0 \%$ & 1 & $16.7 \%$ & 5 & $83.3 \%$ \\
\hline \multicolumn{9}{|c|}{ Relationship between HV and child } \\
\hline & \multicolumn{2}{|c|}{ Never } & \multicolumn{2}{|c|}{$\begin{array}{l}\text { Almost } \\
\text { never }\end{array}$} & \multicolumn{2}{|c|}{$\begin{array}{l}\text { Some of } \\
\text { the time }\end{array}$} & \multicolumn{2}{|c|}{$\begin{array}{l}\text { Most of the } \\
\text { time }\end{array}$} \\
\hline & $\mathrm{N}$ & $\%$ & $\mathrm{~N}$ & $\%$ & $\mathrm{~N}$ & $\%$ & $\mathrm{~N}$ & $\%$ \\
\hline $\begin{array}{l}\text { HV listened to child and responded to } \\
\text { his/her vocalizations/gestures }\end{array}$ & 0 & $0 \%$ & 0 & $0 \%$ & 2 & $33.3 \%$ & 4 & $66.7 \%$ \\
\hline $\begin{array}{l}\text { HV praised child when he/she } \\
\text { attempted/completed an activity }\end{array}$ & 0 & $0 \%$ & 0 & $0 \%$ & 0 & $0 \%$ & 6 & $100 \%$ \\
\hline $\begin{array}{l}\text { HV talked about the activities the child } \\
\text { was doing throughout the visit, or } \\
\text { talked to child while child did the } \\
\text { activities }\end{array}$ & 0 & $0 \%$ & 1 & $33.3 \%$ & 1 & $16.7 \%$ & 3 & $50 \%$ \\
\hline $\begin{array}{l}\text { HV gave child enough time to explore } \\
\text { materials and complete activities }\end{array}$ & 0 & $0 \%$ & 0 & $0 \%$ & 3 & $50 \%$ & 3 & $50 \%$ \\
\hline $\begin{array}{l}\text { Overall relationship between HV and } \\
\text { child was warm and supportive }\end{array}$ & 0 & $0 \%$ & 0 & $0 \%$ & 0 & $0 \%$ & 6 & $100 \%$ \\
\hline
\end{tabular}




\begin{tabular}{|l|c|c|c|c|c|c|c|c|}
\hline \multicolumn{8}{|c|}{ Overall participation and atmosphere } \\
\hline & \multicolumn{2}{|c|}{ Never } & \multicolumn{2}{|c|}{$\begin{array}{c}\text { Almost } \\
\text { never }\end{array}$} & $\begin{array}{c}\text { Some of the } \\
\text { time }\end{array}$ & \multicolumn{2}{c|}{$\begin{array}{c}\text { Oost of the } \\
\text { time }\end{array}$} \\
\cline { 2 - 11 } & $\mathrm{N}$ & $\%$ & $\mathrm{~N}$ & $\%$ & $\mathrm{~N}$ & $\%$ & $\mathrm{~N}$ & $\%$ \\
\hline Child actively participated & 0 & $0 \%$ & 0 & $0 \%$ & 0 & $0 \%$ & 6 & $100 \%$ \\
\hline Caregiver actively participated & 0 & $0 \%$ & 0 & $0 \%$ & 5 & $83.3 \%$ & 1 & $16.7 \%$ \\
\hline $\begin{array}{l}\text { HV's made a significant effort to } \\
\text { encourage participation }\end{array}$ & 0 & $0 \%$ & 0 & $0 \%$ & 4 & $66.7 \%$ & 2 & $33.3 \%$ \\
\hline \multirow{2}{*}{$\begin{array}{l}\text { Overall atmosphere of the visit } \\
\text { Uncomfortable }\end{array}$} & \multicolumn{2}{|c|}{ Neutral } & $\begin{array}{c}\text { Happy/comf } \\
\text { ortable }\end{array}$ & \multicolumn{2}{|c|}{ Very happy } \\
\cline { 2 - 10 } & 0 & $0 \%$ & 0 & $0 \%$ & 5 & $83.3 \%$ & 1 & $16.7 \%$ \\
\hline
\end{tabular}

Table 6: Program description: Jamaica Home-Visit Program

\begin{tabular}{|l|l|}
\hline Name of the program & Jamaican Home Visiting Program \\
\hline Number of beneficiary children & n/a (see above). \\
\hline Vise range attended & $\begin{array}{l}6-18 \text { months (Clinic-Based Program 2011-2013), } \\
\text { although traditionally home-visit programs in Jamaica } \\
\text { include children aged 6 months to 3 or 4 years. }\end{array}$ \\
\hline Visit duration & Traditionally 1 visit/week or 1 visit/2 weeks \\
\hline \multirow{1}{*}{$\begin{array}{l}\text { HV profile (education, experience, } \\
\text { remuneration) }\end{array}$} & $\begin{array}{l}\text { Most have completed secondary or some secondary } \\
\text { education. Some have gone on to do additional 1-year } \\
\text { practical nursing program. In the most recent program } \\
\text { (clinic-based program) the home visitors were community } \\
\text { health aids. } \\
\text { All home visitors receive additional training in early } \\
\text { childhood development, early stimulation, home visiting } \\
\text { techniques, and relationship building. Training is } \\
\text { home visitors received 1-week upfront w/3-4 days } \\
\text { refresher half way through. } \\
\text { Home visitors are traditionally employed through the } \\
\text { University of West Indies (salaried, full time job). In the } \\
\text { clinic-based program, the health aids are regular clinic } \\
\text { employees (they do not receive any bonus for the visits, } \\
\text { but they are given money to cover bus fares). }\end{array}$ \\
\hline Number of families per home visitor & $\begin{array}{l}\text { Home visitors traditionally attend between 16-20 families. } \\
\text { In the clinic-based program there were 4-5 children per } \\
\text { home visitor. }\end{array}$ \\
\hline
\end{tabular}




\begin{tabular}{|c|c|}
\hline $\begin{array}{l}\text { Curriculum: how is visit content } \\
\text { determined? }\end{array}$ & $\begin{array}{l}\text { Activities for each visit are defined in the manual based } \\
\text { on child's age range, and home visitors are encouraged } \\
\text { to modify the activities according to the child's capabilities } \\
\text { (in practice, only more skilled home visitors are capable } \\
\text { of recognizing children's individual needs/development } \\
\text { status and modifying activities accordingly). }\end{array}$ \\
\hline $\begin{array}{l}\text { Curriculum: does the program } \\
\text { place a special emphasis on } \\
\text { language development? }\end{array}$ & $\begin{array}{l}\text { Language development is included within the program } \\
\text { curriculum. The methodology is constructed in such a } \\
\text { way that if home visitors implement the visit as designed } \\
\text { language development is consistently reinforced } \\
\text { throughout the visit. }\end{array}$ \\
\hline $\begin{array}{l}\text { Materials and manuals: What does } \\
\text { the home visitor bring with her to } \\
\text { the visit? }\end{array}$ & $\begin{array}{l}\text { Home visitors are supposed to bring materials (provided } \\
\text { by the program - toys, blocks, books, foam boards, etc.) } \\
\text { and a manual (not all need to carry manual). There is no } \\
\text { manual left with the family, although sometimes home } \\
\text { visitors leave toys with the family. }\end{array}$ \\
\hline $\begin{array}{l}\text { Supervision, monitoring and } \\
\text { support structure for home visitors }\end{array}$ & $\begin{array}{l}\text { Home visit programs in Jamaica generally employ two } \\
\text { levels of supervision: } \\
\text { - Contact with supervisor: via phone, e-mail, } \\
\text { whatever } \\
\text { - On-site monitoring of visits }\end{array}$ \\
\hline Visit preparation & $\begin{array}{l}\text { Home visitor should review and prepare all materials and } \\
\text { activities ("these are the things l'm going to do, these are } \\
\text { the things l'm going to take"). Normally, health aids meet } \\
\text { with supervisor to plan visits, and adjust according to } \\
\text { child's needs and developmental status. Health aids are } \\
\text { supposed to maintain books registering activities } \\
\text { reviewed (from previous visit), and completed per visit. }\end{array}$ \\
\hline Length of time in implementation & $\begin{array}{l}\text { Jamaica has implemented several programs over many } \\
\text { years since the mid-1970s, the most recent clinic-based } \\
\text { program ran from } 2011 \text { to } 2013 \text {. }\end{array}$ \\
\hline $\begin{array}{l}\text { Degree of rotation among home } \\
\text { visitors }\end{array}$ & $\begin{array}{l}\text { There was not a lot of turnover in the clinic-based } \\
\text { program. Most home visitors are quite stable, they love } \\
\text { and value their jobs and only leave if migrating or if they } \\
\text { go on to nursing school. Not all are hired as permanent } \\
\text { employees; some are contractual (none leave voluntarily, } \\
\text { some leave if their contract runs out). }\end{array}$ \\
\hline
\end{tabular}

\subsection{Brazil: Programa Primeira Infancia Melhor ${ }^{16}$}

The five visits observed took place in the town of Ronda Alta in north of the Rio Grande do Sul department (semi-urban context), with two different home visitors, one with 10 years' experience and one with one year of experience. The families visited were not particularly vulnerable. This is partly because program coordinators in Ronda Alta determined it was most

\footnotetext{
${ }^{16}$ Detailed information on the program can be found in http://www.pim.saude.rs.gov.br/v2/
} 
appropriate to visit families in relatively better conditions, due to the possibility that vulnerable families would reject the visit of the international researcher and/or feel uncomfortable with the visit. However, although PIM Ronda Alta operates in marginalized urban areas of the city, the team recognized that one of the main challenges they face has to do with reaching marginalized families in rural areas of the Ronda Alta municipality. It is worth mentioning that two of the families visited were incorporated into the program because the mother sought out the service, in other words, these two families were not selected based on financial need or vulnerability. Regardless, although the goal of PIM is to serve the most vulnerable families, the fact that families of varying socioeconomic classes seek out PIM's services shows that the program is widely recognized and valued within the community.

The two home visitors observed show a strong understanding of the needs and characteristics of families, and it is quite clear that they devote a significant amount of time to preparing for visits. In particular, their ability to respond and change the pace of the visit and/or to modify planned activities according to the needs and interests of children stands out.

For example, in one visit the child demonstrated great interest in a book that the home visitor had planned to introduce at the end of the visit. Instead of forcing the child to do the other activities planned, the home visitor recognized the child's interest and took advantage of this interest in order to incorporate new ways to use the book as an educational tool with the mother.

In the visits observed, the caregivers praised and encouraged their children often and practiced each activity with them without prompting from the home visitor. This is probably due to the fact that all families visited had at least several years of experience in the program and knew the visit methodology well. Nonetheless, at times the visits centered solely on the child. Home visitors could do more to promote the mother's (or caregiver's) participation. Still, the flow of the visit and overall relationship between home visitors and caregivers reflect the PIM home visitor's expertise.

Home visitors conclude the visits discussing with the caregiver what specific activities she will work on with her child during the week to come. Often these agreements center on the materials the caregiver will collect or the crafts she will make for the following weeks' activities, as opposed to interactive activities designed to promote child development and attachment. That said; it was evident that all the mothers visited dedicate much time to playing, reading, and talking with their children.

In three of the five visits observed, the mother or other family members discussed their perceptions of PIM (without any prompting). A grandmother mentioned that she notices a significant difference in the capabilities of her granddaughter who receives PIM visits versus her grandchildren of the same age who are not PIM beneficiaries. A mother commented that before she started receiving PIM visits she did not know how to play with her child and would often get frustrated when he cried or threw tantrums, but now she understands the importance of maternal affection and supervised exploration, now she feels much more competent as a mother. 
Finally, an especially innovative aspect of PIM Ronda Alta is the radio program "PIM Radio Hour" that the supervisor of the Ronda Alta home visitors leads every Friday. PIM Radio Hour provides information about PIM as well as general information about early child development, human development, maternal health and early education. This is an initiative unique to PIM Ronda Alta, it is not a universal PIM practice, but it certainly helps to ensure that PIM is recognized and valued by the community at large in Ronda Alta.

Table 7: Score distribution: PIM

\begin{tabular}{|c|c|c|c|c|c|c|c|c|}
\hline Description of activity & \multicolumn{8}{|c|}{ Overall score distribution } \\
\hline \multicolumn{9}{|c|}{ Review of activities done since last visit } \\
\hline & \multicolumn{2}{|c|}{$\begin{array}{c}\text { Not } \\
\text { observed }\end{array}$} & \multicolumn{2}{|c|}{ Inadequate } & \multicolumn{2}{|c|}{ Adequate } & \multicolumn{2}{|c|}{ Good } \\
\hline & $\mathrm{N}$ & $\%$ & $\mathrm{~N}$ & $\%$ & $\mathrm{~N}$ & $\%$ & $\mathrm{~N}$ & $\%$ \\
\hline $\begin{array}{l}\text { HV asked caregiver about play } \\
\text { sessions between visit }\end{array}$ & 0 & $0 \%$ & 0 & $0 \%$ & 1 & $20 \%$ & 4 & $80 \%$ \\
\hline $\begin{array}{l}\text { HV asked caregiver to } \\
\text { demonstrate w/child what had } \\
\text { been done since last visit }\end{array}$ & 2 & $40 \%$ & 0 & $0 \%$ & 1 & $20 \%$ & 2 & $40 \%$ \\
\hline \multicolumn{9}{|c|}{ Activities and methods: teaching } \\
\hline & \multicolumn{2}{|c|}{$\begin{array}{c}\text { Not } \\
\text { observed }\end{array}$} & \multicolumn{2}{|c|}{ Inadequate } & \multicolumn{2}{|c|}{ Adequate } & \multicolumn{2}{|c|}{ Good } \\
\hline & $\mathrm{N}$ & $\%$ & $\mathrm{~N}$ & $\%$ & $\mathrm{~N}$ & $\%$ & $\mathrm{~N}$ & $\%$ \\
\hline $\begin{array}{l}\text { HV used the program educational } \\
\text { material } \\
\text { (manual/booklet) }\end{array}$ & 0 & $0 \%$ & 0 & $0 \%$ & 3 & $60 \%$ & 2 & $40 \%$ \\
\hline $\begin{array}{l}\text { HV had prepared for the visit in } \\
\text { advance }\end{array}$ & 0 & $0 \%$ & 0 & $0 \%$ & 1 & $20 \%$ & 4 & $80 \%$ \\
\hline $\begin{array}{lrr}\text { HV } & \text { demonstrated } & \text { age- } \\
\text { appropriate } & \text { activities } & \text { and } \\
\text { materials } & & \end{array}$ & 0 & $0 \%$ & 0 & $0 \%$ & 0 & $0 \%$ & 5 & $100 \%$ \\
\hline $\begin{array}{l}\text { HV emphasized on language } \\
\text { development throughout the visit }\end{array}$ & 0 & $0 \%$ & 0 & $0 \%$ & 1 & $20 \%$ & 4 & $80 \%$ \\
\hline \multicolumn{9}{|c|}{ Activities and methods: explanation and demonstration } \\
\hline & \multicolumn{2}{|c|}{$\begin{array}{c}\text { Not } \\
\text { observed }\end{array}$} & \multicolumn{2}{|c|}{ Inadequate } & \multicolumn{2}{|c|}{ Adequate } & \multicolumn{2}{|c|}{ Good } \\
\hline & $\mathrm{N}$ & $\%$ & $\mathrm{~N}$ & $\%$ & $\mathrm{~N}$ & $\%$ & $\mathrm{~N}$ & $\%$ \\
\hline $\begin{array}{l}\text { HV's verbal explanation of } \\
\text { activities to the caregiver }\end{array}$ & 0 & $0 \%$ & 1 & $20 \%$ & 3 & $60 \%$ & 1 & $20 \%$ \\
\hline $\begin{array}{l}\text { HV's demonstration of activities } \\
\text { to the caregiver }\end{array}$ & 0 & $0 \%$ & 0 & $0 \%$ & 0 & $0 \%$ & 5 & $100 \%$ \\
\hline $\begin{array}{l}\text { HV's verbal explanation of } \\
\text { activities to the child }\end{array}$ & 0 & $0 \%$ & 0 & $0 \%$ & 2 & $40 \%$ & 3 & $60 \%$ \\
\hline $\begin{array}{l}\text { HV's demonstration of activities } \\
\text { to the child }\end{array}$ & 0 & $0 \%$ & 0 & $0 \%$ & 2 & $40 \%$ & 3 & $60 \%$ \\
\hline
\end{tabular}




\begin{tabular}{|c|c|c|c|c|c|c|c|c|}
\hline \multicolumn{9}{|c|}{ Activities and methods: participation } \\
\hline & \multicolumn{2}{|c|}{ Never } & \multicolumn{2}{|c|}{ Almost never } & \multicolumn{2}{|c|}{$\begin{array}{l}\text { Some of the } \\
\text { time }\end{array}$} & \multicolumn{2}{|c|}{$\begin{array}{l}\text { Most of the } \\
\text { time }\end{array}$} \\
\hline & $\mathrm{N}$ & $\%$ & $\mathrm{~N}$ & $\%$ & $\mathrm{~N}$ & $\%$ & $\mathrm{~N}$ & $\%$ \\
\hline $\begin{array}{l}\text { HV asked caregiver to practice } \\
\text { activities with child }\end{array}$ & 0 & $0 \%$ & 0 & $0 \%$ & 3 & $60 \%$ & 2 & $40 \%$ \\
\hline $\begin{array}{l}\text { HV reviewed activities with } \\
\text { caregiver at end of visit and } \\
\text { agreed on which activities } \\
\text { caregiver would practice between } \\
\text { visits }\end{array}$ & 0 & $0 \%$ & 1 & $20 \%$ & 3 & $60 \%$ & 1 & $20 \%$ \\
\hline \multicolumn{9}{|c|}{ Relationship between HV and caregiver } \\
\hline & \multicolumn{2}{|c|}{ Never } & \multicolumn{2}{|c|}{$\begin{array}{l}\text { Almost } \\
\text { never }\end{array}$} & \multicolumn{2}{|c|}{$\begin{array}{l}\text { Some of the } \\
\text { time }\end{array}$} & \multicolumn{2}{|c|}{$\begin{array}{l}\text { Most of the } \\
\text { time }\end{array}$} \\
\hline & $\mathrm{N}$ & $\%$ & $\mathrm{~N}$ & $\%$ & $\mathrm{~N}$ & $\%$ & $\mathrm{~N}$ & $\%$ \\
\hline HV listened to caregiver & 0 & $0 \%$ & 0 & $0 \%$ & 0 & $0 \%$ & 5 & $100 \%$ \\
\hline HV was responsive to caregiver & 0 & $0 \%$ & 0 & $0 \%$ & 0 & $0 \%$ & 5 & $100 \%$ \\
\hline $\begin{array}{l}\text { HV asked caregiver's opinion } \\
\text { lasked for questions throughout } \\
\text { the visit }\end{array}$ & 0 & $0 \%$ & 0 & $0 \%$ & 4 & $80 \%$ & 1 & $20 \%$ \\
\hline $\begin{array}{l}\mathrm{HV} \text { encouraged and positively } \\
\text { reinforced the caregiver }\end{array}$ & 0 & $0 \%$ & 0 & $0 \%$ & 2 & $40 \%$ & 3 & $60 \%$ \\
\hline $\begin{array}{l}\text { Overall relationship between HV } \\
\text { and caregiver was warm and } \\
\text { supportive }\end{array}$ & 0 & $0 \%$ & 0 & $0 \%$ & 0 & $0 \%$ & 5 & $100 \%$ \\
\hline \multicolumn{9}{|c|}{ Relationship between HV and child } \\
\hline & \multicolumn{2}{|c|}{ Never } & \multicolumn{2}{|c|}{$\begin{array}{l}\text { Almost } \\
\text { never }\end{array}$} & \multicolumn{2}{|c|}{$\begin{array}{l}\text { Some of the } \\
\text { time }\end{array}$} & \multicolumn{2}{|c|}{$\begin{array}{l}\text { Most of the } \\
\text { time }\end{array}$} \\
\hline & $\mathrm{N}$ & $\%$ & $\mathrm{~N}$ & $\%$ & $\mathrm{~N}$ & $\%$ & $\mathrm{~N}$ & $\%$ \\
\hline $\begin{array}{l}\mathrm{HV} \text { listened to child and } \\
\text { responded to his/her } \\
\text { vocalizations/gestures }\end{array}$ & 0 & $0 \%$ & 0 & $0 \%$ & 0 & $0 \%$ & 5 & $100 \%$ \\
\hline $\begin{array}{l}\text { HV praised child when he/she } \\
\text { attempted/completed an activity }\end{array}$ & 0 & $0 \%$ & 0 & $0 \%$ & 3 & $60 \%$ & 2 & $40 \%$ \\
\hline $\begin{array}{l}\text { HV talked about the activities the } \\
\text { child was doing throughout the } \\
\text { visit, or talked to child while child } \\
\text { did the activities }\end{array}$ & 0 & $0 \%$ & 0 & $0 \%$ & 0 & $0 \%$ & 5 & $100 \%$ \\
\hline $\begin{array}{l}\text { HV gave child enough time to } \\
\text { explore materials and complete } \\
\text { activities }\end{array}$ & 0 & $0 \%$ & 0 & $0 \%$ & 0 & $0 \%$ & 5 & $100 \%$ \\
\hline $\begin{array}{l}\text { Overall relationship between HV } \\
\text { and child was warm and } \\
\text { supportive }\end{array}$ & 0 & $0 \%$ & 0 & $0 \%$ & 0 & $0 \%$ & 5 & $100 \%$ \\
\hline \multicolumn{9}{|c|}{ Overall participation and atmosphere } \\
\hline & \multicolumn{2}{|c|}{ Never } & \multicolumn{2}{|c|}{$\begin{array}{l}\text { Almost } \\
\text { never }\end{array}$} & \multicolumn{2}{|c|}{$\begin{array}{c}\text { Some of the } \\
\text { time }\end{array}$} & \multicolumn{2}{|c|}{$\begin{array}{l}\text { Most of the } \\
\text { time }\end{array}$} \\
\hline & $\mathrm{N}$ & $\%$ & $\mathrm{~N}$ & $\%$ & $\mathrm{~N}$ & $\%$ & $\mathrm{~N}$ & $\%$ \\
\hline
\end{tabular}




\begin{tabular}{|l|c|c|c|c|c|c|c|c|}
\hline Child actively participated & 0 & $0 \%$ & 0 & $0 \%$ & 0 & $0 \%$ & 5 & $100 \%$ \\
\hline Caregiver actively participated & 0 & $0 \%$ & 0 & $0 \%$ & 2 & $40 \%$ & 3 & $60 \%$ \\
\hline $\begin{array}{l}\text { HV's made a significant effort to } \\
\text { encourage participation }\end{array}$ & 0 & $0 \%$ & 0 & $0 \%$ & 1 & $20 \%$ & 4 & $80 \%$ \\
\hline \multirow{2}{*}{ Overall atmosphere of the visit } & \multicolumn{2}{|c|}{ Uncomfortable } & \multicolumn{2}{|c|}{ Neutral } & $\begin{array}{c}\text { Happy / } \\
\text { comfortable }\end{array}$ & \multicolumn{2}{|c|}{ Very happy } \\
\cline { 2 - 10 } & 0 & $0 \%$ & 0 & $0 \%$ & 1 & $20 \%$ & 4 & $80 \%$ \\
\hline
\end{tabular}

Table 8: Program description: PIM

\begin{tabular}{|c|c|}
\hline Name of the program & Programa Primeira Infancia Melhor \\
\hline Number of beneficiary children & $\begin{array}{l}268 \text { municipalities } \\
2,733 \text { home visitors } \\
54,460 \text { families } \\
59,906 \text { children served } \\
8,169 \text { expecting mothers served } \\
\text { It is a regional program, led by the state government of } \\
\text { Rio Grande do Sul (does not have national coverage). }\end{array}$ \\
\hline Age range attended & Children aged 0 to 6 years old (and pregnant women) \\
\hline Visit frequency & $\begin{array}{c}\text { Children } 0 \text { to } 3 \text { : weekly } \\
\text { Children } 4 \text { to } 6 \text { : weekly in groups of } 4 \text { to } 6\end{array}$ \\
\hline Visit duration & $\sim 45$ minutes \\
\hline $\begin{array}{l}\text { Home visitor profile (education, } \\
\text { experience, remuneration) }\end{array}$ & $\begin{array}{l}\text { Most home visitors have at least a high school diploma, } \\
\text { but it is not a requirement. They receive } 60 \text { hours of } \\
\text { training (more if they don't have a high school degree). } \\
\text { Home visitors receive a salary, although the amount } \\
\text { varies among municipalities. State funds cover the } \\
\text { minimum wage, and municipal governments can } \\
\text { complement the salary with additional municipal funds. }\end{array}$ \\
\hline $\begin{array}{l}\text { Number of families per home } \\
\text { visitor }\end{array}$ & $\begin{array}{l}20 \text { families per home visitor if } 40 \text { hs per week contract, } 17 \\
\text { families if } 30 \text { hs per week and } 14 \text { families if } 20 \text { hs per week } \\
\text { contract. }\end{array}$ \\
\hline $\begin{array}{l}\text { Curriculum: how is visit content } \\
\text { determined? }\end{array}$ & $\begin{array}{l}\text { Every home visitor and every family have a Family Guide, } \\
\text { with information about ECD, early stimulation activities, } \\
\text { and good practices for child development. The activities } \\
\text { for each visit are not defined in the manual, home visitors } \\
\text { are responsible for preparing their own activities } \\
\text { according to the individual needs/abilities of each child, } \\
\text { with the orientation of the municipal monitor (supervisor). }\end{array}$ \\
\hline $\begin{array}{l}\text { Curriculum: is there a special } \\
\text { emphasis in language } \\
\text { development? }\end{array}$ & $\begin{array}{l}\text { There is no special emphasis on language above other } \\
\text { development dimensions, but home visitors are trained to } \\
\text { put special emphasis in language if they notice that the } \\
\text { child needs special attention in this area. }\end{array}$ \\
\hline $\begin{array}{l}\text { Materials and manuals: What does } \\
\text { the home visitor bring with her to } \\
\text { the visit? }\end{array}$ & $\begin{array}{l}\text { Home visitors bring their PIM backpack with the Family } \\
\text { Guide (which they review together with the mother during } \\
\text { the visit), and also toys and books - most of which are }\end{array}$ \\
\hline
\end{tabular}




\begin{tabular}{|c|c|}
\hline & $\begin{array}{l}\text { constructed by the home visitor (using municipal } \\
\text { resources). }\end{array}$ \\
\hline $\begin{array}{l}\text { Supervision, monitoring and } \\
\text { support structure for home visitors }\end{array}$ & $\begin{array}{l}\text { Each municipality has a municipal technical team (GTM) } \\
\text { responsible for identifying families to attend, supervising } \\
\text { the home visitors' performance, evaluating the program } \\
\text { and lessons learned, and articulating PIM with the } \\
\text { network of local services. GTM (Grupo Tecnico } \\
\text { Municipa) is composed of health, social services and } \\
\text { education sector professionals as well as other public } \\
\text { employees. } \\
\text { The main supervision comes from the municipal and } \\
\text { GTM's monitors who meet with the home visitors once a } \\
\text { week to help them the plan their visits and discuss the } \\
\text { advances/issues present in each family. Monitors and } \\
\text { GTM provide ongoing direct supervision, training and } \\
\text { support. Monitors receive a salary (working full time or } \\
\text { part-time) and most have a professional degree in ECD } \\
\text { or other relevant areas. }\end{array}$ \\
\hline Visit preparation & $\begin{array}{l}\text { For each visit the home visitor should bring the materials } \\
\text { she has selected for each activity and should also be } \\
\text { prepared to review the Family Guide with the caregiver } \\
\text { and give specific orientation/information. }\end{array}$ \\
\hline Length of time in implementation & 10 years \\
\hline $\begin{array}{l}\text { Degree of rotation among home } \\
\text { visitors }\end{array}$ & $\begin{array}{l}\text { Rotation varies. Some home visitors are students, in } \\
\text { which case they work one to two years while studying and } \\
\text { then look for other (better paid) jobs. Other times home } \\
\text { visitors are selected for political motives (vote-buying), in } \\
\text { which case there is usually higher rotation. }\end{array}$ \\
\hline
\end{tabular}

\subsection{Peru: Cuna Más ${ }^{17}$}

In Peru's Programa Cuna Más, 7 visits were observed, with 6 different home visitors, including one male home visitor. Each home visitor had around one year of experience (the program is about one year old). Three visits took place in indigenous Awajún communities of the Amazon in the northeastern part of the country, and four visits took place in a Quechua community of the Altiplano (high desert) in the southern part of the country. Cuna Más program directors arranged this itinerary to highlight the diversity of the Program's beneficiaries (Cuna Más is a nation-wide program). In both regions the visits were conducted primarily in indigenous languages (Awajún in the Amazons and Quechua in the Altiplano) ${ }^{18}$.

\footnotetext{
17 Detailed information on the program can be found in http://www.cunamas.gob.pe/

18 In the Amazon regions where the entire visit was conducted in Awajún, the quality of the explanation given to caregiver and child was not evaluated due to these language challenges. In the altiplano the visits were conducted in a mix of Quechua and Spanish, and there was more time after the visits to discuss with the program coordinator and home visitor how she had presented and explained the activities, so all items were scored.
} 
There are several aspects that distinguish Cuna Más from other programs. First, each family creates Espacios de Juego (Play Spaces), with the help of the home visitor, as a prerequisite for joining the program. In each home visited, the Espacio de Juego occupy a significant space in the household. Families post pictures, gather toys, drawings, mobiles, books, and a large cushion for the child to play on. Each space includes a mix of homemade objects and purchased toys/posters. Most spaces are culturally relevant, as well. In the Amazons for example, Espacios de Juego includewoodcarvings of animals native to the Amazon (turtles, fish, etc.), and in the Altiplano families hang quilted scenes and mobiles in the art style native to their culture. In the Amazons some families even made additional play structures next to the homes. Families are very proud of these structures, and, moreover, the construction of the Espacios de Juego, particularly in the Amazon where fathers constructed wooden play houses and wooden figurines, are an effective way to encourage fathers to become involved in their child's development.

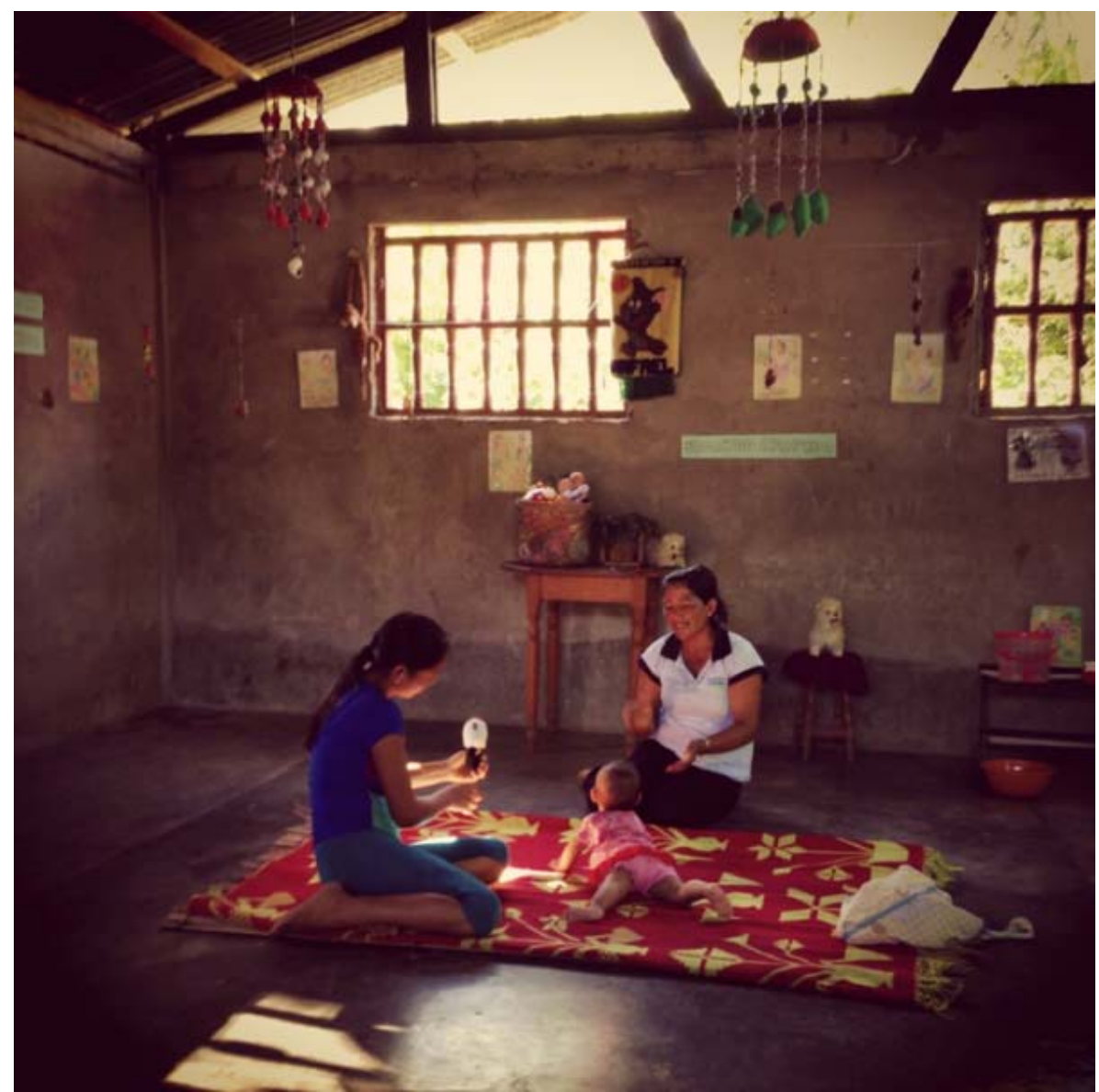

Mother and child in the Nazareth community of the Amazons with home visitor (in white shirt).

As well as toys, posters, and books, each Espacio de Juego includes a homemade lavamanos (sink), made out of a water bottle and a bucket. Before each visit the home visitor instructs the mother to help the child wash his or her hands (the mother and home visitor also washed their hands). 
Another unique aspect of Cuna Más is the Kits de Juego. Each family receives a Kit de Juego, with blocks, animal figures, storybooks, and other simple play materials. In addition, home visitors bring a backpack with toys and books to each visit and then leave the toys and books with the family. The following week, the home visitor collects the toys she had left in the previous visit and replaces them with new toys. This ensures families can easily practice the activities developed in each visit. Children know the routine well, in all of the visits observed the children did not protest when the home visitor took back the toys from the previous week; they knew that the toys are always replaced. Importantly, home visitors also encourage families to use objects from the home and surrounding environment as toys and educational material for their children, so that the rotating toy sets are not the only play materials that the children have in the household. The practice of rotating toy sets is not without its problems, however. After one year of implementation many toys have been lost or damaged, and Cuna Más directors are discussing ways to modify this methodology.

Cuna Más visits are more structured and standardized than those of other programs (with the exception of $\mathrm{CNH}$ in Ecuador and Jamaica). The visit is divided into three moments: (1) Vida en familia (Family life), (2) Jugando aprendo (Learning by playing), and (3) Cuentame un cuento (Tell me a story). The majority of the home visitors observed are very competent, they clearly have a solid grounding in child development and are able to adapt the visit to best promote each child's individual needs and interests. The visits in the Quechua community were particularly strong in terms of the quality of the participation of the caregiver. Beyond simply inviting the caregiver to practice the activities with the children and asking her if she "had any questions," the home visitors observed in the Quechua community give the caregiver the opportunity to select which activities she wanted to do (from a menu of several options), and always explain the activity to the caregiver first and asked her how she would like to introduce the activity to the child. This provokes a dialogue between the home visitor and caregiver, and the home visitors use this opportunity to discuss how to promote the child's autonomy (independence) and the importance of always talking to the child.

Like PIM, Cuna Más is highly valued in the communities visited. Mothers, fathers, pre-school teachers, and other community members discussed the differences they observe between Cuna Más children and other children who are not program beneficiaries. Cuna Más children are more active, more social, and learn faster, according to this anecdotal evidence.

Table 9: Score distribution: Cuna Más

\begin{tabular}{|c|c|c|c|c|c|c|c|c|}
\hline Description of activity & \multicolumn{6}{|c|}{ Overall score distribution $^{19}$} \\
\hline \multicolumn{1}{|c|}{ Review of activities done since last visit } \\
\hline & $\begin{array}{c}\text { Not } \\
\text { observed }\end{array}$ & Inadequate & Adequate & \multicolumn{2}{c|}{ Good } \\
\cline { 2 - 9 } & $\mathrm{N}$ & $\%$ & $\mathrm{~N}$ & $\%$ & $\mathrm{~N}$ & $\%$ & $\mathrm{~N}$ & $\%$ \\
\hline
\end{tabular}

${ }^{19}$ Table does not include “non-applicable,” thus not all rows add up to $100 \%$, and total N varies according by item 


\begin{tabular}{|c|c|c|c|c|c|c|c|c|}
\hline $\begin{array}{l}\text { HV asked caregiver about play } \\
\text { sessions between visit }\end{array}$ & 0 & $0 \%$ & 1 & $14.3 \%$ & 2 & $14.3 \%$ & 5 & $71.4 \%$ \\
\hline $\begin{array}{l}\text { HV asked caregiver to } \\
\text { demonstrate w/child what had } \\
\text { been done since last visit }\end{array}$ & 0 & $0 \%$ & 1 & $14.3 \%$ & 3 & $42.9 \%$ & 3 & $42.9 \%$ \\
\hline \multicolumn{9}{|c|}{ Activities and methods: teaching } \\
\hline & \multicolumn{2}{|c|}{$\begin{array}{c}\text { Not } \\
\text { observed }\end{array}$} & \multicolumn{2}{|c|}{ Inadequate } & \multicolumn{2}{|c|}{ Adequate } & \multicolumn{2}{|c|}{ Good } \\
\hline & $\mathrm{N}$ & $\%$ & $\mathrm{~N}$ & $\%$ & $\mathrm{~N}$ & $\%$ & $\mathrm{~N}$ & $\%$ \\
\hline $\begin{array}{l}\text { HV had prepared for the visit in } \\
\text { advance }\end{array}$ & 0 & $0 \%$ & 1 & $14.3 \%$ & 0 & $0 \%$ & 6 & $85.7 \%$ \\
\hline 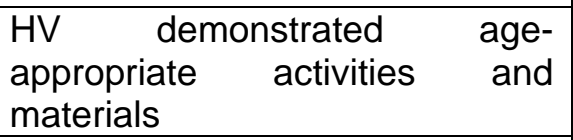 & 0 & $0 \%$ & 0 & $0 \%$ & 1 & $14.3 \%$ & 6 & $85.7 \%$ \\
\hline $\begin{array}{l}\text { HV emphasized on language } \\
\text { development throughout the visit }\end{array}$ & 0 & $0 \%$ & 0 & $0 \%$ & 3 & $42.9 \%$ & 3 & $42.9 \%$ \\
\hline \multicolumn{9}{|c|}{ Activities and methods: explanation and demonstration } \\
\hline & \multicolumn{2}{|c|}{$\begin{array}{c}\text { Not } \\
\text { observed }\end{array}$} & \multicolumn{2}{|c|}{ Inadequate } & \multicolumn{2}{|c|}{ Adequate } & \multicolumn{2}{|c|}{ Good } \\
\hline & $\mathrm{N}$ & $\%$ & $N$ & $\%$ & $\mathrm{~N}$ & $\%$ & $\mathrm{~N}$ & $\%$ \\
\hline $\begin{array}{l}\text { HV's verbal explanation of } \\
\text { activities to the caregiver }\end{array}$ & 1 & $20 \%$ & 1 & $20 \%$ & 0 & $0 \%$ & 3 & $60 \%$ \\
\hline $\begin{array}{l}\text { HV's demonstration of activities } \\
\text { to the caregiver }\end{array}$ & 0 & $0 \%$ & 1 & $14.3 \%$ & 3 & $42.9 \%$ & 3 & $42.9 \%$ \\
\hline $\begin{array}{l}\text { HV's verbal explanation of } \\
\text { activities to the child }\end{array}$ & 0 & $0 \%$ & 1 & $14.3 \%$ & 2 & $28.6 \%$ & 4 & $57.1 \%$ \\
\hline $\begin{array}{l}\text { HV's demonstration of activities } \\
\text { to the child }\end{array}$ & 0 & $0 \%$ & 2 & $28.6 \%$ & 5 & $71.4 \%$ & 0 & $0 \%$ \\
\hline \multicolumn{9}{|c|}{ Activities and methods: participation } \\
\hline & \multicolumn{2}{|c|}{ Never } & \multicolumn{2}{|c|}{ Almost never } & \multicolumn{2}{|c|}{$\begin{array}{l}\text { Some of the } \\
\text { time }\end{array}$} & \multicolumn{2}{|c|}{$\begin{array}{l}\text { Most of the } \\
\text { time }\end{array}$} \\
\hline & $\mathrm{N}$ & $\%$ & $\mathrm{~N}$ & $\%$ & $\mathrm{~N}$ & $\%$ & $\mathrm{~N}$ & $\%$ \\
\hline $\begin{array}{l}\text { HV asked caregiver to practice } \\
\text { activities with child }\end{array}$ & 0 & $0 \%$ & 0 & $0 \%$ & 0 & $0 \%$ & 7 & $100 \%$ \\
\hline $\begin{array}{l}\text { HV reviewed activities with } \\
\text { caregiver at end of visit and } \\
\text { agreed on which activities } \\
\text { caregiver would practice between } \\
\text { visits }\end{array}$ & 0 & $0 \%$ & 0 & $0 \%$ & 1 & $14.3 \%$ & 6 & $85.7 \%$ \\
\hline \multicolumn{9}{|c|}{ Relationship between HV and caregiver } \\
\hline & \multicolumn{2}{|c|}{ Never } & \multicolumn{2}{|c|}{$\begin{array}{c}\text { Almost } \\
\text { never }\end{array}$} & \multicolumn{2}{|c|}{$\begin{array}{l}\text { Some of the } \\
\text { time }\end{array}$} & \multicolumn{2}{|c|}{$\begin{array}{c}\text { Most of the } \\
\text { time }\end{array}$} \\
\hline & $\mathrm{N}$ & $\%$ & $\mathrm{~N}$ & $\%$ & $\mathrm{~N}$ & $\%$ & $\mathrm{~N}$ & $\%$ \\
\hline HV listened to caregiver & 0 & $0 \%$ & 0 & $0 \%$ & 0 & $0 \%$ & 7 & $100 \%$ \\
\hline
\end{tabular}




\begin{tabular}{|c|c|c|c|c|c|c|c|c|}
\hline HV was responsive to caregiver & 0 & $0 \%$ & 1 & $14.3 \%$ & 1 & $1.14 \%$ & 5 & $71.4 \%$ \\
\hline $\begin{array}{l}\text { HV asked caregiver's opinion } \\
\text { lasked for questions throughout } \\
\text { the visit }\end{array}$ & 0 & $0 \%$ & 1 & $14.3 \%$ & 4 & $57.1 \%$ & 2 & $28.6 \%$ \\
\hline $\begin{array}{l}\mathrm{HV} \text { encouraged and positively } \\
\text { reinforced the caregiver }\end{array}$ & 0 & $0 \%$ & 1 & $14.3 \%$ & 2 & $28.6 \%$ & 4 & $57.1 \%$ \\
\hline $\begin{array}{l}\text { Overall relationship between HV } \\
\text { and caregiver was warm and } \\
\text { supportive }\end{array}$ & 0 & $0 \%$ & 1 & $14.3 \%$ & 0 & $0 \%$ & 6 & $85.7 \%$ \\
\hline \multicolumn{9}{|c|}{ Relationship between HV and child } \\
\hline & \multicolumn{2}{|c|}{ Never } & \multicolumn{2}{|c|}{$\begin{array}{c}\text { Almost } \\
\text { never }\end{array}$} & \multicolumn{2}{|c|}{$\begin{array}{c}\text { Some of the } \\
\text { time }\end{array}$} & \multicolumn{2}{|c|}{$\begin{array}{l}\text { Most of the } \\
\text { time }\end{array}$} \\
\hline & $\mathrm{N}$ & $\%$ & $\mathrm{~N}$ & $\%$ & $\mathrm{~N}$ & $\%$ & $\mathrm{~N}$ & $\%$ \\
\hline $\begin{array}{l}\mathrm{HV} \text { listened to child and } \\
\text { responded to his/her } \\
\text { vocalizations/gestures }\end{array}$ & 0 & $0 \%$ & 0 & $0 \%$ & 1 & $14.3 \%$ & 6 & $85.7 \%$ \\
\hline $\begin{array}{l}\text { HV praised child when he/she } \\
\text { attempted/completed an activity }\end{array}$ & 0 & $0 \%$ & 1 & $14.3 \%$ & 1 & $14.3 \%$ & 5 & $71.4 \%$ \\
\hline $\begin{array}{l}\text { HV talked about the activities the } \\
\text { child was doing throughout the } \\
\text { visit, or talked to child while child } \\
\text { did the activities }\end{array}$ & 0 & $0 \%$ & 2 & $28.6 \%$ & 2 & $28.7 \%$ & 3 & $42.9 \%$ \\
\hline $\begin{array}{l}\text { HV gave child enough time to } \\
\text { explore materials and complete } \\
\text { activities }\end{array}$ & 0 & $0 \%$ & 1 & $14.3 \%$ & 0 & $0 \%$ & 6 & $85.7 \%$ \\
\hline $\begin{array}{l}\text { Overall relationship between HV } \\
\text { and child was warm and } \\
\text { supportive }\end{array}$ & 0 & $0 \%$ & 1 & $14.3 \%$ & 0 & $0 \%$ & 6 & $85.7 \%$ \\
\hline \multicolumn{9}{|c|}{ Overall participation and atmosphere } \\
\hline & \multicolumn{2}{|c|}{ Never } & \multicolumn{2}{|c|}{$\begin{array}{l}\text { Almost } \\
\text { never }\end{array}$} & \multicolumn{2}{|c|}{$\begin{array}{c}\text { Some of the } \\
\text { time }\end{array}$} & \multicolumn{2}{|c|}{$\begin{array}{l}\text { Most of the } \\
\text { time }\end{array}$} \\
\hline & $\mathrm{N}$ & $\%$ & $\mathrm{~N}$ & $\%$ & $\mathrm{~N}$ & $\%$ & $\mathrm{~N}$ & $\%$ \\
\hline Child actively participated & 0 & $0 \%$ & 1 & $14.3 \%$ & 0 & $0 \%$ & 6 & $85.7 \%$ \\
\hline Caregiver actively participated & 0 & $0 \%$ & 1 & $14.3 \%$ & 2 & $28.6 \%$ & 4 & $57.1 \%$ \\
\hline $\begin{array}{l}\text { HV's made a significant effort to } \\
\text { encourage participation }\end{array}$ & 1 & $14.3 \%$ & 0 & $0 \%$ & 1 & $14.3 \%$ & 5 & $71.4 \%$ \\
\hline \multirow{2}{*}{ Overall atmosphere of the visit } & \multicolumn{2}{|c|}{ Uncomfortable } & \multicolumn{2}{|c|}{ Neutral } & \multicolumn{2}{|c|}{$\begin{array}{c}\text { Happy I } \\
\text { comfortable }\end{array}$} & \multicolumn{2}{|c|}{ Very happy } \\
\hline & 1 & $14.3 \%$ & 0 & $0 \%$ & 5 & $71.4 \%$ & 1 & $14.3 \%$ \\
\hline
\end{tabular}


Table 10: Program description: Cuna Más

\begin{tabular}{|c|c|}
\hline Name of the program & Cuna Más \\
\hline Number of beneficiary children & $\begin{array}{l}\sim 45,000 \text { children at the time of visit } \\
\text { It's a national program, directed at vulnerable rural areas } \\
\text { of the country }\end{array}$ \\
\hline Age range attended & $\begin{array}{l}\text { Children aged } 0 \text { to } 3 \text { years. Pregnant mothers are also } \\
\text { visited monthly }\end{array}$ \\
\hline Visit frequency & Weekly \\
\hline Visit duration & 1 hour \\
\hline $\begin{array}{l}\text { HV profile (education, experience, } \\
\text { remuneration) }\end{array}$ & $\begin{array}{l}\text { Home visitors have to be able to read and write. Most } \\
\text { have a high school degree; some have also completed } \\
\text { some higher education. They receive a monthly stipend } \\
\text { equivalent to } 150 \text { USD (a significant amount, more than } \\
\text { symbolic). } \\
\text { The initial training is one week long, with continuous } \\
\text { "refresher" trainings throughout the year. }\end{array}$ \\
\hline $\begin{array}{l}\text { Number of families per home } \\
\text { visitor }\end{array}$ & $\begin{array}{l}\text { In average each home visitor is responsible for visiting } 10 \\
\text { families. In semi-urban areas some home visitors have } 12 \\
\text { families, and in rural areas with large distances between } \\
\text { homes home visitors attend less than } 10 \text { families. }\end{array}$ \\
\hline $\begin{array}{l}\text { Curriculum: how is visit content } \\
\text { determined? }\end{array}$ & $\begin{array}{l}\text { Each home visitor has a Curriculum Guide to help guide } \\
\text { visit planning based on child's age range, but activities for } \\
\text { each visit are not rigidly defined. The first } 8 \text { weeks ( } 2 \\
\text { months) of visits are the introduction period, in which the } \\
\text { home visitor presents the program, develops trust with the } \\
\text { family, helps create the Espacio de Juego, and identifies } \\
\text { child's strengths and weaknesses through free play. After } \\
\text { this period the regular visits begin. } \\
\text { Cuna Más places less of emphasis than other programs } \\
\text { on the home visitor doing the activity with the child. This } \\
\text { happens in practice, but home visitors are instructed to } \\
\text { help the caregiver develop the activity first with the child. }\end{array}$ \\
\hline $\begin{array}{l}\text { Curriculum: is there a special } \\
\text { emphasis } \text { in } \text { language } \\
\text { development? }\end{array}$ & $\begin{array}{l}\text { The focus is on holistic child development, but home } \\
\text { visitors are trained to emphasize language development } \\
\text { in all moments of the visit (talking about what the child is } \\
\text { doing, talking to the child even if the activity is designed } \\
\text { for motor development, etc.). }\end{array}$ \\
\hline $\begin{array}{l}\text { Materials and manuals: What does } \\
\text { the home visitor bring with her to } \\
\text { the visit? }\end{array}$ & $\begin{array}{l}\text { The home visitor brings her backpack with materials and } \\
\text { rotating toy set to leave with the family. There are no } \\
\text { program manuals or literature for the family. }\end{array}$ \\
\hline
\end{tabular}




\begin{tabular}{|l|l|}
\hline Supervision, monitoring and & $\begin{array}{l}\text { There is one Technical Assistant per every two } \\
\text { communities, who in charge of directly supervising } \\
\text { home visitors. The frequency and quality of supervision } \\
\text { varies greatly by community, and program directors were } \\
\text { at the time this survey was conducted evaluating how to } \\
\text { increase/strengthen the supervision mechanisms. } \\
\text { support structure for home visitors } \\
\text { Each community also forms a Management Committee } \\
\text { and a Supervision Committee, responsible for managing } \\
\text { the financial resources funnelled to Cuna Más from the } \\
\text { national government and articulating the program with } \\
\text { regional and community authorities and other social } \\
\text { programs. There is also a Community Technical Assistant } \\
\text { who is responsible for presenting the program to } \\
\text { community leaders and maintaining consistent } \\
\text { community articulation. }\end{array}$ \\
\hline Visit preparation & $\begin{array}{l}\text { The home visitor should have each of the visits three } \\
\text { moments planned (Vida en Familia, Jugando Aprendo, } \\
\text { Cuéntame un Cuento) and all materials necessary for the } \\
\text { activities. }\end{array}$ \\
\hline Time in implementation & $\begin{array}{l}\text { About 1 year (program was launched at scale in April, } \\
\text { 2013) at the time the survey was conducted }\end{array}$ \\
\hline $\begin{array}{l}\text { There is a higher level of rotation among home visitors in } \\
\text { coffee producing areas where home visitors can earn } \\
\text { more working in the coffee harvest. There are also home } \\
\text { visitors who work while studying (university), and then } \\
\text { leave to find higher paying jobs upon completion of their } \\
\text { degree. }\end{array}$ \\
\hline Degree of rotation among hom \\
\hline visitors
\end{tabular}




\subsection{Nicaragua: Programa de Acompañamiento a la Política de Primera Infancia ${ }^{20}$}

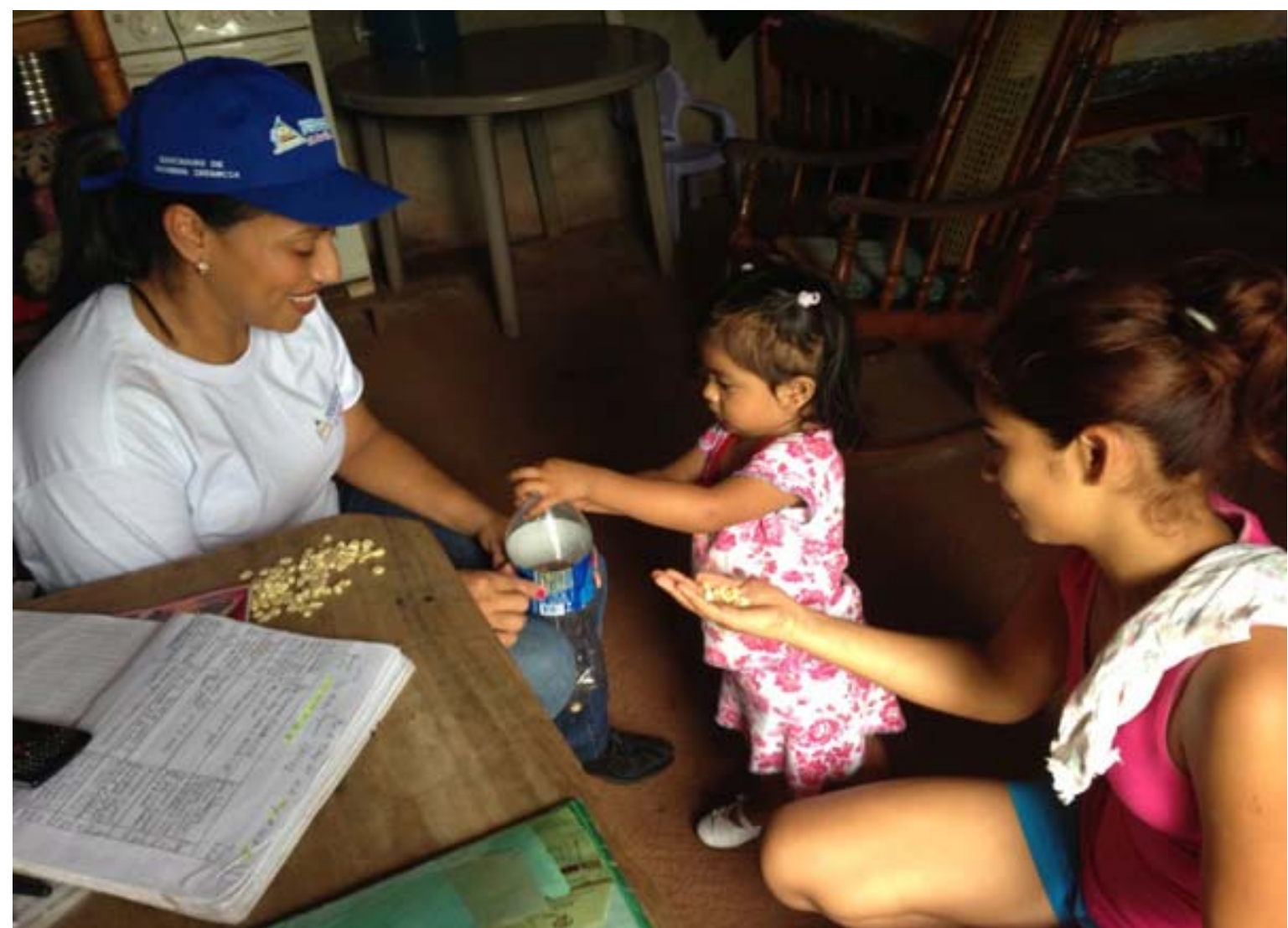

Home visitor (in blue hat) demonstrates how to use objects from the household to promote fine motor development.

Nicaragua's Programa de Acompañamiento a la Política de Primera Infancia (PAIPPI) is the newest program evaluated in this study (of the Child development programs); it had only been in implementation for about six months when fieldwork was conducted. Fieldwork took place in three different communities: Boaco (urban), Camoapa (semi-urban), and La Libertad (rural).

Visit quality varies greatly among the three communities visited. In the first community visited, the two visits observed (with two different home visitors) did not follow the established methodology. The home visitors did not develop any activities with the child; rather, they read the program booklet (cartilla) word for word and asked the caregiver if she had been taking her child to his or her medical check-ups (vaccination). Home visitors barely seek the participation of caregiver or child.

\footnotetext{
${ }^{20}$ Detailed information on the program can be found in http://www.mifamilia.gob.ni/?page id=245
} 
In Camoapa and La Libertad, on the other hand, the visits were much more organized and home visitors are much better prepared. This difference can most likely be explained by the fact that Camoapa and La Libertad were incorporated in PAIPPI's predecessor program, Programa de Atención Integral a la Primera Infancia (PAININ). Thus, municipal technical supervisors and the home visitors themselves in these communities had previous experience in home visits, whereas the methodology is completely new for most of the supervisors and home visitors in Boaco.

PAIPPI's strength lies in the use of recursos de medio (homemade toys and learning materials, from objects found in the household or surrounding areas). This is particularly important in given that the PAIPPI's beneficiary families are considerably more vulnerable than families visited in other programs (many beneficiary families in Nicaragua have dirt floors and one toy at most). PAIPPI does not provide toys or any kind of learning material for home visitors or families; thus, home visitors are expected to develop their own toys and materials, and, moreover, to help families find objects in the household to use (although some municipal delegations provide home visitors with basic materials like cloth, paper, and glue to make toys) ${ }^{21}$. In one visit observed in Camoapa, for example, a home visitor used an empty water bottle and corn kernels to help the child practice fine motor skills (putting the corn kernels into the small opening of the bottle). Mother and child were both very happy with this activity.

Table 11: Score distribution: PAIPPI

\begin{tabular}{|c|c|c|c|c|c|c|c|c|}
\hline Description of activity & \multicolumn{8}{|c|}{ Overall score distribution } \\
\hline \multicolumn{9}{|c|}{ Review of activities done since last visit } \\
\hline & \multicolumn{2}{|c|}{$\begin{array}{c}\text { Not } \\
\text { observed }\end{array}$} & \multicolumn{2}{|c|}{ Inadequate } & \multicolumn{2}{|c|}{ Adequate } & \multicolumn{2}{|c|}{ Good } \\
\hline & $\mathrm{N}$ & $\%$ & $\mathrm{~N}$ & $\%$ & $\mathrm{~N}$ & $\%$ & $\mathrm{~N}$ & $\%$ \\
\hline $\begin{array}{l}\text { HV asked caregiver about play } \\
\text { sessions between visit }\end{array}$ & 4 & $66.7 \%$ & 0 & $0 \%$ & 2 & $33.3 \%$ & 0 & $0 \%$ \\
\hline $\begin{array}{l}\text { HV asked caregiver to } \\
\text { demonstrate w/child what had } \\
\text { been done since last visit }\end{array}$ & 6 & $100 \%$ & 0 & $0 \%$ & 0 & $0 \%$ & 0 & $0 \%$ \\
\hline \multicolumn{9}{|c|}{ Activities and methods: teaching } \\
\hline & \multicolumn{2}{|c|}{$\begin{array}{c}\text { Not } \\
\text { observed }\end{array}$} & \multicolumn{2}{|c|}{ Inadequate } & \multicolumn{2}{|c|}{ Adequate } & \multicolumn{2}{|c|}{ Good } \\
\hline & $\mathrm{N}$ & $\%$ & $\mathrm{~N}$ & $\%$ & $\mathrm{~N}$ & $\%$ & $\mathrm{~N}$ & $\%$ \\
\hline $\begin{array}{l}\text { HV used the program educational } \\
\text { material } \\
\text { (manual/booklet) }\end{array}$ & 0 & $0 \%$ & 2 & $33.3 \%$ & 3 & $50 \%$ & 1 & $16.7 \%$ \\
\hline
\end{tabular}

\footnotetext{
${ }^{21}$ In La Libertad, the home visitors had teamed up with the National Institute of Technical Schools and attended workshops on craft making and toy making.
} 


\begin{tabular}{|c|c|c|c|c|c|c|c|c|}
\hline $\begin{array}{l}\text { HV had prepared for the visit in } \\
\text { advance }\end{array}$ & 2 & $33.3 \%$ & 0 & $0 \%$ & 0 & $0 \%$ & 4 & $66.7 \%$ \\
\hline $\begin{array}{lrr}\text { HV demonstrated } & \text { age- } \\
\text { appropriate activities } & \text { and } \\
\text { materials } & & \\
\end{array}$ & 1 & $16.7 \%$ & 1 & $16.7 \%$ & 1 & $16.7 \%$ & 3 & $50 \%$ \\
\hline $\begin{array}{l}\text { HV emphasized on language } \\
\text { development throughout the visit }\end{array}$ & 2 & $33.3 \%$ & 1 & $16.7 \%$ & 2 & $33.3 \%$ & 1 & $16.7 \%$ \\
\hline \multicolumn{9}{|c|}{ Activities and methods: explanation and demonstration } \\
\hline & \multicolumn{2}{|c|}{$\begin{array}{c}\text { Not } \\
\text { observed }\end{array}$} & \multicolumn{2}{|c|}{ Inadequate } & \multicolumn{2}{|c|}{ Adequate } & \multicolumn{2}{|c|}{ Good } \\
\hline & $\mathrm{N}$ & $\%$ & $\mathrm{~N}$ & $\%$ & $\mathrm{~N}$ & $\%$ & $\mathrm{~N}$ & $\%$ \\
\hline $\begin{array}{l}\text { HV's verbal explanation of } \\
\text { activities to the caregiver }\end{array}$ & 2 & $33.3 \%$ & 2 & $33.3 \%$ & 1 & $16.7 \%$ & 1 & $16.7 \%$ \\
\hline $\begin{array}{l}\text { HV's demonstration of activities } \\
\text { to the caregiver }\end{array}$ & 2 & $33.3 \%$ & 0 & $0 \%$ & 0 & $0 \%$ & 4 & $66.7 \%$ \\
\hline $\begin{array}{l}\text { HV's verbal explanation of } \\
\text { activities to the child }\end{array}$ & 2 & $33.3 \%$ & 0 & $0 \%$ & 3 & $50 \%$ & 1 & $16.7 \%$ \\
\hline $\begin{array}{l}\text { HV's demonstration of activities } \\
\text { to the child }\end{array}$ & 2 & $33.3 \%$ & 0 & $0 \%$ & 3 & $50 \%$ & 1 & $16.7 \%$ \\
\hline \multicolumn{9}{|c|}{ Activities and methods: participation } \\
\hline & \multicolumn{2}{|c|}{ Never } & \multicolumn{2}{|c|}{ Almost never } & \multicolumn{2}{|c|}{$\begin{array}{l}\text { Some of the } \\
\text { time }\end{array}$} & \multicolumn{2}{|c|}{$\begin{array}{l}\text { Most of the } \\
\text { time }\end{array}$} \\
\hline & $\mathrm{N}$ & $\%$ & $\mathrm{~N}$ & $\%$ & $\mathrm{~N}$ & $\%$ & $\mathrm{~N}$ & $\%$ \\
\hline $\begin{array}{l}\text { HV asked caregiver to practice } \\
\text { activities with child }\end{array}$ & 1 & $16.7 \%$ & 2 & $33.3 \%$ & 0 & $0 \%$ & 3 & $50 \%$ \\
\hline $\begin{array}{l}\text { HV reviewed activities with } \\
\text { caregiver at end of visit and } \\
\text { agreed on which activities } \\
\text { caregiver would practice between } \\
\text { visits }\end{array}$ & 1 & $16.7 \%$ & 2 & $33.3 \%$ & 0 & $0 \%$ & 3 & $50 \%$ \\
\hline \multicolumn{9}{|c|}{ Relationship between HV and caregiver } \\
\hline & \multicolumn{2}{|r|}{ Never } & \multicolumn{2}{|c|}{$\begin{array}{l}\text { Almost } \\
\text { never }\end{array}$} & \multicolumn{2}{|c|}{$\begin{array}{c}\text { Some of the } \\
\text { time }\end{array}$} & \multicolumn{2}{|c|}{$\begin{array}{l}\text { Most of the } \\
\text { time }\end{array}$} \\
\hline & $\mathrm{N}$ & $\%$ & $\mathrm{~N}$ & $\%$ & $\mathrm{~N}$ & $\%$ & $\mathrm{~N}$ & $\%$ \\
\hline HV listened to caregiver & 0 & $0 \%$ & 0 & $0 \%$ & 0 & $0 \%$ & 6 & $100 \%$ \\
\hline HV was responsive to caregiver & 0 & $0 \%$ & 0 & $0 \%$ & 0 & $0 \%$ & 6 & $100 \%$ \\
\hline $\begin{array}{l}\text { HV asked caregiver's opinion } \\
\text { lasked for questions throughout } \\
\text { the visit }\end{array}$ & 1 & $16.7 \%$ & 3 & $50 \%$ & 0 & $0 \%$ & 2 & $33.3 \%$ \\
\hline $\begin{array}{l}\text { HV encouraged and positively } \\
\text { reinforced the caregiver }\end{array}$ & 0 & $0 \%$ & 2 & $33.3 \%$ & 4 & $66.7 \%$ & 0 & $0 \%$ \\
\hline $\begin{array}{l}\text { Overall relationship between HV } \\
\text { and caregiver was warm and } \\
\text { supportive }\end{array}$ & 0 & $0 \%$ & 0 & $0 \%$ & 1 & $16.7 \%$ & 5 & $83.3 \%$ \\
\hline
\end{tabular}




\begin{tabular}{|c|c|c|c|c|c|c|c|c|}
\hline \multicolumn{9}{|c|}{ Relationship between HV and child } \\
\hline & \multicolumn{2}{|c|}{ Never } & \multicolumn{2}{|c|}{$\begin{array}{l}\text { Almost } \\
\text { never }\end{array}$} & \multicolumn{2}{|c|}{$\begin{array}{l}\text { Some of the } \\
\text { time }\end{array}$} & \multicolumn{2}{|c|}{$\begin{array}{l}\text { Most of the } \\
\text { time }\end{array}$} \\
\hline & $\mathrm{N}$ & $\%$ & $\mathrm{~N}$ & $\%$ & $\mathrm{~N}$ & $\%$ & $\mathrm{~N}$ & $\%$ \\
\hline $\begin{array}{l}\text { HV listened to child and } \\
\text { responded to his/her } \\
\text { vocalizations/gestures }\end{array}$ & 0 & $0 \%$ & 1 & $16.7 \%$ & 1 & $16.7 \%$ & 4 & $66.7 \%$ \\
\hline $\begin{array}{l}\text { HV praised child when he/she } \\
\text { attempted/completed an activity }\end{array}$ & 0 & $0 \%$ & 0 & $0 \%$ & 2 & $33.3 \%$ & 3 & $50 \%$ \\
\hline $\begin{array}{l}\text { HV talked about the activities the } \\
\text { child was doing throughout the } \\
\text { visit, or talked to child while child } \\
\text { did the activities }\end{array}$ & 2 & $33.3 \%$ & 0 & $0 \%$ & 3 & $50 \%$ & 1 & $16.7 \%$ \\
\hline $\begin{array}{l}\text { HV gave child enough time to } \\
\text { explore materials and complete } \\
\text { activities }\end{array}$ & 1 & $16.7 \%$ & 0 & $0 \%$ & 1 & $16.7 \%$ & 4 & $66.7 \%$ \\
\hline $\begin{array}{l}\text { Overall relationship between HV } \\
\text { and child was warm and } \\
\text { supportive }\end{array}$ & 0 & $0 \%$ & 1 & $16.7 \%$ & 1 & $16.7 \%$ & 4 & $66.7 \%$ \\
\hline \multicolumn{9}{|c|}{ Overall participation and atmosphere } \\
\hline & \multicolumn{2}{|c|}{ Never } & \multicolumn{2}{|c|}{$\begin{array}{l}\text { Almost } \\
\text { never }\end{array}$} & \multicolumn{2}{|c|}{$\begin{array}{l}\text { Some of the } \\
\text { time }\end{array}$} & \multicolumn{2}{|c|}{$\begin{array}{l}\text { Most of the } \\
\text { time }\end{array}$} \\
\hline & $\mathrm{N}$ & $\%$ & $\mathrm{~N}$ & $\%$ & $\mathrm{~N}$ & $\%$ & $\mathrm{~N}$ & $\%$ \\
\hline Child actively participated & 0 & $0 \%$ & 2 & $33.3 \%$ & 0 & $0 \%$ & 4 & $66.7 \%$ \\
\hline Caregiver actively participated & 0 & $0 \%$ & 2 & $33.3 \%$ & 1 & $16.7 \%$ & 3 & $50 \%$ \\
\hline $\begin{array}{l}\text { HV's made a significant effort to } \\
\text { encourage participation }\end{array}$ & 2 & $33.3 \%$ & 0 & $0 \%$ & 2 & $33.3 \%$ & 2 & $33.3 \%$ \\
\hline \multirow{2}{*}{ Overall atmosphere of the visit } & \multicolumn{2}{|c|}{ Uncomfortable } & \multicolumn{2}{|c|}{ Neutral } & \multicolumn{2}{|c|}{$\begin{array}{c}\text { Happy / } \\
\text { comfortable }\end{array}$} & \multicolumn{2}{|c|}{ Very happy } \\
\hline & 0 & $0 \%$ & 1 & $16.7 \%$ & 5 & $83.3 \%$ & 0 & $0 \%$ \\
\hline
\end{tabular}

Table 12: Program description: PAIPPI

\begin{tabular}{|l|l|}
\hline Name of the program & $\begin{array}{l}\text { Programa de Acompañamiento a la Implementación del } \\
\text { Programa de Primera Infancia en Comunidades } \\
\text { Priorizadas (PAIPPI) }\end{array}$ \\
\hline Number of beneficiary children & $\begin{array}{l}\sim 45,000 \text {. It's a national program, with coverage in 37 } \\
\text { urban and rural municipalities, selected for their high } \\
\text { poverty levels. }\end{array}$ \\
\hline Age range attended & Children aged 0 -6 years (focus is on 0 to 3 years) \\
\hline Visit frequency & $\begin{array}{l}\text { Children } 0-3 \text { years old: every 15 days } \\
\text { Children 4 -6 years: every 2 months }\end{array}$ \\
\hline Visit duration & 60 minutes \\
\hline
\end{tabular}




\begin{tabular}{|c|c|}
\hline $\begin{array}{l}\text { HV profile (education, experience, } \\
\text { remuneration) }\end{array}$ & $\begin{array}{l}\text { The majority of the home visitors have completed high } \\
\text { school, very few have completed technical or university } \\
\text { studies. Home visitors receive initial training from the } \\
\text { municipal technical supervisor in early childhood } \\
\text { development and visit methodology, from two days to one } \\
\text { week. Some home visitors are pre-school teachers. } \\
\text { They receive a monthly stipend equivalent to } 40 \text { USD. }\end{array}$ \\
\hline $\begin{array}{l}\text { Number of families per home } \\
\text { visitor }\end{array}$ & Each home visitor attends 25 families on average. \\
\hline $\begin{array}{l}\text { Curriculum: how is visit content } \\
\text { determined? }\end{array}$ & $\begin{array}{l}\text { The Curriculum Guide presents activities and learning } \\
\text { modules per age range, with defined activities described } \\
\text { for each visit (by child's age). The visit is supposed to } \\
\text { consist of } 6 \text { moments (although in the practice this rarely } \\
\text { happened): (1) Saludo a familia (family greeting } \\
\text { presentation of objectives), (2) Acompañamiento (review } \\
\text { of previous sessions and booklet), (3) Aplicación practica } \\
\text { (exercises and games with the child), (4) Promoción de } \\
\text { servicios (information about the program, and articulation } \\
\text { with health and education services), (5) Compartir los } \\
\text { logros (evaluation of the visit), (6) Acuerdos (agreement } \\
\text { about what activities/games/exercise caregiver will } \\
\text { implement during the following week. }\end{array}$ \\
\hline $\begin{array}{l}\text { Curriculum: is there a special } \\
\text { emphasis in } \\
\text { development? }\end{array}$ & $\begin{array}{l}\text { The focus is on holistic development, but home visitors } \\
\text { are instructed to discuss with caregivers the importance } \\
\text { of talking with child, naming objects, reading and looking } \\
\text { at books, etc. }\end{array}$ \\
\hline $\begin{array}{l}\text { Materials and manuals: What does } \\
\text { the home visitor bring with her to } \\
\text { the visit? }\end{array}$ & $\begin{array}{l}\text { Every home visitor receives a Tool Kit with the program } \\
\text { booklet, the Curriculum Guide (which still had yet to be } \\
\text { distributed), a towel and cushion to develop the visits } \\
\text { comfortably in the homes. The emphasis is on the use of } \\
\text { recursos de medio. }\end{array}$ \\
\hline $\begin{array}{l}\text { Supervision, monitoring and } \\
\text { support structure for home visitors }\end{array}$ & $\begin{array}{l}\text { Municipal technical supervisors are responsible for the } \\
\text { direct monitoring and supervision of the home visitors, } \\
\text { each is responsible for between } 3 \text { to } 10 \text { communities. } \\
\text { Some have experience in previous ECD programs, but } \\
\text { not all. In theory, all technical supervisors are supposed } \\
\text { to have participated in the Certification program in ECD, } \\
\text { but there has been a high level of rotation among } \\
\text { supervisors (and home visitors, see below). Technical } \\
\text { supervisors are responsible for all of the Ministry of the } \\
\text { Family's activities in the municipality, so they have many } \\
\text { other administrative and technical responsibilities in } \\
\text { addition to PAIPPI supervision. }\end{array}$ \\
\hline Visit preparation & $\begin{array}{l}\text { Home visitors should have a schedule written out for each } \\
\text { of the } 6 \text { visit moments, with activities and objectives } \\
\text { clearly defined. }\end{array}$ \\
\hline Time in implementation & 6 months (since October 2013). \\
\hline $\begin{array}{l}\text { Degree of rotation among home } \\
\text { visitors }\end{array}$ & $\begin{array}{l}\text { Prior to the initial launch of the program MIFAN conducted } \\
\text { a massive recruitment drive for home visitors, but a } \\
\text { significant portion have since deserted the program, since }\end{array}$ \\
\hline
\end{tabular}




\begin{tabular}{|l|l|}
\hline the central government eliminated the extra bonus they \\
had been distributing to public sector employees (about \\
10 USD per month that home visitors received in addition \\
to the 40 USD stipend). Also, during April and May many \\
municipalities did not distribute the 40 USD stipends due \\
to administrative backlogs, many home visitors left the \\
program.
\end{tabular}

\subsection{Ecuador: Creciendo con Nuestros Hijos ${ }^{22}$}

In Ecuador five visits of the program Creciendo con Nuestros Hijos (CNH) visits were observed, with four different home visitors, all of whom had at least 3 years of experience. Three different communities were visited: an urban area outside of Quito, a rural area outside of Santo Domingo (south of Quito), and an urban barrio of Santo Domingo.

In contrast to the other programs visited, CNH home visitors conduct only one activity per visit, and visits are shorter (about $\mathbf{3 0}$ minutes). Thus, each visit focuses on one development dimension: motor development, social development, or language development. This keeps visit content simple and clear, and also enables home visitors to visit many more families than in other programs (around 40/week). However, since each visit focuses on one particular dimension of development, language development is not emphasized as strongly as it perhaps should be, considering that in Ecuador, like most of the region, the most problematic developmental delays occur in language development. $\mathrm{CNH}$ home visitors do not talk about what the child is doing throughout the visit and do not often encourage the mother to remember to talk to the child, read and look at books with the child, name objects in the house, etc.

The visit consists of four moments, and this methodology was clearly followed in all of the visits observed: (1) Fase previa (family greeting, review of previous weeks activities), (2) Orientación (explication of the activity and why it is important), (3) Ejecución (caregiver and home visitor develop activity with the child), and (4) Control (evaluation of activity practiced and agreements about how caregiver and child will practice during the week). $\mathrm{CNH}$ does not include any type of booklet or reading material. Like Cuna Más, $\mathrm{CNH}$ families are encouraged to create play spaces in their homes, and like PAIPPI, CNH home visitors encourage families to create their own toys and play materials from existing resources.

$\mathrm{CNH}$ stands out in several ways. First, home visitors do a particularly good job of reviewing the previous week's activities with the caregiver. Beyond simply asking if she has been able to practice activities, home visitors always ask the caregiver to demonstrate the activity practiced, and the home visitor and caregiver then evaluate the child's improvements together. Second, home visitors achieve active, meaningful participation. They frequently ask the caregiver to review what has been discussed, asking, for example, "Why is this activity important? What is the

\footnotetext{
22 This program does not have an official website.
} 
purpose of this activity?" during both the review of the previous week's activity as well as the presentation of the current weeks activity. Also, home visitors ask the caregiver to evaluate the child's performance ("Did Nina easily solve this puzzle, or was it hard for her? How could we make it easy for her? How can we challenge her? What other objects could we introduce?"). This promotes dialogue throughout the visit and also means that, compared to other programs, $\mathbf{C N H}$ home visitors do an especially good job of explaining each activity's objective and ensuring that the caregiver understands why each activity has been selected.

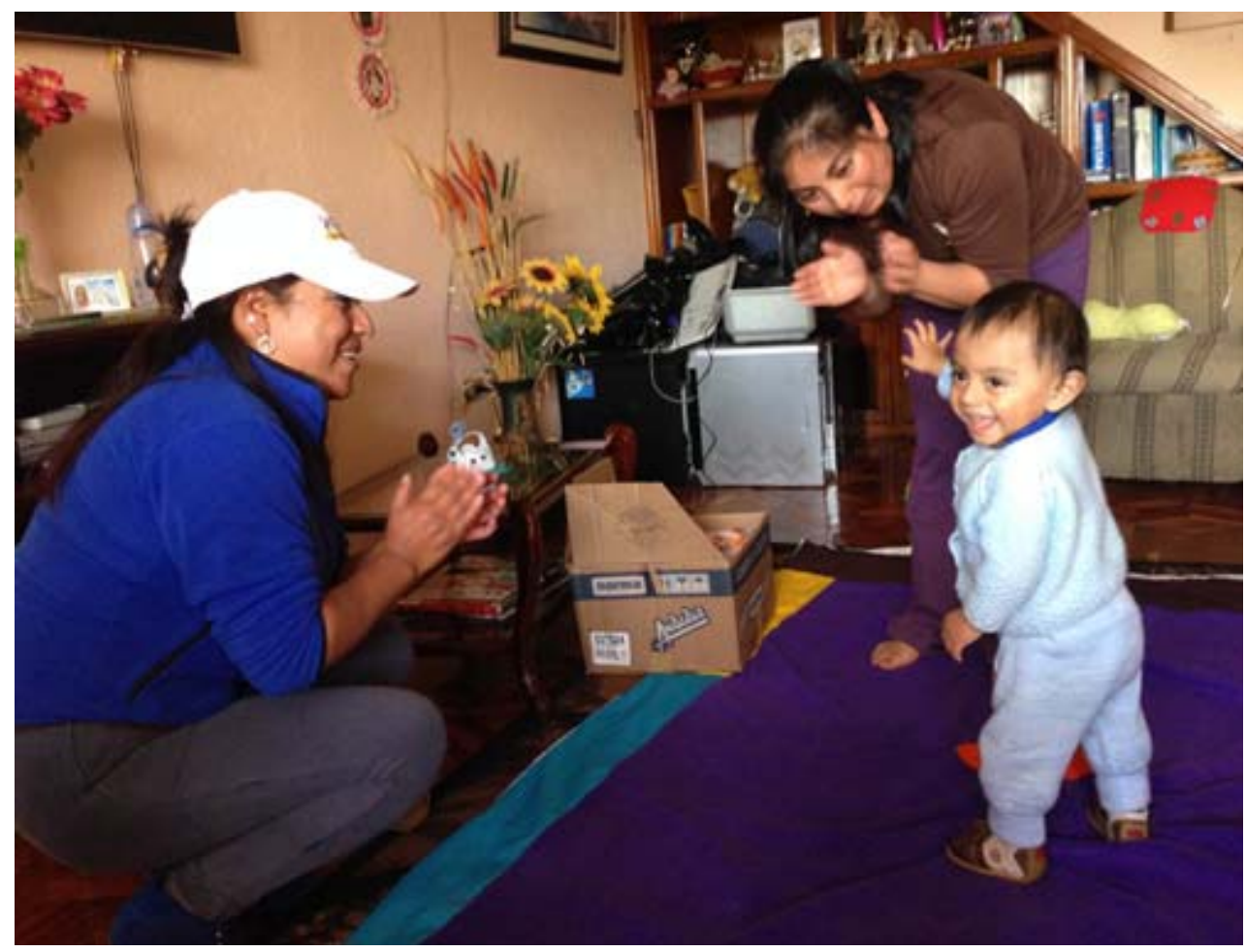

Home visitor (in white hat) with mother and child.

CNH also distributes a monthly magazine called Veo Veo with articles for the caregiver on ECD themes and also pictures, puzzles, and games for the children. The families visited spoke highly of CNH overall and also of the Veo Veo magazine.

Table 13: Score distribution: $\mathrm{CNH}$

\begin{tabular}{|l|c|c|c|c|c|c|c|c|}
\hline \multicolumn{1}{|c|}{ Description of activity } & \multicolumn{6}{|c|}{ Overall score distribution } \\
\hline \multicolumn{2}{|c|}{ Review of activities done since last visit } \\
\hline & \multicolumn{2}{|c|}{$\begin{array}{c}\text { Not } \\
\text { observed }\end{array}$} & \multicolumn{1}{|c|}{ Inadequate } & \multicolumn{2}{|c|}{ Adequate } & \multicolumn{2}{c|}{ Good } \\
\cline { 2 - 9 } & $\mathrm{N}$ & $\%$ & $\mathrm{~N}$ & $\%$ & $\mathrm{~N}$ & $\%$ & $\mathrm{~N}$ & $\%$ \\
\hline $\begin{array}{l}\text { HV asked caregiver about play } \\
\text { sessions between visit }\end{array}$ & 0 & $0 \%$ & 0 & $0 \%$ & 2 & $40 \%$ & 3 & $60 \%$ \\
\hline
\end{tabular}




\begin{tabular}{|c|c|c|c|c|c|c|c|c|}
\hline $\begin{array}{l}\mathrm{HV} \text { asked caregiver to } \\
\text { demonstrate w/child what had } \\
\text { been done since last visit }\end{array}$ & 0 & $0 \%$ & 1 & $20 \%$ & 2 & $20 \%$ & 3 & $60 \%$ \\
\hline \multicolumn{9}{|c|}{ Activities and methods: teaching } \\
\hline & \multicolumn{2}{|c|}{$\begin{array}{c}\text { Not } \\
\text { observed }\end{array}$} & \multicolumn{2}{|c|}{ Inadequate } & \multicolumn{2}{|c|}{ Adequate } & \multicolumn{2}{|c|}{ Good } \\
\hline & $\mathrm{N}$ & $\%$ & $\mathrm{~N}$ & $\%$ & $\mathrm{~N}$ & $\%$ & $\mathrm{~N}$ & $\%$ \\
\hline $\begin{array}{l}\text { HV had prepared for the visit in } \\
\text { advance }\end{array}$ & 0 & $0 \%$ & 0 & $0 \%$ & 1 & $20 \%$ & 4 & $80 \%$ \\
\hline $\begin{array}{lrr}\text { HV demonstrated } & \text { age- } \\
\text { appropriate activities } & \text { and } \\
\text { materials } & & \\
\end{array}$ & 0 & $0 \%$ & 0 & $0 \%$ & 2 & $40 \%$ & 3 & $60 \%$ \\
\hline $\begin{array}{l}\text { HV emphasized on language } \\
\text { development throughout the visit }\end{array}$ & 2 & $40 \%$ & 1 & $20 \%$ & 2 & $40 \%$ & 0 & $0 \%$ \\
\hline \multicolumn{9}{|c|}{ Activities and methods: explanation and demonstration } \\
\hline & \multicolumn{2}{|c|}{$\begin{array}{c}\text { Not } \\
\text { observed }\end{array}$} & \multicolumn{2}{|c|}{ Inadequate } & \multicolumn{2}{|c|}{ Adequate } & \multicolumn{2}{|c|}{ Good } \\
\hline & $\mathrm{N}$ & $\%$ & $\mathrm{~N}$ & $\%$ & $\mathrm{~N}$ & $\%$ & $\mathrm{~N}$ & $\%$ \\
\hline $\begin{array}{l}\text { HV's verbal explanation of } \\
\text { activities to the caregiver }\end{array}$ & 0 & $0 \%$ & 0 & $0 \%$ & 0 & $0 \%$ & 5 & $100 \%$ \\
\hline $\begin{array}{l}\text { HV's demonstration of activities } \\
\text { to the caregiver }\end{array}$ & 0 & $0 \%$ & 0 & $0 \%$ & 1 & $20 \%$ & 4 & $80 \%$ \\
\hline $\begin{array}{l}\text { HV's verbal explanation of } \\
\text { activities to the child }\end{array}$ & 0 & $0 \%$ & 0 & $0 \%$ & 5 & $80 \%$ & 1 & $20 \%$ \\
\hline $\begin{array}{l}\text { HV's demonstration of activities } \\
\text { to the child }\end{array}$ & 0 & $0 \%$ & 0 & $0 \%$ & 3 & $60 \%$ & 2 & $40 \%$ \\
\hline \multicolumn{9}{|c|}{ Activities and methods: participation } \\
\hline & \multicolumn{2}{|c|}{ Never } & \multicolumn{2}{|c|}{ Almost never } & \multicolumn{2}{|c|}{$\begin{array}{l}\text { Some of the } \\
\text { time }\end{array}$} & \multicolumn{2}{|c|}{$\begin{array}{l}\text { Most of the } \\
\text { time }\end{array}$} \\
\hline & $\mathrm{N}$ & $\%$ & $\mathrm{~N}$ & $\%$ & $\mathrm{~N}$ & $\%$ & $\mathrm{~N}$ & $\%$ \\
\hline $\begin{array}{l}\text { HV asked caregiver to practice } \\
\text { activities with child }\end{array}$ & 0 & $0 \%$ & 0 & $0 \%$ & 0 & $0 \%$ & 5 & $100 \%$ \\
\hline $\begin{array}{l}\text { HV reviewed activities with } \\
\text { caregiver at end of visit and } \\
\text { agreed on which activities } \\
\text { caregiver would practice between } \\
\text { visits }\end{array}$ & 0 & $0 \%$ & 0 & $0 \%$ & 0 & $0 \%$ & 5 & $100 \%$ \\
\hline \multicolumn{9}{|c|}{ Relationship between HV and caregiver } \\
\hline & \multicolumn{2}{|c|}{ Never } & \multicolumn{2}{|c|}{$\begin{array}{l}\text { Almost } \\
\text { never }\end{array}$} & \multicolumn{2}{|c|}{$\begin{array}{l}\text { Some of the } \\
\text { time }\end{array}$} & \multicolumn{2}{|c|}{$\begin{array}{l}\text { Most of the } \\
\text { time }\end{array}$} \\
\hline & $\mathrm{N}$ & $\%$ & $\mathrm{~N}$ & $\%$ & $\mathrm{~N}$ & $\%$ & $\mathrm{~N}$ & $\%$ \\
\hline HV listened to caregiver & 0 & $0 \%$ & 0 & $0 \%$ & 1 & $20 \%$ & 4 & $80 \%$ \\
\hline HV was responsive to caregiver & 0 & $0 \%$ & 0 & $0 \%$ & 2 & $40 \%$ & 3 & $60 \%$ \\
\hline $\begin{array}{l}\text { HV asked caregiver's opinion } \\
\text { lasked for questions throughout } \\
\text { the visit }\end{array}$ & 0 & $0 \%$ & 0 & $0 \%$ & 0 & $0 \%$ & 5 & $100 \%$ \\
\hline $\begin{array}{l}\text { HV encouraged and positively } \\
\text { reinforced the caregiver }\end{array}$ & 1 & $20 \%$ & 0 & $0 \%$ & 1 & $20 \%$ & 3 & $60 \%$ \\
\hline
\end{tabular}




\begin{tabular}{|c|c|c|c|c|c|c|c|c|}
\hline $\begin{array}{l}\text { Overall relationship between HV } \\
\text { and caregiver was warm and } \\
\text { supportive }\end{array}$ & 0 & $0 \%$ & 0 & $0 \%$ & 0 & $0 \%$ & 5 & $100 \%$ \\
\hline \multicolumn{9}{|c|}{ Relationship between HV and child } \\
\hline & \multicolumn{2}{|c|}{ Never } & \multicolumn{2}{|c|}{$\begin{array}{l}\text { Almost } \\
\text { never }\end{array}$} & \multicolumn{2}{|c|}{$\begin{array}{l}\text { Some of the } \\
\text { time }\end{array}$} & \multicolumn{2}{|c|}{$\begin{array}{l}\text { Most of the } \\
\text { time }\end{array}$} \\
\hline & $\mathrm{N}$ & $\%$ & $\mathrm{~N}$ & $\%$ & $\mathrm{~N}$ & $\%$ & $\mathrm{~N}$ & $\%$ \\
\hline $\begin{array}{lcl}\mathrm{HV} \text { listened to child and } \\
\text { responded } & \text { to } \\
\text { vocalizations/gestures }\end{array}$ & 0 & $0 \%$ & 1 & $20 \%$ & 0 & $0 \%$ & 4 & $80 \%$ \\
\hline $\begin{array}{l}\text { HV praised child when he/she } \\
\text { attempted/completed an activity }\end{array}$ & 0 & $0 \%$ & 0 & $0 \%$ & 1 & $20 \%$ & 4 & $80 \%$ \\
\hline $\begin{array}{l}\text { HV talked about the activities the } \\
\text { child was doing throughout the } \\
\text { visit, or talked to child while child } \\
\text { did the activities }\end{array}$ & 1 & $20 \%$ & 4 & $80 \%$ & 0 & $0 \%$ & 0 & $0 \%$ \\
\hline $\begin{array}{l}\text { HV gave child enough time to } \\
\text { explore materials and complete } \\
\text { activities }\end{array}$ & 0 & $0 \%$ & 0 & $0 \%$ & 0 & $0 \%$ & 5 & $100 \%$ \\
\hline $\begin{array}{l}\text { Overall relationship between HV } \\
\text { and child was warm and } \\
\text { supportive }\end{array}$ & 0 & $0 \%$ & 0 & $0 \%$ & 0 & $0 \%$ & 5 & $100 \%$ \\
\hline \multicolumn{9}{|c|}{ Overall participation and atmosphere } \\
\hline & \multicolumn{2}{|c|}{ Never } & \multicolumn{2}{|c|}{$\begin{array}{c}\text { Almost } \\
\text { never }\end{array}$} & \multicolumn{2}{|c|}{$\begin{array}{l}\text { Some of the } \\
\text { time }\end{array}$} & \multicolumn{2}{|c|}{$\begin{array}{l}\text { Most of the } \\
\text { time }\end{array}$} \\
\hline & $\mathrm{N}$ & $\%$ & $\mathrm{~N}$ & $\%$ & $\mathrm{~N}$ & $\%$ & $\mathrm{~N}$ & $\%$ \\
\hline Child actively participated & 0 & $0 \%$ & 0 & $0 \%$ & 2 & $40 \%$ & 3 & $60 \%$ \\
\hline Caregiver actively participated & 0 & $0 \%$ & 0 & $0 \%$ & 1 & $20 \%$ & 4 & $80 \%$ \\
\hline $\begin{array}{l}\text { HV's made a significant effort to } \\
\text { encourage participation }\end{array}$ & 0 & $0 \%$ & 0 & $0 \%$ & 2 & $40 \%$ & 3 & $60 \%$ \\
\hline \multirow[t]{2}{*}{ Overall atmosphere of the visit } & \multicolumn{2}{|c|}{ Uncomfortable } & \multicolumn{2}{|c|}{ Neutral } & \multicolumn{2}{|c|}{$\begin{array}{c}\text { Happy / } \\
\text { comfortable }\end{array}$} & \multicolumn{2}{|c|}{ Very happy } \\
\hline & 0 & $0 \%$ & 0 & $0 \%$ & 4 & $80 \%$ & 1 & $20 \%$ \\
\hline
\end{tabular}

Table 14: Program description: $\mathrm{CNH}$

\begin{tabular}{|l|l|}
\hline Name of the program & \multicolumn{1}{|c|}{ Creciendo con Nuestros Hijos (CNH) } \\
\hline Number of beneficiary children & $\begin{array}{l}200,400 \text { is the estimated coverage (including children } \\
\text { aged 0 to 3, but only children aged 0 to 2 receive home } \\
\text { visits). The actual coverage is not registered (there is no } \\
\text { system of coverage verification). }\end{array}$ \\
\hline Age range attended & $\begin{array}{l}\text { Children 0 to 2 years: home visits } \\
\text { Children 2 to 4: group sessions (with up to 8 families) }\end{array}$ \\
\hline Visit frequency & $\begin{array}{l}1 \text { visit per week. } \\
\text { Once a month home visitors conduct "control visits," in } \\
\text { which they ask caregivers to demonstrate the activities }\end{array}$ \\
\hline
\end{tabular}




\begin{tabular}{|c|c|}
\hline & $\begin{array}{l}\text { they have been practicing with their children, in order to } \\
\text { be sure that families are keeping up with commitments. }\end{array}$ \\
\hline Visit duration & About 30 minutes \\
\hline $\begin{array}{l}\text { Home visitor profile (education, } \\
\text { experience, remuneration) }\end{array}$ & $\begin{array}{l}\text { Home visitors used to be volunteers (with a stipend), but } \\
\text { when the state took control of the program in } 2012 / 13 \\
\text { all home visitors became public sector employees, with } \\
\text { full benefits and a salary of approximately } 700 \text { USD). } \\
\text { The education requirements were also raised, now home } \\
\text { visitors must have a professional degree (home visitors } \\
\text { w/out professional degree who were already incorporated } \\
\text { in the program were allowed to continue despite not } \\
\text { meeting this requirement). The state also offers continued } \\
\text { professional education for home visitors (certificates in } \\
\text { ECD). In some sectors professional degrees are rarer } \\
\text { and home visitors are accepted with only a high school } \\
\text { degree. }\end{array}$ \\
\hline & $\begin{array}{l}\text { Although these new requirements have been positive on } \\
\text { the whole, program coordinators emphasized that a } \\
\text { professional degree is not a guarantee of quality. Many } \\
\text { home visitors w/out degrees are much more competent } \\
\text { than their professional colleagues in terms of their ability } \\
\text { to work in the community, with families, under sometimes } \\
\text { difficult conditions. }\end{array}$ \\
\hline Number of families per home visitor & $\begin{array}{l}\text { Each home visitor attends } 60 \text { children (about } 30 \text { children } \\
\text { aged } 0 \text { to } 2 \text { and } 30 \text { children aged } 3 \text { to } 4 \text { ). However, CNH } \\
\text { has just changed its policy and now will attend only } \\
\text { children aged } 0 \text { to } 2 \text { (this is because the Ministry of } \\
\text { Education is assuming responsibility for children aged } 3 \\
\text { and up). This means that home visitors will take on new } \\
\text { families to maintain their } 60 \text { children minimum, but they } \\
\text { will be expected to conduct } 60 \text { home visits per week. } \\
\text { Coordinators and home visitors alike agree this will be } \\
\text { impossible, thus at the central level program staff are } \\
\text { evaluating new methodology, such as attending only } 0 \text { to } \\
1 \text { year olds through home visits and conducting group } \\
\text { sessions for } 2 \text { year olds. }\end{array}$ \\
\hline $\begin{array}{l}\text { Curriculum: how is visit content } \\
\text { determined? }\end{array}$ & $\begin{array}{l}\text { Visit planning is based on age, through a Planning Guide } \\
\text { or an Early Education Curriculum (there is a not a } \\
\text { standardized book for visit planning that all home visitors } \\
\text { use). Home visitors are responsible for defining their own } \\
\text { activities based on child's individual developmental status } \\
\text { and interests. }\end{array}$ \\
\hline $\begin{array}{l}\text { Curriculum: is there a special } \\
\text { emphasis } \\
\text { in } \\
\text { development? }\end{array}$ & There is no strong emphasis on language development. \\
\hline $\begin{array}{l}\text { Materials and manuals: What does } \\
\text { the home visitor bring with her to } \\
\text { the visit? }\end{array}$ & $\begin{array}{l}\text { Home visitors receive a Tool Kit with material to develop } \\
\text { their own toys and games. They are expected to come }\end{array}$ \\
\hline
\end{tabular}




\begin{tabular}{|c|c|}
\hline & $\begin{array}{l}\text { prepared for each visit with the toys and materials } \\
\text { necessary to develop the activity. }\end{array}$ \\
\hline $\begin{array}{l}\text { Supervision, monitoring and } \\
\text { support structure for home visitors }\end{array}$ & $\begin{array}{l}\text { The supervision structure is another challenge currently } \\
\text { facing CNH. Since the program restructuring in } 2012 / 13 \\
\text { the number of technical supervisors decreased from } 600 \\
\text { to } 40 \text {. There is only one technical supervisor per district; } \\
\text { each technical therefore is responsible for the direct } \\
\text { supervision of around } 200 \text { home visitors. } \\
\text { Some districts have been particularly creative in coming } \\
\text { up with solutions for this problem, organizing workshops } \\
\text { and demonstrations in groups and establishing } \\
\text { apprenticeship systems, whereby newly hired home } \\
\text { visitors shadow experienced home visitors. In other } \\
\text { districts home visitors have emerged as leaders and now } \\
\text { help technical supervisors with monitoring and } \\
\text { supervision activities. CNH coordinators are evaluating } \\
\text { how to formalize these mechanisms and practices. }\end{array}$ \\
\hline Visit preparation & $\begin{array}{l}\text { Home visitors should have all moments of the visit } \\
\text { planned and should be able explain the objective of each } \\
\text { activity in relation to child development. }\end{array}$ \\
\hline Time in implementation & $\begin{array}{l}18 \text { years (although program management and structure } \\
\text { has changed several times) }\end{array}$ \\
\hline $\begin{array}{l}\text { Degree of rotation among home } \\
\text { visitors }\end{array}$ & $\begin{array}{l}\text { Recently there has been a lot of rotation, due to the fact } \\
\text { that many of the newly hired professionals were not } \\
\text { happy with the sometimes difficult working conditions } \\
\text { (having to walk long distances between houses) and also } \\
\text { the instability of the current contract system (home } \\
\text { visitors are hired on a } 6 \text { month or year basis, and can earn } \\
\text { a significantly higher salary in other similar positions, } \\
\text { such as preschool teacher. }\end{array}$ \\
\hline
\end{tabular}

\subsection{Bolivia: Consejo de Salud Rural Andino ${ }^{23}$}

Unlike all other programs included in this study, the home visit program in Bolivia (nutrition program) is run by an NGO (Consejo de Salud Rural Andino - CSRA) and only operates in one municipality (El Alto). Thus, all six visits were observed in El Alto, an urban area located in the Andes mountains surrounding Bolivia's capitol, La Paz. Five different home visitors were observed, including one male home visitor.

\footnotetext{
${ }^{23}$ Detailed information on the program can be found in http://www.csra-bolivia.org/intro.php
} 


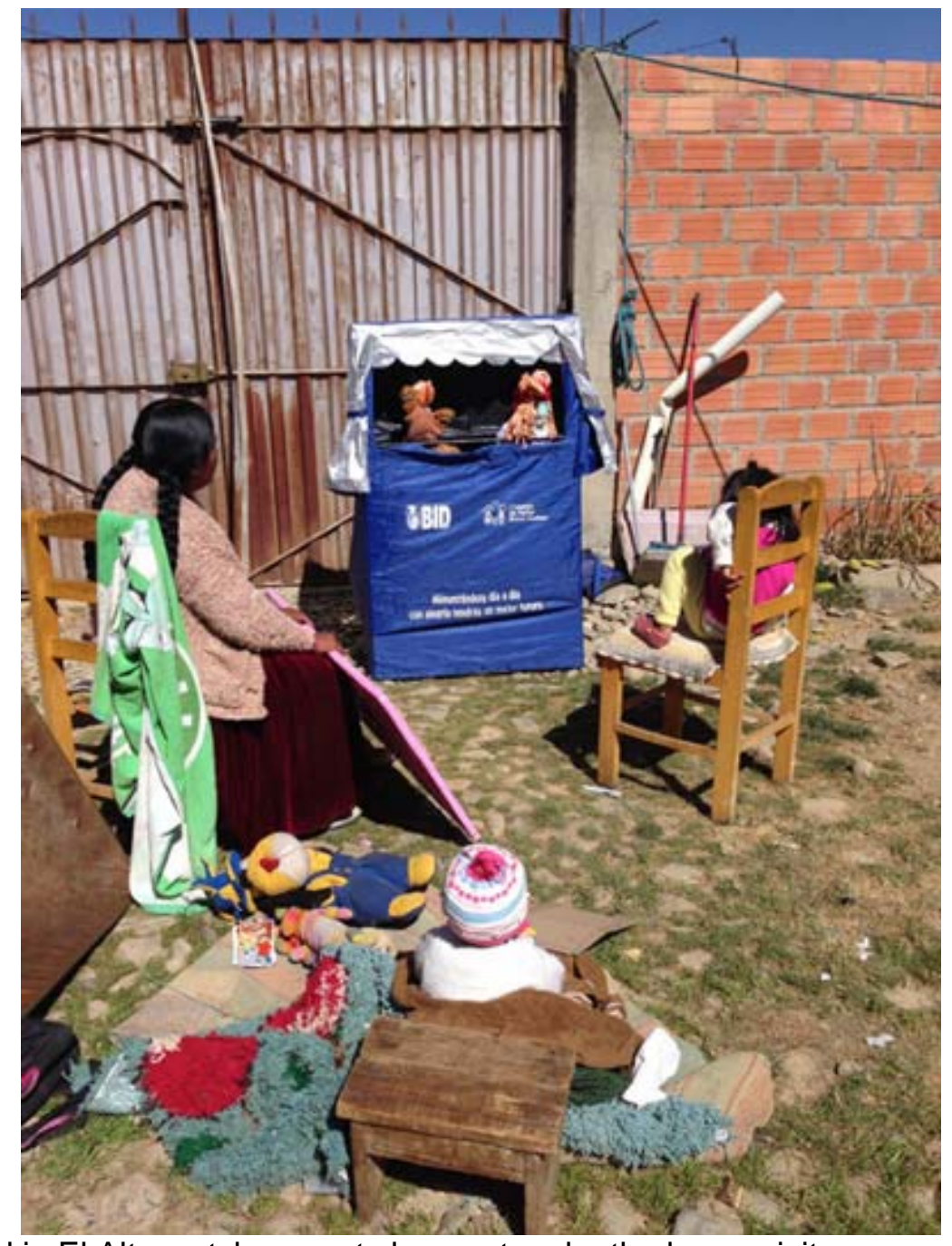

Mother and child in El Alto watch puppet show put on by the home visitor.

The CSRA program is also very new, it had only been in implementation for about two months at the time of fieldwork (end of June, 2014). Home visitors impart messages about healthy feeding practices through interactive puppet shows in which the character "La Cholita Marina" (the grandmother or awicha in Aymara) discusses her concerns regarding breast feeding, what types of food to feed her child, etc. The first few characters Marina encounters give her bad advice ("Junk food! Give your child junk food! It's cheap and tasty!"), and finally, after several encounters with "El Zorro" (or tiwula in Aymara) or other characters offering malicious or poorly informed advice, La Cholita Marina's own mother appears and offers good advice ("No! Don't listen to the wolf! Your child needs protein, lots of protein, not junk food!').

Each family has a foam board with the child's name at the top and pockets to insert recipes, images of healthy feeding practices, and pictures of the child. In addition to feeding practices, home visitors emphasize the importance of hand washing. Some home visitors also discuss the importance of interacting with their children during mealtime, although this message was not 
as strong as others. Home visitors focus on one specific message per visit (appropriate frequency of feeding, portion size, food types, or food consistency, among others).

Home visitors received extensive training in theater and participatory education, and all home visitors observed consistently incorporated the caregiver and child into the dialogue with the characters during the puppet show. After the puppet show, home visitors discuss the topics covered with the caregiver and help her choose which feeding practices she will implement during the week. In general, home visitors were very good at the puppet show part of the visit, but could do more to encourage participation during the discussion part of the visit. That is, beyond asking the caregiver to repeat what happened in the puppet show ("What was Marina worried about this time? What advice did she get?"), home visitors could help the caregiver think about different ways she can implement the feeding practices discussed in the puppet show, or ask her what she would do if she were Marina, for example (some home visitors did do this, but not all).

Table 15: Score distribution: CSRA

\begin{tabular}{|c|c|c|c|c|c|c|c|c|}
\hline Description of activity & \multicolumn{8}{|c|}{ Overall score distribution } \\
\hline \multicolumn{9}{|c|}{ Review of activities done since last visit } \\
\hline & \multicolumn{2}{|c|}{$\begin{array}{c}\text { Not } \\
\text { observed }\end{array}$} & \multicolumn{2}{|c|}{ Inadequate } & \multicolumn{2}{|c|}{ Adequate } & \multicolumn{2}{|c|}{ Good } \\
\hline & $\mathrm{N}$ & $\%$ & N & $\%$ & $\mathrm{~N}$ & $\%$ & $\mathrm{~N}$ & $\%$ \\
\hline $\begin{array}{l}\text { HV followed up with caregiver } \\
\text { about feeding practices they had } \\
\text { discussed during the previous } \\
\text { visit }\end{array}$ & 0 & $0 \%$ & 1 & $16.7 \%$ & 3 & $50 \%$ & 1 & $16.7 \%$ \\
\hline \multicolumn{9}{|c|}{ Activities and methods: Teaching \& participation } \\
\hline & \multicolumn{2}{|c|}{$\begin{array}{l}\text { None/not at } \\
\text { all }\end{array}$} & \multicolumn{2}{|c|}{ Inadequate } & \multicolumn{2}{|c|}{ Adequate } & \multicolumn{2}{|c|}{ Good } \\
\hline & $\mathrm{N}$ & $\%$ & $\mathrm{~N}$ & $\%$ & $\mathrm{~N}$ & $\%$ & $\mathrm{~N}$ & $\%$ \\
\hline $\begin{array}{l}\mathrm{HV} \text { had prepared for the visit in } \\
\text { advance }\end{array}$ & 0 & $0 \%$ & 0 & $0 \%$ & 4 & $66.7 \%$ & 2 & $33.3 \%$ \\
\hline $\begin{array}{lr}\text { HV used the program educational } \\
\text { material } & \text { appropriately } \\
\text { (manual/booklet) } & \end{array}$ & 0 & $0 \%$ & 0 & $0 \%$ & 4 & $66.7 \%$ & 2 & $33.3 \%$ \\
\hline $\begin{array}{l}\text { HV provided strong explanations } \\
\text { and motivations for healthy } \\
\text { feeding practices }\end{array}$ & 1 & $16.7 \%$ & 0 & $0 \%$ & 0 & $0 \%$ & 4 & $66.7 \%$ \\
\hline $\begin{array}{l}\text { HV reviewed feeding practices } \\
\text { with caregiver at end of visit and } \\
\text { agreed on which practices } \\
\text { caregiver would focus on } \\
\text { between visits }\end{array}$ & 0 & $0 \%$ & 0 & $0 \%$ & 1 & $16.7 \%$ & 5 & $83.3 \%$ \\
\hline
\end{tabular}




\begin{tabular}{|c|c|c|c|c|c|c|c|c|}
\hline $\begin{array}{l}\text { Topics discussed were age } \\
\text { appropriate }\end{array}$ & 0 & $0 \%$ & b & $0 \%$ & 0 & $0 \%$ & 6 & $100 \%$ \\
\hline \multicolumn{9}{|c|}{ Relationship between HV and caregiver } \\
\hline & \multicolumn{2}{|c|}{ Never } & \multicolumn{2}{|c|}{$\begin{array}{c}\text { Almost } \\
\text { never }\end{array}$} & \multicolumn{2}{|c|}{$\begin{array}{l}\text { Some of the } \\
\text { time }\end{array}$} & \multicolumn{2}{|c|}{$\begin{array}{l}\text { Most of the } \\
\text { time }\end{array}$} \\
\hline & $\mathrm{N}$ & $\%$ & $\mathrm{~N}$ & $\%$ & $\mathrm{~N}$ & $\%$ & $\mathrm{~N}$ & $\%$ \\
\hline HV listened to caregiver & 0 & $0 \%$ & 0 & $0 \%$ & 0 & $0 \%$ & 6 & $100 \%$ \\
\hline HV was responsive to caregiver & 0 & $0 \%$ & 0 & $0 \%$ & 1 & $16.7 \%$ & 5 & $83.3 \%$ \\
\hline $\begin{array}{l}\text { HV asked caregiver's opinion } \\
\text { lasked for questions throughout } \\
\text { the visit }\end{array}$ & 0 & $0 \%$ & 0 & $0 \%$ & 2 & $33.3 \%$ & 4 & $66.7 \%$ \\
\hline $\begin{array}{l}\text { HV encouraged and positively } \\
\text { reinforced the caregiver }\end{array}$ & 0 & $0 \%$ & 0 & $0 \%$ & 0 & $0 \%$ & 6 & $100 \%$ \\
\hline $\begin{array}{l}\text { Overall relationship between HV } \\
\text { and caregiver was warm and } \\
\text { supportive }\end{array}$ & 0 & $0 \%$ & 0 & $0 \%$ & 0 & $0 \%$ & 6 & $100 \%$ \\
\hline \multicolumn{9}{|c|}{ Overall participation and atmosphere } \\
\hline & \multicolumn{2}{|c|}{ Never } & \multicolumn{2}{|c|}{$\begin{array}{l}\text { Almost } \\
\text { never }\end{array}$} & \multicolumn{2}{|c|}{$\begin{array}{l}\text { Some of the } \\
\text { time }\end{array}$} & \multicolumn{2}{|c|}{$\begin{array}{l}\text { Most of the } \\
\text { time }\end{array}$} \\
\hline & $\mathrm{N}$ & $\%$ & $\mathrm{~N}$ & $\%$ & $\mathrm{~N}$ & $\%$ & $\mathrm{~N}$ & $\%$ \\
\hline Caregiver actively participated & 0 & $0 \%$ & 0 & $0 \%$ & 2 & $33.3 \%$ & 4 & $66.7 \%$ \\
\hline $\begin{array}{l}\text { HV's overall effort to encourage } \\
\text { participation }\end{array}$ & 0 & $0 \%$ & 0 & $0 \%$ & 1 & $16.7 \%$ & 5 & $83.3 \%$ \\
\hline \multirow{2}{*}{$\begin{array}{l}\text { Overall atmosphere of the visit } \\
\text { was warm and cooperative }\end{array}$} & \multicolumn{2}{|c|}{ Uncomfortable } & \multicolumn{2}{|c|}{ Neutral } & \multicolumn{2}{|c|}{$\begin{array}{c}\text { Happy / } \\
\text { comfortable }\end{array}$} & \multicolumn{2}{|c|}{ Very happy } \\
\hline & 0 & $0 \%$ & 0 & $0 \%$ & 6 & $100 \%$ & 0 & $0 \%$ \\
\hline
\end{tabular}


Table 16: Program description: CRSA

\begin{tabular}{|c|c|}
\hline Name of the program & $\begin{array}{l}\text { Consejo de Salud Rural Andino - CSRA is the executing } \\
\text { agency, the program itself does not have a specific name. }\end{array}$ \\
\hline Number of beneficiary children & 1,000 \\
\hline Age range attended & Expecting mothers and children aged 0 to 2 \\
\hline Visit frequency & $\begin{array}{l}\text { Expecting mothers and children aged } 0 \text { to } 12 \text { months: } \\
\text { every } 15 \text { days } \\
\text { Children aged } 13 \text { to } 24 \text { months: monthly visits }\end{array}$ \\
\hline Visit duration & 30 minutes \\
\hline $\begin{array}{l}\text { HV profile (education, experience, } \\
\text { remuneration) }\end{array}$ & $\begin{array}{l}\text { All home visitors are professionals in the fields of health, } \\
\text { nutrition and medicine; most have previous experience as } \\
\text { community health workers. } \\
\text { All received extensive training in maternal and infant } \\
\text { health and nutrition, social work, theater, and } \\
\text { participatory education methods. } \\
\text { All are full time employees of CSRA. }\end{array}$ \\
\hline Number of families per home visitor & Each attends 90 families. \\
\hline $\begin{array}{l}\text { Curriculum: how is visit content } \\
\text { determined? }\end{array}$ & $\begin{array}{l}\text { Messages are defined based on the age range of the } \\
\text { child. Home visitors are expected to be able to evaluate } \\
\text { the particular needs of the family/child to determine visit } \\
\text { content. }\end{array}$ \\
\hline $\begin{array}{l}\text { Materials and manuals: What does } \\
\text { the home visitor bring with her to } \\
\text { the visit? }\end{array}$ & $\begin{array}{l}\text { In addition to the folding puppet show stand and puppets, } \\
\text { home visitors help the families decorate the poster with } \\
\text { the child's name, picture, "tasks" for the weeks feeding } \\
\text { practices, and principal messages about the family's } \\
\text { goals for the child (i.e., to become a doctor, teacher, } \\
\text { lawyer, etc.). }\end{array}$ \\
\hline $\begin{array}{l}\text { Supervision, monitoring and } \\
\text { support structure for home visitors }\end{array}$ & $\begin{array}{l}\text { Home visitors meet daily in the headquarters of CSRA to } \\
\text { go over visit planning and register family data collected } \\
\text { (register of families visited and their situation). } \\
\text { Supervisors and coordinators are always present to help } \\
\text { home visitors plan and to go over issues. In addition, } \\
\text { supervisors conduct random observations of the home } \\
\text { visits and also visit families to enquire about their } \\
\text { satisfaction with the program. There are } 2 \text { full time } \\
\text { supervisors (for } 11 \text { home visitors in total). }\end{array}$ \\
\hline Visit preparation & $\begin{array}{l}\text { Home visitors should have all materials for the puppet } \\
\text { show, should have practiced or at least planned the } \\
\text { puppet show, and also be prepared to discuss advances } \\
\text { and follow up with the caregiver. }\end{array}$ \\
\hline Time in implementation & $\begin{array}{l}\text { The home visits started in April, } 2014 \text { ( } 2 \text { months of } \\
\text { implementation at the time of fieldwork). }\end{array}$ \\
\hline $\begin{array}{l}\text { Degree of rotation among home } \\
\text { visitors }\end{array}$ & Very low. \\
\hline
\end{tabular}




\subsection{Panamá: Atención Integral a de la Niñez con Participación Comunitaria (AIN-C) ${ }^{24}$}

In Panama all visits observed took place in the Kuna indigenous community of the San Blas (Kuna Yala) archipelago in Panama's Caribbean coast. AIN-C is a more traditional home visit program; home visitors weigh the child and discuss feeding and nutrition practices with the mother. Two visits were observed on one island and three visits on another, slightly larger, neighboring island (5 different home visitors).

Quality varied significantly between the two islands. The first island visited was smaller and the home visitors operate with very limited supervision. The island does not have its own health center, so home visitors report to the nearby island. When weighing the children, the home visitors on the first island did not ask for the caregiver's permission or help, and also did not inform her of the child's weight and growth tendency. Furthermore, they had to be reminded to continue the visit after weighing the child, it's not clear if home visitors on this island consistently implement the counseling part of the visit. Staff from Ministry of Health (MINSA), has also documented lack of interaction and passivity of caregivers during the visits which is aligned with the findings here.

The situation was much different on the second, slightly larger, island. Here, the group of home visitors was tightknit and also very young (between 17 and 26). There is a health center on the island where the home visitors store their materials, and the health center doctor also provides (limited) support in terms of supervision and monitoring. A nutritionist had also previously been stationed full time on the island to provide on-going support to the home visitors. Finally, one home visitor had emerged as the leader of the group, home visitors referred to her for help with planning and organization and she made sure that the program continued after the departure of the nutritionist.

The home visitors on the second island took the child weights correctly, asking for the caregiver's permission and help, informing her of the child's weight and discussing child's growth patterns. Afterwards they sat down with the caregiver to go over the program material (slides with images of feeding practices); asking her opinion throughout the visit and helping her select which new feeding practices to implement.

24 This program does not have an official website. 
Table 17: Score distribution: AIN-C

\begin{tabular}{|c|c|c|c|c|c|c|c|c|}
\hline Description of activity & \multicolumn{8}{|c|}{ Overall score distribution } \\
\hline \multicolumn{9}{|c|}{ Review of activities done since last visit } \\
\hline & \multicolumn{2}{|c|}{$\begin{array}{c}\text { Not } \\
\text { observed }\end{array}$} & \multicolumn{2}{|c|}{ Inadequate } & \multicolumn{2}{|c|}{ Adequate } & \multicolumn{2}{|c|}{ Good } \\
\hline & $\mathrm{N}$ & $\%$ & $\mathrm{~N}$ & $\%$ & $\mathrm{~N}$ & $\%$ & $\mathrm{~N}$ & $\%$ \\
\hline $\begin{array}{l}\text { HV followed up with caregiver } \\
\text { about feeding practices they had } \\
\text { discussed during the previous } \\
\text { visit }\end{array}$ & 5 & $100 \%$ & 0 & $0 \%$ & 0 & $0 \%$ & 0 & $0 \%$ \\
\hline \multicolumn{9}{|c|}{ Weight measurement } \\
\hline & \multicolumn{2}{|c|}{$\begin{array}{c}\text { Not } \\
\text { observed }\end{array}$} & \multicolumn{2}{|c|}{ Inadequate } & \multicolumn{2}{|c|}{ Adequate } & \multicolumn{2}{|c|}{ Good } \\
\hline & $\mathrm{N}$ & $\%$ & $\mathrm{~N}$ & $\%$ & $\mathrm{~N}$ & $\%$ & $\mathrm{~N}$ & $\%$ \\
\hline $\begin{array}{l}\text { HV demonstrated correct } \\
\text { procedure when weighing child }\end{array}$ & 0 & $0 \%$ & 2 & $40 \%$ & 0 & $0 \%$ & 3 & $60 \%$ \\
\hline $\begin{array}{l}\text { HV informed the caregiver of the } \\
\text { child's weight \& explained growth } \\
\text { pattern }\end{array}$ & 2 & $40 \%$ & 0 & $0 \%$ & 2 & $40 \%$ & 1 & $20 \%$ \\
\hline \multicolumn{9}{|c|}{ Activities and methods: Teaching \& participation } \\
\hline & \multicolumn{2}{|c|}{$\begin{array}{l}\text { None/not at } \\
\text { all }\end{array}$} & \multicolumn{2}{|c|}{ Inadequate } & \multicolumn{2}{|c|}{ Adequate } & \multicolumn{2}{|c|}{ Good } \\
\hline & $\mathrm{N}$ & $\%$ & $\mathrm{~N}$ & $\%$ & $\mathrm{~N}$ & $\%$ & $\mathrm{~N}$ & $\%$ \\
\hline $\begin{array}{l}\text { HV had prepared for the visit in } \\
\text { advance }\end{array}$ & 1 & $20 \%$ & 0 & $0 \%$ & 3 & $60 \%$ & 1 & $20 \%$ \\
\hline $\begin{array}{l}\text { HV used the program educational } \\
\text { material } \\
\begin{array}{ll}\text { (manual/booklet) } & \text { appropriately }\end{array} \\
\end{array}$ & 0 & $0 \%$ & 1 & $20 \%$ & 1 & $20 \%$ & 3 & $60 \%$ \\
\hline $\begin{array}{l}\text { HV provided strong explanations } \\
\text { and motivations for healthy } \\
\text { feeding practices }\end{array}$ & 1 & $20 \%$ & 2 & $20 \%$ & 0 & $0 \%$ & 4 & $3 \%$ \\
\hline $\begin{array}{l}\text { HV reviewed feeding practices } \\
\text { with caregiver at end of visit and } \\
\text { agreed on which practices } \\
\text { caregiver would focus on } \\
\text { between visits }\end{array}$ & 1 & $20 \%$ & 0 & $0 \%$ & 1 & $20 \%$ & 3 & $60 \%$ \\
\hline $\begin{array}{l}\text { Topics discussed were age } \\
\text { appropriate }\end{array}$ & 0 & $0 \%$ & 0 & $0 \%$ & 0 & $0 \%$ & 5 & $100 \%$ \\
\hline \multicolumn{9}{|c|}{ Relationship between HV and caregiver } \\
\hline & \multicolumn{2}{|c|}{ Never } & \multicolumn{2}{|c|}{$\begin{array}{l}\text { Almost } \\
\text { never }\end{array}$} & \multicolumn{2}{|c|}{$\begin{array}{l}\text { Some of the } \\
\text { time }\end{array}$} & \multicolumn{2}{|c|}{$\begin{array}{l}\text { Most of the } \\
\text { time }\end{array}$} \\
\hline & $\mathrm{N}$ & $\%$ & $\mathrm{~N}$ & $\%$ & $\mathrm{~N}$ & $\%$ & $\mathrm{~N}$ & $\%$ \\
\hline HV listened to caregiver & 0 & $0 \%$ & 0 & $0 \%$ & 2 & $40 \%$ & 3 & $60 \%$ \\
\hline HV was responsive to caregiver & 0 & $0 \%$ & 2 & $40 \%$ & 0 & $0 \%$ & 3 & $60 \%$ \\
\hline
\end{tabular}




\begin{tabular}{|c|c|c|c|c|c|c|c|c|}
\hline $\begin{array}{l}\text { HV asked caregiver's opinion } \\
\text { lasked for questions throughout } \\
\text { the visit }\end{array}$ & 1 & $20 \%$ & 0 & $0 \%$ & 4 & $80 \%$ & 0 & $0 \%$ \\
\hline $\begin{array}{l}\text { HV encouraged and positively } \\
\text { reinforced the caregiver }\end{array}$ & 2 & $40 \%$ & 2 & $40 \%$ & 1 & $20 \%$ & 0 & $0 \%$ \\
\hline $\begin{array}{l}\text { Overall relationship between HV } \\
\text { and caregiver was warm and } \\
\text { supportive }\end{array}$ & 0 & $0 \%$ & 1 & $20 \%$ & 2 & $40 \%$ & 2 & $40 \%$ \\
\hline \multicolumn{9}{|c|}{ Overall participation and atmosphere } \\
\hline & \multicolumn{2}{|c|}{ Never } & \multicolumn{2}{|c|}{$\begin{array}{c}\text { Almost } \\
\text { never }\end{array}$} & \multicolumn{2}{|c|}{$\begin{array}{l}\text { Some of the } \\
\text { time }\end{array}$} & \multicolumn{2}{|c|}{$\begin{array}{l}\text { Most of the } \\
\text { time }\end{array}$} \\
\hline & $\mathrm{N}$ & $\%$ & $\mathrm{~N}$ & $\%$ & $\mathrm{~N}$ & $\%$ & $\mathrm{~N}$ & $\%$ \\
\hline Caregiver actively participated & 0 & $0 \%$ & 2 & $40 \%$ & 0 & $0 \%$ & 3 & $60 \%$ \\
\hline $\begin{array}{l}\text { HV's overall effort to encourage } \\
\text { participation }\end{array}$ & 0 & $0 \%$ & 2 & $40 \%$ & 3 & $60 \%$ & 0 & $0 \%$ \\
\hline \multirow{2}{*}{$\begin{array}{l}\text { Overall atmosphere of the visit } \\
\text { was warm and cooperative }\end{array}$} & \multicolumn{2}{|c|}{$\begin{array}{c}\text { Uncomfortabl } \\
\mathrm{e}\end{array}$} & \multicolumn{2}{|c|}{ Neutral } & \multicolumn{2}{|c|}{$\begin{array}{l}\text { Happy/comfo } \\
\text { rtable }\end{array}$} & \multicolumn{2}{|c|}{ Very happy } \\
\hline & 0 & $0 \%$ & 2 & $40 \%$ & 3 & $60 \%$ & 0 & $0 \%$ \\
\hline
\end{tabular}

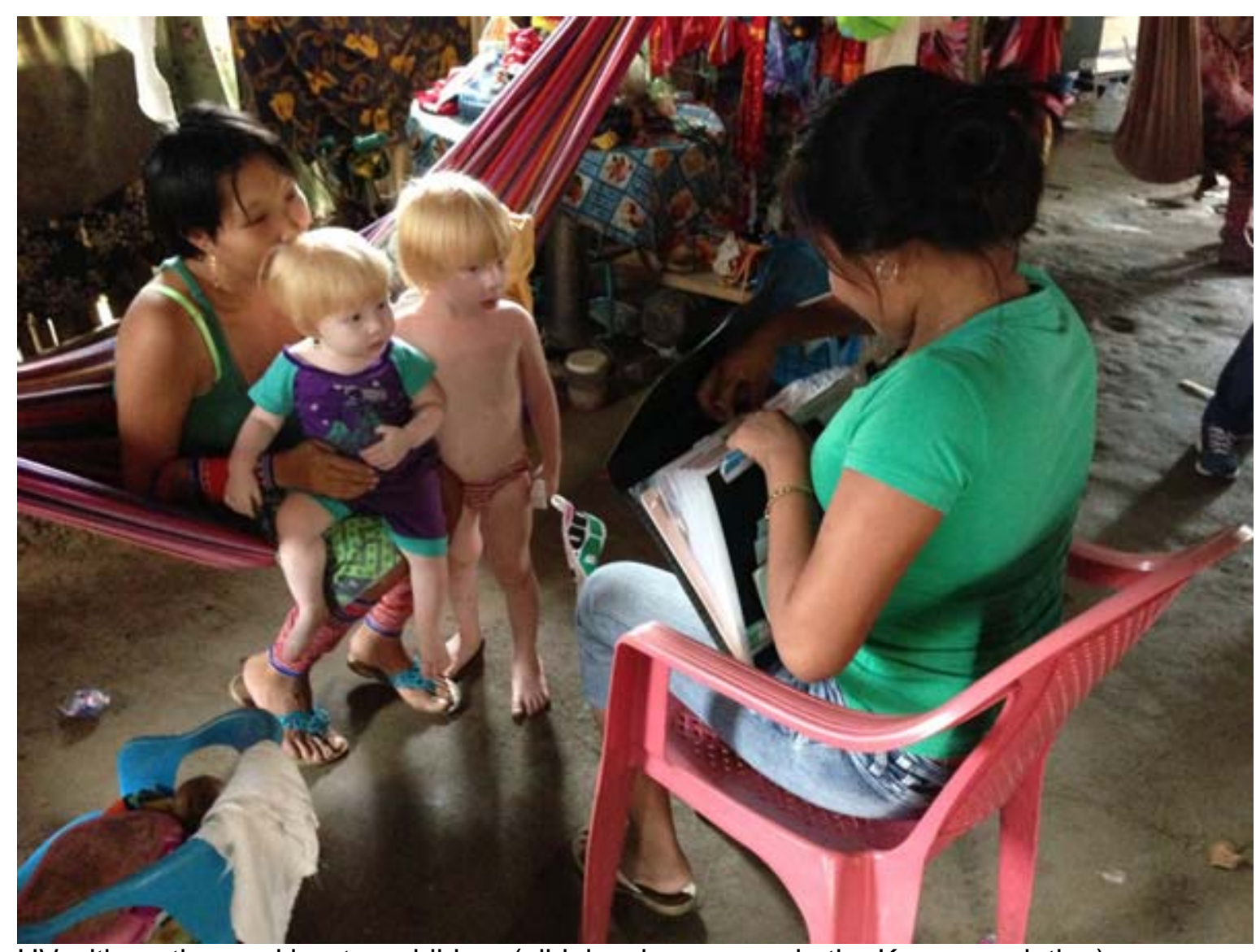

$\mathrm{HV}$ with mother and her two children (albinism is common in the Kuna population). 
Table 18: Program description: AIN-C

\begin{tabular}{|c|c|}
\hline Name of the program & $\begin{array}{l}\text { Atención Integral de La Niñez a Nivel Comunitaria (AIN- } \\
\text { C) }\end{array}$ \\
\hline Number of beneficiary children & 1,200 children (estimated coverage) \\
\hline Age range attended & Children 2 years old and younger \\
\hline Visit frequency & Monthly \\
\hline Visit duration & 1 hour \\
\hline $\begin{array}{l}\text { HV profile (education, experience, } \\
\text { remuneration) }\end{array}$ & $\begin{array}{l}\text { Home visitors are female volunteers selected by the } \\
\text { community. They must know how to read and write, be at } \\
\text { least } 16 \text { years old, and have someone in the community } \\
\text { who can take care of their own children while they } \\
\text { conduct home visits (if relevant). } \\
\text { They receive an initial training of } 5 \text { full days in ECD and } \\
\text { nutrition and visit methodology. } \\
\text { Home visitors are volunteers, although they receive } 25 \\
\text { USD per month to help with transportation costs. }\end{array}$ \\
\hline Number of families per home visitor & $8-12$ families per home visitor \\
\hline $\begin{array}{l}\text { Curriculum: how is visit content } \\
\text { determined? }\end{array}$ & $\begin{array}{l}\text { The child's weight is taken in each visit. In terms of } \\
\text { counseling, the visit content is determined by the program } \\
\text { slides - the home visitor shows the mother the slides (by } \\
\text { age range) and she selects the images that portray the } \\
\text { feeding practices she implements or the current } \\
\text { nutritional status of her child. With this information, the } \\
\text { home visitor selects the correct slide to use for the } \\
\text { informational (counseling) part of the visit. }\end{array}$ \\
\hline $\begin{array}{l}\text { Materials and manuals: What does } \\
\text { the home visitor bring with her to } \\
\text { the visit? }\end{array}$ & $\begin{array}{l}\text { 1. Program Manual } \\
\text { 2. Slides for counseling } \\
\text { 3. Register of weight and visit information } \\
\text { 4. Balance and other materials necessary for taking } \\
\text { child's weight (including growth chart) }\end{array}$ \\
\hline Supervision structure & $\begin{array}{l}\text { There should be one nutritionist per "population group" in } \\
\text { charge of the direct supervision (at least } 1 \times / \text { month) of } \\
\text { home visitors- but many nutritionists have left the } \\
\text { program (due to issues with age payments). } \\
\text { Regional supervisors and coordinators conduct bimonthly } \\
\text { supervision rounds and refresher trainings. } \\
\text { AIN-C is facing serious challenges in terms of supervision } \\
\text { and monitoring (delays in payments of per diems for } \\
\text { supervision trips, delays in wage distribution for } \\
\text { supervisors and nutritionists). Thus, supervision seems to } \\
\text { happen at an ad hoc basis, and is made much more } \\
\text { difficult by the fact that the Kuna Yala community is } \\
\text { particularly hard to access and costly (all supervision } \\
\text { visits require travel by boat across large distances). }\end{array}$ \\
\hline
\end{tabular}




\begin{tabular}{|l|l|}
\hline Visit preparation & $\begin{array}{l}\text { Home visitors should have all materials ready and be } \\
\text { prepared to provide individualized information for the } \\
\text { caregiver }\end{array}$ \\
\hline Time in implementation & About 1 year, program started in May, 2013 \\
\hline \multirow{2}{*}{$\begin{array}{l}\text { Degree of rotation among home } \\
\text { visitors }\end{array}$} & $\begin{array}{l}2013 \text { - aprox. 20\% left the program } \\
2014-\text { aprox. 40\% left the program } \\
\text { This is largely due to delays in the per-diem payments } \\
\text { (administrative backlogs). In many communities it has } \\
\text { been hard to find replacement home visitors. }\end{array}$ \\
\hline
\end{tabular}

\section{Conclusions}

This study provides up-to-date data on the quality of home visit child development and nutrition parenting programs in the LAC region. This unique "snap-shot" of seven prominent home visit programs finds that home visitors are generally successful at establishing strong rapport with families, covering age appropriate activities, and involving the child and caregiver in activities such as songs, dances, and games. However, visitor often fail to provide meaningful explanations and feedback to caregivers, and demonstrate a limited emphasis on language development. Many times required materials are often missing, the child is not challenged, and there is little constructive feedback and coaching provided to the caregiver.

The ultimate goal of this exercise has been to provide a pilot in order to I inform early childhood development policy in the LAC region. Future research could expand upon this study by (a) incorporating larger, more representative sample of home visits in each program, (b) analyzing these data in relation to program effects on early childhood development and parenting outcomes and (c) comparing results of different observational instruments, especially those that demonstrate predictive validity. 


\section{References}

Araujo, M. C., F. López Boo, and J. M. Puyana. 2013. Overview of Early Childhood Development Services in Latin America and the Caribbean. Washington, DC: Inter-American Development Bank.

Attanasio, Orazio P., Camila Fernández, Emla O. A. Fitzsimons, Sally M. Grantham-McGregor, Costas Meghir, and Marta Rubio-Codina. 2014. "Using the Infrastructure of a Conditional Cash Transfer Program to Deliver a Scalable Integrated Early Child Development Program in Colombia: Cluster Randomized Controlled Trial." BMJ 349 (September): g5785. doi:10.1136/bmj.g5785.

Berlinski, Samuel, and Norbert Schady, eds. 2015. The Early Years. New York: Palgrave Macmillan US. http://link.springer.com/10.1057/9781137536495.

Duggan, Anne, Amy Windham, Elizabeth McFarlane, Loretta Fuddy, Charles Rohde, Sharon Buchbinder, and Calvin Sia. 2000. "Hawaii's Healthy Start Program of Home Visiting for at-Risk Families: Evaluation of Family Identification, Family Engagement, and Service Delivery." Pediatrics 105 (Supplement 2): 250-59.

Engle, P. L., M. M. Black, J. R. Behrman, M. Cabral de Mello, P. J. Gertler, L. Kapiriri, R. Martorell, M. E. Young, and the International Child Development Steering Group. 2007. "Strategies to Avoid the Loss of Developmental Potential in More than 200 Million Children in the Developing World." Lancet 369(9557) January: 229-42.

Gertler, Paul, James Heckman, Rodrigo Pinto, Arianna Zanolini, Christel Vermeersch, Susan Walker, Susan M. Chang, and Sally Grantham-McGregor. 2014. "Labor Market Returns to an Early Childhood Stimulation Intervention in Jamaica." Science 344 (6187): 998-1001. doi:10.1126/science.1251178.

Grantham-McGregor, Sally, Yin Bun Cheung, Santiago Cueto, Paul Glewwe, Linda Richter, Barbara Strupp, International Child Development Steering Group, and others. 2007. "Developmental Potential in the First 5 Years for Children in Developing Countries." The Lancet 369 (9555): 60-70.

Grantham-McGregor, S. M, C. A Powell, S. P Walker, and J. H Himes. 1991. "Nutritional Supplementation, Psychosocial Stimulation, and Mental Development of Stunted Children: The Jamaican Study." The Lancet 338 (8758): 1-5. doi:10.1016/0140-6736(91)90001-6.

Ingoldsby, Erin M., Pilar Baca, Maureen W. McClatchey, Dennis W. Luckey, Mildred O. Ramsey, Joan M. Loch, Jan Lewis, et al. 2013. "Quasi-Experimental Pilot Study of Intervention to Increase Participant Retention and Completed Home Visits in the Nurse-Family Partnership." Prevention Science 14 (6): 525-34. doi:10.1007/s11121-013-0410-x. 
Kitzman, Harriet J. 2004. "Effective Early Childhood Development Programs for Low-Income Families: Home Visiting Interventions during Pregnancy and Early Childhood." Tremblay RE, Barr RG, Peters RDeV, Eds. Encyclopedia on Early Childhood Development, 1-7.

Kitzman, Harriet J., David L. Olds, C. Henderson, C. Hanks, R. Cole, R. Tatelbaum, K. McConnochie, et al. 1997. "Effect of Prenatal and Infancy Home Visitation by Nurses on Pregnancy Oucomes, Childhood Injuries, and Repeated Childbearing: A Randomized Controlled Trial." JAMA 278 (8): 644-52.

Kitzman HJ, Olds DL, Cole RE, and et al. 2010. "Enduring Effects of Prenatal and Infancy Home Visiting by Nurses on Children: Follow-up of a Randomized Trial among Children at Age 12 Years." Archives of Pediatrics \& Adolescent Medicine 164 (5): 412-18. doi:10.1001/archpediatrics.2010.76.

Love, John M., Ellen Eliason Kisker, Christine M. Ross, Peter Z. Schochet, Jeanne Brooks-Gunn, Diane Paulsell, Kimberly Boller, et al. 2002. "Making a Difference in the Lives of Infants and Toddlers and Their Families: The Impacts of Early Head Start. Volumes I-III: Final Technical Report [and] Appendixes [and] Local Contributions to Understanding the Programs and Their Impacts." http://eric.ed.gov/?id=ED472186.

Miller, W. R. \& Rollnick, S. (2002). Motivational Interviewing: preparing people for change (2nd ed.). New York: Guilford Press.

O'Brien, R. A., Moritz, P., Luckey, D. W., McClatchey, M. W., Ingoldsby, E. M., \& Olds, D. L. (2012). Mixed methods analysis of participant attrition in the nurse-family partnership. Prevention Science, 13(3), 219-228.

Olds, David L. 2006. "The Nurse-family Partnership: An Evidence-Based Preventive Intervention." Infant Mental Health Journal 27 (1): 5-25. doi:10.1002/imhj.20077.

Olds, David L., Charles R. Henderson, and Harriet Kitzman. 1994. "Does Prenatal and Infancy Nurse Home Visitation Have Enduring Effects on Qualities of Parental Caregiving and Child Health at 25 to 50 Months of Life?" Pediatrics 93 (1): 89-98.

Olds, David L., Charles R. Henderson, Robert Tatelbaum, and Robert Chamberlin. 1986. "Improving the Delivery of Prenatal Care and Outcomes of Pregnancy: A Randomized Trial of Nurse Home Visitation." Pediatrics 77 (1): 16-28.

Paulsell, D., Avellar, S., Martin, E. S., \& Del Grosso, P. (2010). Home visiting evidence of effectiveness review: Executive summary. Mathematica Policy Research

Peterson, Carla A., Gayle J. Luze, Elaine M. Eshbaugh, Hyun-Joo Jeon, and Kelly Ross Kantz. 2007. "Enhancing Parent-Child Interactions through Home Visiting: Promising Practice or Unfulfilled Promise?" Journal of Early Intervention 29 (2): 119-40. 
Riley, Shireen, Anne E. Brady, Jessica Goldberg, Francine Jacobs, and M. Ann Easterbrooks. 2008. "Once the Door Closes: Understanding the Parent-provider Relationship." Children and Youth Services Review 30 (5): 597-612. doi:10.1016/j.childyouth.2007.11.011.

Rosero, José, and Hessel Oosterbeek. 2011. "Trade-Offs between Different Early Childhood Interventions: Evidence from Ecuador." Tinbergen Institute Discussion Paper. http://www.econstor.eu/handle/10419/87225.

Sanders, M. (2008). Triple P-Positive Parenting Program as a public health approach to strengthening parenting. Journal of Family Psychology 22(4): 506-517. doi: 10.1037/08933200.22.3.506

Schodt, S. Parr, J. Araujo, C. Rubio-Codina, M. (2015) Measuring the Quality of Home-Visiting Services A Review of the Literature IDB Technical Note IDB-TN-881

Stoltzfus, E., \& Lynch, K. (2009). Home visitation for families with young children. R40705). Washington, DC: Congressional Research Service.

Vogel, Cheri A., Pia Caronongan, Jaime Thomas, Eileen Bandel, Yange Xue, Juliette Henke, Nikki Aikens, Kimberly Boller, and Lauren Murphy. 2015. "Toddlers in Early Head Start: A Portrait of 2-Year-Olds, Their Families, and the Programs Serving Them. Volume 1: Age 2 Report. OPRE Report 2015-10." Administration for Children \& Families. http://eric.ed.gov/?id=ED558558.

Walker, Susan P., Susan M. Chang, Marcos Vera-Hernández, and Sally Grantham-McGregor. 2011. "Early Childhood Stimulation Benefits Adult Competence and Reduces Violent Behavior." Pediatrics 127 (5): 849-57. doi:10.1542/peds.2010-2231.

Schady, N. Behrman, J., Araujo, M., Azuero, R. Bernal, R., Bravo, D., Lopez-Boo, F., Macours, K., Marshall, D., Paxson, C., \& Vakis, R. (2014). "Wealth Gradients in Early Childhood Cognitive Development in Five Latin American Countries" J. Human Resources Spring 2015 vol. 50 no. $2446-463$

Shankoff, J. (2010). Building a New Biodevelopmental Framework to Guide the Future of Early Childhood Policy. Child Development 81(1): 357-367.

Walker, S. P., S. M. Chang, M. Vera-Hernández, and S. Grantham-McGregor. 2011. "Early Childhood Stimulation Benefits Adult Competence and Reduces Violent Behavior." Pediatrics 127(5) May: 849-57. 


\section{Appendix 1: Instruments}

The following are the instruments used in this study:

- Child Development Home Visit Checklist - English

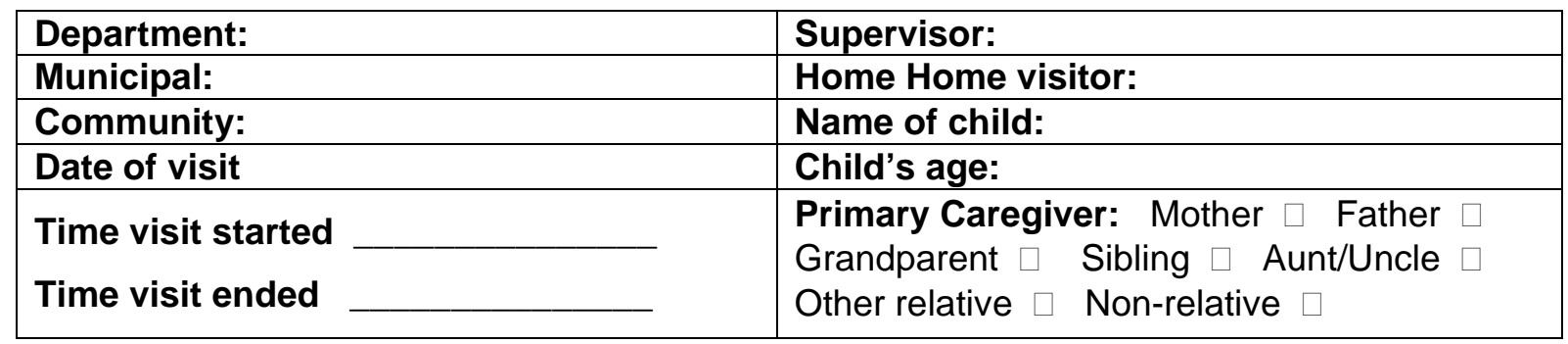

\section{Description of the Visit}

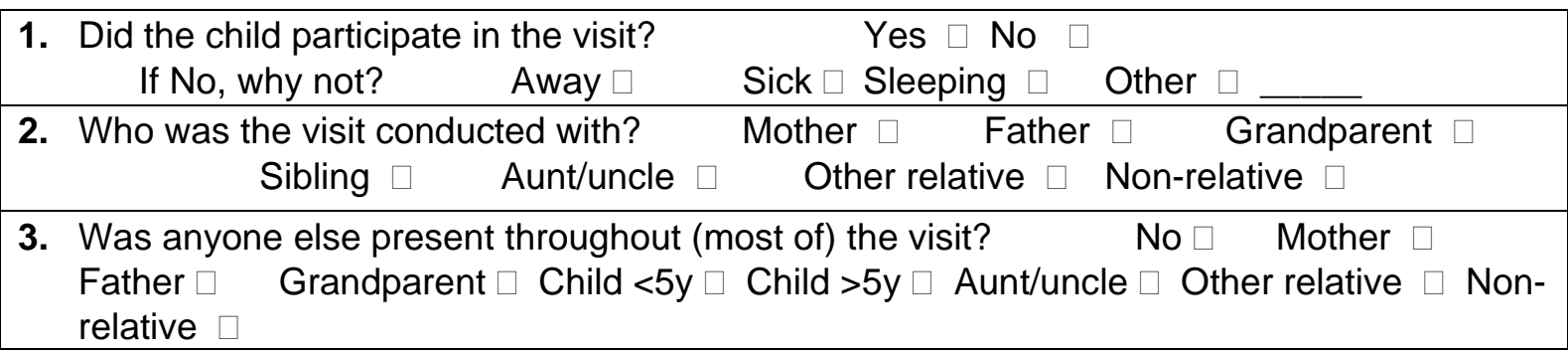

\section{Review of Last Visit}

\begin{tabular}{|l|l|l|l|l|l|l|}
\hline 4. $\begin{array}{l}\text { Home visitor checked with } \\
\text { caregiver about play sessions } \\
\text { between visits (content, } \\
\text { frequency, enjoyment) }\end{array}$ & Well Adequately & A little & $\begin{array}{l}\text { Did not } \\
\text { check }\end{array}$ & N/A \\
\hline $\begin{array}{l}\text { 5. Home visitor asked the } \\
\text { caregiver to demonstrate with } \\
\text { the child what had been done } \\
\text { since the last visit }\end{array}$ & $\begin{array}{l}\text { Caregiver } \\
\text { demonstrated } \\
\text { or explained } \\
\text { most of } \\
\text { activities of }\end{array}$ & $\begin{array}{l}\text { Some of } \\
\text { activities }\end{array}$ & $\begin{array}{l}\text { Little of } \\
\text { the } \\
\text { activities }\end{array}$ & $\begin{array}{l}\text { Home } \\
\text { visitor did } \\
\text { not ask }\end{array}$ & N/A \\
\hline
\end{tabular}


Activities and methods

\begin{tabular}{|c|c|c|c|c|c|}
\hline $\begin{array}{l}\text { 6. Home visitor brought the cartilla } \\
\text { de Programa to the visit? }\end{array}$ & Yes & No & $\begin{array}{l}\text { No, but the } \\
\text { caregiver }\end{array}$ & \multicolumn{2}{|c|}{ N/A } \\
\hline $\begin{array}{l}\text { 7. Home visitor used cartilla de } \\
\text { Programa Amor appropriately } \\
\text { during the visit }\end{array}$ & $\begin{array}{c}\text { Yes, } \\
\text { appropriate }\end{array}$ & Adequately & Inappropriate & $\begin{array}{l}\text { Did } \\
\text { not } \\
\text { use }\end{array}$ & $\mathrm{N} / \mathrm{A}$ \\
\hline $\begin{array}{l}\text { 8. Home visitor had prepared for the } \\
\text { visit in advance }\end{array}$ & Good & Adequately & A little & \multicolumn{2}{|c|}{ Not at all } \\
\hline $\begin{array}{l}\text { 9. Home visitor used age- } \\
\text { appropriate materials and } \\
\text { activities }\end{array}$ & Most correct & Some correct & Few correct & \multicolumn{2}{|c|}{$\begin{array}{l}\text { None } \\
\text { correct }\end{array}$} \\
\hline $\begin{array}{l}\text { 10. Home visitor put special emphasis } \\
\text { on language development }\end{array}$ & $\begin{array}{l}\text { Yes, strong } \\
\text { emphasis }\end{array}$ & Adequately & A little & \multicolumn{2}{|c|}{ None } \\
\hline $\begin{array}{l}\text { 11. Home visitor explained the } \\
\text { activities and objectives (what the } \\
\text { child should achieve) to the } \\
\text { caregiver }\end{array}$ & Good & Adequately & A little & \multicolumn{2}{|c|}{$\begin{array}{l}\text { Didn't } \\
\text { explain }\end{array}$} \\
\hline $\begin{array}{l}\text { 12. Home visitor demonstrated the } \\
\text { activities to the caregiver }\end{array}$ & Good & Adequately & A little & \multicolumn{2}{|c|}{$\begin{array}{c}\text { Didn't } \\
\text { demonstra } \\
\text { te }\end{array}$} \\
\hline $\begin{array}{l}\text { 13. Home visitor demonstrated the } \\
\text { activities to the child }\end{array}$ & Good & Adequately & A little & \multicolumn{2}{|c|}{$\begin{array}{c}\text { Didn't } \\
\text { demonstra } \\
\text { te }\end{array}$} \\
\hline $\begin{array}{l}\text { 14. Home visitor explained the } \\
\text { activities to the child }\end{array}$ & Good & Adequately & A little & \multicolumn{2}{|c|}{$\begin{array}{l}\text { Didn't } \\
\text { explain }\end{array}$} \\
\hline $\begin{array}{l}\text { 15. Home visitor asked the caregiver } \\
\text { to do the activities alone with the } \\
\text { child }\end{array}$ & $\begin{array}{l}\text { Most of the } \\
\text { time }\end{array}$ & $\begin{array}{l}\text { Some of the } \\
\text { time }\end{array}$ & None & \multicolumn{2}{|c|}{ Didn't ask } \\
\hline $\begin{array}{l}\text { 16. Home visitor got feedback from } \\
\text { the caregiver on what she was } \\
\text { going to do in the next week }\end{array}$ & $\begin{array}{l}\text { Most topics } \\
\text { remembered }\end{array}$ & $\begin{array}{l}\text { Some topics } \\
\text { remembered }\end{array}$ & $\begin{array}{l}\text { Few topics } \\
\text { remembered }\end{array}$ & \multicolumn{2}{|c|}{ Didn't ask } \\
\hline $\begin{array}{l}\text { 17. Home visitor spent time } \\
\text { discussing topics unrelated to the } \\
\text { objectives of the visit with } \\
\text { caregiver and other persons }\end{array}$ & $\begin{array}{l}\text { None of the } \\
\text { time }\end{array}$ & $\begin{array}{l}\text { Very little } \\
\text { time }\end{array}$ & $\begin{array}{l}\text { Some of the } \\
\text { time }\end{array}$ & \multicolumn{2}{|c|}{$\begin{array}{l}\text { Too much } \\
\text { of the time }\end{array}$} \\
\hline
\end{tabular}


Relationship between home visitor and caregiver

\begin{tabular}{|l|c|c|c|c|}
\hline 18. Home visitor listened to the caregiver & $\begin{array}{c}\text { Most of the } \\
\text { time }\end{array}$ & $\begin{array}{c}\text { Some of } \\
\text { the time }\end{array}$ & $\begin{array}{c}\text { Little of } \\
\text { the time }\end{array}$ & None \\
\hline $\begin{array}{l}\text { 19. Home visitor was responsive to the } \\
\text { caregiver }\end{array}$ & $\begin{array}{c}\text { Most of the } \\
\text { time }\end{array}$ & $\begin{array}{c}\text { Some of } \\
\text { the time }\end{array}$ & $\begin{array}{c}\text { Little of } \\
\text { the time }\end{array}$ & None \\
\hline 20. Home visitor asked the caregiver's opinion & $\begin{array}{c}\text { Most of the } \\
\text { time }\end{array}$ & $\begin{array}{c}\text { Some of } \\
\text { the time }\end{array}$ & $\begin{array}{c}\text { Little of } \\
\text { the time }\end{array}$ & None \\
\hline $\begin{array}{l}\text { 21. Home visitor encouraged and positively } \\
\text { reinforced the caregiver }\end{array}$ & $\begin{array}{c}\text { Most of the } \\
\text { time }\end{array}$ & $\begin{array}{c}\text { Some of } \\
\text { the time }\end{array}$ & $\begin{array}{c}\text { Little of } \\
\text { the time }\end{array}$ & None \\
\hline $\begin{array}{l}\text { 22. Overall, the relationship between the } \\
\text { home visitor and caregiver was warm, } \\
\text { understanding and cooperative. }\end{array}$ & $\begin{array}{c}\text { Most of the } \\
\text { time }\end{array}$ & $\begin{array}{c}\text { Some of } \\
\text { the time }\end{array}$ & $\begin{array}{c}\text { Little of } \\
\text { the time }\end{array}$ & None \\
\hline
\end{tabular}

Relationship between home visitor and child

\begin{tabular}{|c|c|c|c|c|}
\hline $\begin{array}{l}\text { 23. Home visitor listened to the child and } \\
\text { his/her } \\
\text { responded } \\
\text { vocalizations/gestures }\end{array}$ & $\begin{array}{c}\text { Most of the } \\
\text { time }\end{array}$ & $\begin{array}{c}\text { Some of } \\
\text { the time }\end{array}$ & $\begin{array}{c}\text { Little of } \\
\text { the time }\end{array}$ & None \\
\hline $\begin{array}{c}\text { 24. Home visitor praised the child when } \\
\text { he/she attempted/completed an activity }\end{array}$ & $\begin{array}{c}\text { Most of the } \\
\text { time }\end{array}$ & $\begin{array}{l}\text { Some of } \\
\text { the time }\end{array}$ & $\begin{array}{c}\text { Little of } \\
\text { the time }\end{array}$ & None \\
\hline $\begin{array}{l}\text { 25. Home visitor talked about activities that } \\
\text { child was doing }\end{array}$ & $\begin{array}{c}\text { Most of the } \\
\text { time }\end{array}$ & $\begin{array}{l}\text { Some of } \\
\text { the time }\end{array}$ & $\begin{array}{c}\text { Little of } \\
\text { the time }\end{array}$ & None \\
\hline $\begin{array}{c}\text { 26. Home visitor gave child enough time to } \\
\text { explore the materials and to complete the } \\
\text { activities }\end{array}$ & $\begin{array}{c}\text { Most of the } \\
\text { time }\end{array}$ & $\begin{array}{l}\text { Some of } \\
\text { the time }\end{array}$ & $\begin{array}{c}\text { Little of } \\
\text { the time }\end{array}$ & None \\
\hline $\begin{array}{c}\text { 27. Overall, the relationship between the } \\
\text { home visitor and the child was warm, } \\
\text { understanding and cooperative. }\end{array}$ & $\begin{array}{c}\text { Most of the } \\
\text { time }\end{array}$ & $\begin{array}{l}\text { Some of } \\
\text { the time }\end{array}$ & Little of \\
the time & None \\
\hline
\end{tabular}




\section{Overall visit: Participation}

\begin{tabular}{|c|c|c|c|c|}
\hline 28. Child actively participated in the visit & $\begin{array}{l}\text { Most of the } \\
\text { time }\end{array}$ & $\begin{array}{l}\text { Some of } \\
\text { the time }\end{array}$ & $\begin{array}{l}\text { Little of the } \\
\text { time }\end{array}$ & None \\
\hline $\begin{array}{l}\text { 29. Caregiver actively participated in the } \\
\text { visit }\end{array}$ & $\begin{array}{l}\text { Most of the } \\
\text { time }\end{array}$ & $\begin{array}{l}\text { Some of } \\
\text { the time }\end{array}$ & $\begin{array}{l}\text { Little of the } \\
\text { time }\end{array}$ & None \\
\hline $\begin{array}{l}\text { 30. The home visitor's overall effort to } \\
\text { encourage participation }\end{array}$ & $\begin{array}{l}\text { Home visitor } \\
\text { did everything } \\
\text { she could to } \\
\text { encourage } \\
\text { equal } \\
\text { participation }\end{array}$ & $\begin{array}{c}\text { Home } \\
\text { visitor } \\
\text { made a } \\
\text { sufficient } \\
\text { effort to } \\
\text { promote } \\
\text { participati } \\
\text { on in } \\
\text { most } \\
\text { parts of } \\
\text { the visit }\end{array}$ & $\begin{array}{l}\text { Home visitor } \\
\text { made an } \\
\text { insufficient } \\
\text { effort to } \\
\text { promote } \\
\text { participation }\end{array}$ & $\begin{array}{c}\text { Home } \\
\text { visitor } \\
\text { maintaine } \\
d \text { a } \\
\text { dominatin } \\
\text { g/ } \\
\text { authoritat } \\
\text { ive } \\
\text { attitude } \\
\text { througho } \\
\text { ut the } \\
\text { visit }\end{array}$ \\
\hline $\begin{array}{l}\text { 31. The overall atmosphere of the visit } \\
\text { was }\end{array}$ & Very happy & Happy & Neutral & $\begin{array}{c}\text { Unhappy, } \\
\text { uncomfor } \\
\text { table }\end{array}$ \\
\hline
\end{tabular}


- Child Development Home Visit Checklist - Spanish

Información básica

\begin{tabular}{|l|l|}
\hline Departamento & Supervisor \\
\hline Municipio & Educador \\
\hline Comunidad & Niño \\
\hline Fecha & Edad del niño \\
\hline Inicio de la visita (hora) & $\begin{array}{l}\text { Cuidador principal } \\
\text { Finalización de la vista (hora) } \_\end{array} \quad \begin{array}{l}\text { Madre } \square \text { Padre } \square \text { Abuelo/a } \square \quad \text { Hermano/a } \\
\text { Tíola } \square \text { Otro pariente } \square \text { Otro } \square\end{array}$ \\
\hline
\end{tabular}

Descripción de la visita

1. ¿Participó el niño en la visita? Sí $\square \quad$ No

Si No, ¿por qué? No estaba presente $\square \quad$ Estaba enfermo $\square \quad$ Estaba durmiendo Otro

2. ¿Con quién se hizo la visita?

Madre $\square$ Padre $\square \quad$ Abuelo/a $\square \quad$ Hermano/a $\square \quad$ Tío/a $\square \quad$ Otro pariente

Otro

3. ¿Estuvo presente alguien más durante la mayor parte de la visita?? No

Madre $\square \quad$ Padre $\square \quad$ Abuelo/a $\square$ Hermano/a $\square \quad$ Tío/a
Otro pariente $\square \quad$ Otro $\square$

\section{Revisión de la visita anterior}

\begin{tabular}{|c|c|c|c|c|c|c|}
\hline & $\begin{array}{l}\text { ¿La educadora preguntó a la } \\
\text { cuidadora acerca de las } \\
\text { actividades aprendidas durante } \\
\text { la visita anterior (contenido, } \\
\text { frecuencia, percepción)? }\end{array}$ & $\begin{array}{c}\text { Si, de } \\
\text { manera } \\
\text { buena }\end{array}$ & $\begin{array}{l}\text { Si, } \\
\text { preguntó } \\
\text { lo } \\
\text { suficiente }\end{array}$ & $\begin{array}{l}\text { Sí, un } \\
\text { poco }\end{array}$ & $\begin{array}{c}\text { No se lo } \\
\text { pregunt } \\
\text { ó }\end{array}$ & $\mathrm{n} / \mathrm{a}$ \\
\hline & $\begin{array}{l}\text { ¿Dio la oportunidad de que el } \\
\text { niño y la cuidadora mostraran lo } \\
\text { que el niño había aprendido } \\
\text { durante la visita pasada? }\end{array}$ & $\begin{array}{l}\text { Sí, mostró la } \\
\text { mayoría de } \\
\text { las } \\
\text { actividades }\end{array}$ & $\begin{array}{l}\text { Sí, mostró } \\
\text { algunas de } \\
\text { las } \\
\text { actividade } \\
\text { s }\end{array}$ & $\begin{array}{l}\text { Sí, pero } \\
\text { solo } \\
\text { mostró } \\
\text { algunas } \\
\text { actividade } \\
\text { s }\end{array}$ & $\begin{array}{l}\text { No se lo } \\
\text { pregunt } \\
\text { ó }\end{array}$ & $\mathrm{n} / \mathrm{a}$ \\
\hline
\end{tabular}


Actividades y metodología

\begin{tabular}{|c|c|c|c|c|}
\hline $\begin{array}{l}\text { 6. ¿Llevó la educadora la cartilla del } \\
\text { programa? }\end{array}$ & Sí & No & $\begin{array}{l}\text { No, pero la } \\
\text { cuidadora la } \\
\text { tenía }\end{array}$ & $\mathrm{n} / \mathrm{a}$ \\
\hline $\begin{array}{l}\text { 7. ¿La educadora utilizó la cartilla } \\
\text { durante la visita? }\end{array}$ & $\begin{array}{c}\text { Sí, de } \\
\text { manera muy } \\
\text { adecuada }\end{array}$ & $\begin{array}{c}\text { Sí, de } \\
\text { manera } \\
\text { suficiente } \\
\end{array}$ & $\begin{array}{c}\text { Sí, de } \\
\text { manera no } \\
\text { adecuada } \\
\end{array}$ & No la utilizó \\
\hline $\begin{array}{l}\text { 8. ¿Qué tanto cree que la educadora } \\
\text { había preparado para la visita? }\end{array}$ & $\begin{array}{l}\text { Bastante } \\
\text { (mucho) }\end{array}$ & $\begin{array}{l}\text { Lo } \\
\text { suficiente }\end{array}$ & Un poco & Nada \\
\hline $\begin{array}{l}\text { 9. ¿La educadora utilizó materiales } \\
\text { adecuados según la edad del niño } \\
\text { durante la visita? }\end{array}$ & $\begin{array}{l}\text { Todos } \\
\text { adecuados }\end{array}$ & $\begin{array}{l}\text { Algunos } \\
\text { adecuados }\end{array}$ & $\begin{array}{l}\text { Muy pocos } \\
\text { adecuados }\end{array}$ & $\begin{array}{l}\text { Ningún } \\
\text { material } \\
\text { adecuado }\end{array}$ \\
\hline $\begin{array}{l}\text { 10. ¿La educadora hizo algún énfasis } \\
\text { en el desarrollo del lenguaje? }\end{array}$ & $\begin{array}{l}\text { Bastante } \\
\text { (mucho) }\end{array}$ & $\begin{array}{c}\text { Lo } \\
\text { suficiente }\end{array}$ & Un poco & Nada \\
\hline $\begin{array}{l}\text { 11. La manera como la educadora } \\
\text { explicó el objetivo de las } \\
\text { actividades (lo que el niño debe } \\
\text { lograr) fue: }\end{array}$ & Buena & Regular & Insuficiente & $\begin{array}{l}\text { No explicó } \\
\text { el objetivo }\end{array}$ \\
\hline $\begin{array}{l}\text { 12. La manera como la educadora } \\
\text { modeló las actividades para la } \\
\text { cuidadora fue: }\end{array}$ & Buena & Regular & Insuficiente & $\begin{array}{l}\text { No las } \\
\text { modeló }\end{array}$ \\
\hline $\begin{array}{l}\text { 13. La manera como la educadora } \\
\text { modeló las actividades para el } \\
\text { niño fue: }\end{array}$ & Buena & Regular & Insuficiente & $\begin{array}{l}\text { No las } \\
\text { modeló }\end{array}$ \\
\hline $\begin{array}{l}\text { 14. La manera como la educadora } \\
\text { explicó las actividades al niño fue: }\end{array}$ & Buena & Regular & Insuficiente & $\begin{array}{l}\text { No se las } \\
\text { explicó }\end{array}$ \\
\hline $\begin{array}{l}\text { 15. ¿La educadora dejó que la } \\
\text { cuidadora hiciera la actividad sola } \\
\text { con el niño? }\end{array}$ & $\begin{array}{l}\text { Sí, para la } \\
\text { mayoría de } \\
\text { las } \\
\text { actividades }\end{array}$ & $\begin{array}{l}\text { Sí, para } \\
\text { algunas de } \\
\text { las } \\
\text { actividades }\end{array}$ & $\begin{array}{c}\text { Sí, para } \\
\text { pocas } \\
\text { actividades }\end{array}$ & $\begin{array}{l}\text { No, para } \\
\text { ninguna } \\
\text { actividad }\end{array}$ \\
\hline $\begin{array}{l}\text { 16. ¿La educadora y la cuidadora } \\
\text { hablaron de las actividades que la } \\
\text { cuidadora haría durante la } \\
\text { semana con el niño? }\end{array}$ & $\begin{array}{c}\text { Sí, hablaron } \\
\text { de la } \\
\text { mayoría de } \\
\text { las } \\
\text { actividades/ } \\
\text { temas }\end{array}$ & $\begin{array}{l}\text { Sí, hablaron } \\
\text { de algunas } \\
\text { actividades/ } \\
\text { temas }\end{array}$ & $\begin{array}{l}\text { Hablaron de } \\
\text { muy pocas } \\
\text { de las } \\
\text { actividades } \\
\text { /temas }\end{array}$ & $\begin{array}{l}\text { No se lo } \\
\text { preguntó }\end{array}$ \\
\hline $\begin{array}{l}\text { 17. ¿La educadora habló sobre temas } \\
\text { no relacionados a los objetivos de } \\
\text { la visita con la cuidadora u otros } \\
\text { miembros del hogar? }\end{array}$ & No, nunca & Muy poco & $\begin{array}{l}\text { Sí, en } \\
\text { algunos } \\
\text { momentos }\end{array}$ & $\begin{array}{l}\text { Sí, mucho } \\
\text { (demasiad) }\end{array}$ \\
\hline
\end{tabular}


Relación entre la educadora y la cuidadora

\begin{tabular}{|l|c|c|c|c|}
\hline 18. ¿La educadora escuchó a la cuidadora? & $\begin{array}{c}\text { Sí, la mayor } \\
\text { parte del } \\
\text { tiempo }\end{array}$ & $\begin{array}{c}\text { Sí, parte } \\
\text { del } \\
\text { tiempo }\end{array}$ & $\begin{array}{c}\text { Casi } \\
\text { nunca }\end{array}$ & Nunca \\
\hline $\begin{array}{l}\text { 19. ¿La educadora respondió oportunamente a } \\
\text { la cuidadora? }\end{array}$ & $\begin{array}{c}\text { Sí, la mayor } \\
\text { parte del } \\
\text { tiempo }\end{array}$ & $\begin{array}{c}\text { Sí, parte } \\
\text { del } \\
\text { tiempo }\end{array}$ & $\begin{array}{c}\text { Casi } \\
\text { nunca }\end{array}$ & Nunca \\
\hline $\begin{array}{l}\text { 20. ¿La educadora preguntó a la cuidadora su } \\
\text { opinión? }\end{array}$ & $\begin{array}{c}\text { Sí, la mayor } \\
\text { parte del } \\
\text { tiempo }\end{array}$ & $\begin{array}{c}\text { Sí, parte } \\
\text { del } \\
\text { tiempo }\end{array}$ & $\begin{array}{c}\text { Casi } \\
\text { nunca }\end{array}$ & Nunca \\
\hline $\begin{array}{l}\text { 21. ¿La educadora animó, motivó y dio } \\
\text { retroalimentación positiva a la cuidadora? }\end{array}$ & $\begin{array}{c}\text { Sí, la mayor } \\
\text { parte del } \\
\text { tiempo }\end{array}$ & $\begin{array}{c}\text { Sí, parte } \\
\text { del } \\
\text { tiempo }\end{array}$ & Casi & nunca \\
\hline $\begin{array}{l}\text { 22. ¿En general la relación entre la educadora } \\
\text { y la cuidadora fue de calidez, comprensión, } \\
\text { y cooperación? }\end{array}$ & $\begin{array}{c}\text { Sí, la mayor } \\
\text { parte del } \\
\text { tiempo }\end{array}$ & $\begin{array}{c}\text { Sí, parte } \\
\text { del } \\
\text { tiempo }\end{array}$ & $\begin{array}{c}\text { Casi } \\
\text { nunca }\end{array}$ & Nunca \\
\hline
\end{tabular}

\section{Relación entre la educadora y el niño}

\begin{tabular}{|l|c|c|c|c|}
\hline $\begin{array}{c}\text { 23. ¿La educadora prestó atención al niño, le } \\
\text { escuchó y respondió a sus vocalizaciones } \\
\text { (sonidos o palabritas), gestos e intentos de } \\
\text { comunicar? }\end{array}$ & $\begin{array}{c}\text { Sí, la mayor } \\
\text { parte del } \\
\text { tiempo }\end{array}$ & $\begin{array}{c}\text { Sí, parte } \\
\text { del } \\
\text { tiempo }\end{array}$ & $\begin{array}{c}\text { Casi } \\
\text { nunca }\end{array}$ & Nunca \\
\hline $\begin{array}{l}\text { 24. ¿La educadora felicitó al niño cada vez que } \\
\text { intentaba realizar una actividad o cuando } \\
\text { conseguía realizarla? }\end{array}$ & $\begin{array}{c}\text { Sí, la mayor } \\
\text { parte del } \\
\text { tiempo }\end{array}$ & $\begin{array}{c}\text { Sí, parte } \\
\text { del } \\
\text { tiempo }\end{array}$ & $\begin{array}{c}\text { Casi } \\
\text { nunca }\end{array}$ & Nunca \\
\hline $\begin{array}{l}\text { 25. ¿La educadora habló de las actividades que } \\
\text { el niño hacía? }\end{array}$ & $\begin{array}{c}\text { Sí, la mayor } \\
\text { parte del } \\
\text { tiempo }\end{array}$ & $\begin{array}{c}\text { Sí, parte } \\
\text { del } \\
\text { tiempo }\end{array}$ & $\begin{array}{c}\text { Casi } \\
\text { nunca }\end{array}$ & Nunca \\
\hline $\begin{array}{l}\text { 26. ¿La educadora procuró no apurarse y darle } \\
\text { al niño el tiempo necesario para intentar } \\
\text { realizar la actividad? }\end{array}$ & $\begin{array}{c}\text { Sí, la mayor } \\
\text { parte del } \\
\text { tiempo }\end{array}$ & $\begin{array}{c}\text { Sí, parte } \\
\text { del } \\
\text { tiempo }\end{array}$ & $\begin{array}{c}\text { Casi } \\
\text { nunca }\end{array}$ & Nunca \\
\hline $\begin{array}{l}\text { 27. ¿En general la relación entre la educadora y } \\
\text { el niño fue de calidez, comprensión, y } \\
\text { cooperación? }\end{array}$ & $\begin{array}{c}\text { Sí, la mayor } \\
\text { parte del } \\
\text { tiempo }\end{array}$ & $\begin{array}{c}\text { Sí, parte } \\
\text { del } \\
\text { tiempo }\end{array}$ & $\begin{array}{c}\text { Casi } \\
\text { nunca }\end{array}$ & Nunca \\
\hline
\end{tabular}




\section{Participación}

\begin{tabular}{|l|c|c|c|c|}
\hline $\begin{array}{l}\text { 28. ¿Participó el niño } \\
\text { activamente a lo largo de la } \\
\text { visita? }\end{array}$ & $\begin{array}{c}\text { Sí, la mayor } \\
\text { parte del } \\
\text { tiempo }\end{array}$ & $\begin{array}{c}\text { Sí, parte del } \\
\text { tiempo }\end{array}$ & Casi nunca & Nunca \\
\hline $\begin{array}{l}\text { 29. ¿Participó la cuidadora } \\
\text { activamente a lo largo de la } \\
\text { visita? }\end{array}$ & $\begin{array}{c}\text { Sí, la mayor } \\
\text { parte del } \\
\text { tiempo }\end{array}$ & $\begin{array}{c}\text { Sí, parte del } \\
\text { tiempo }\end{array}$ & Casi nunca & Nunca \\
\hline $\begin{array}{l}\text { 30. ¿Cómo calificaría la actitud } \\
\text { de la educadora durante la } \\
\text { visita? }\end{array}$ & $\begin{array}{c}\text { Hizo mucho } \\
\text { esfuerzo } \\
\text { para } \\
\text { provocar la } \\
\text { participación } \\
\text { y promovió } \\
\text { la confianza }\end{array}$ & $\begin{array}{c}\text { Hizo } \\
\text { esfuerzo } \\
\text { adecuado } \\
\text { para } \\
\text { provocar la } \\
\text { participación } \\
\text { yromovió la } \\
\text { confianza }\end{array}$ & $\begin{array}{c}\text { No promovió } \\
\text { suficiente la } \\
\text { participación } \\
\text { y confianza }\end{array}$ & $\begin{array}{c}\text { Actuaba de } \\
\text { manera muy } \\
\text { dominante }\end{array}$ \\
\hline $\begin{array}{l}\text { 31. El ambiente general de la } \\
\text { visita fue: }\end{array}$ & Muy feliz & $\begin{array}{c}\text { Felizl } \\
\text { cómodo }\end{array}$ & Neutral & Incomodo \\
\hline
\end{tabular}

- Nutrition Program Checklist

Información básica

\begin{tabular}{|l|l|}
\hline \multirow{2}{*}{ Departamento } & Mujer embarazada Sí $\square \quad$ No $\square$ \\
\cline { 2 - 2 } & Supervisor \\
\hline Municipio & Educador \\
\hline Comunidad & Niño \\
\hline Fecha & Edad del niño \\
\hline Inicio de la visita (hora) & Cuidador principal \\
Finalización de la vista (hora) & $\begin{array}{l}\text { Madre } \square \text { Padre } \square \text { Abuelo/a } \square \quad \text { Hermano/a } \\
\text { Tío/a } \square \text { Otro pariente } \square \text { Otro } \square\end{array}$ \\
\hline
\end{tabular}

\section{Descripción básica de la visita}

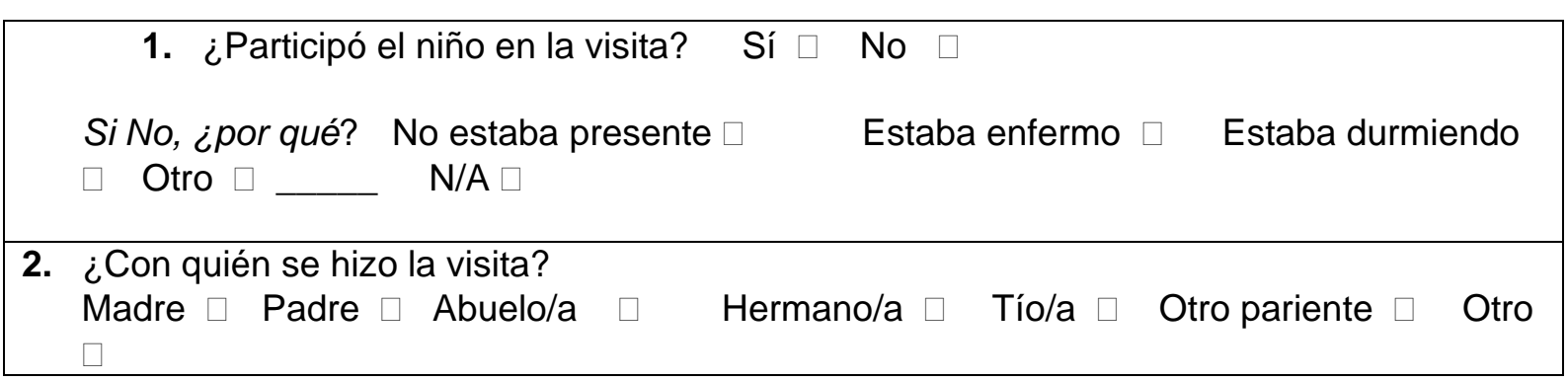




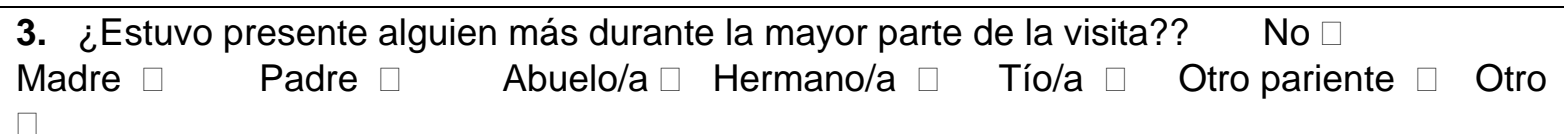

\section{Toma del peso}

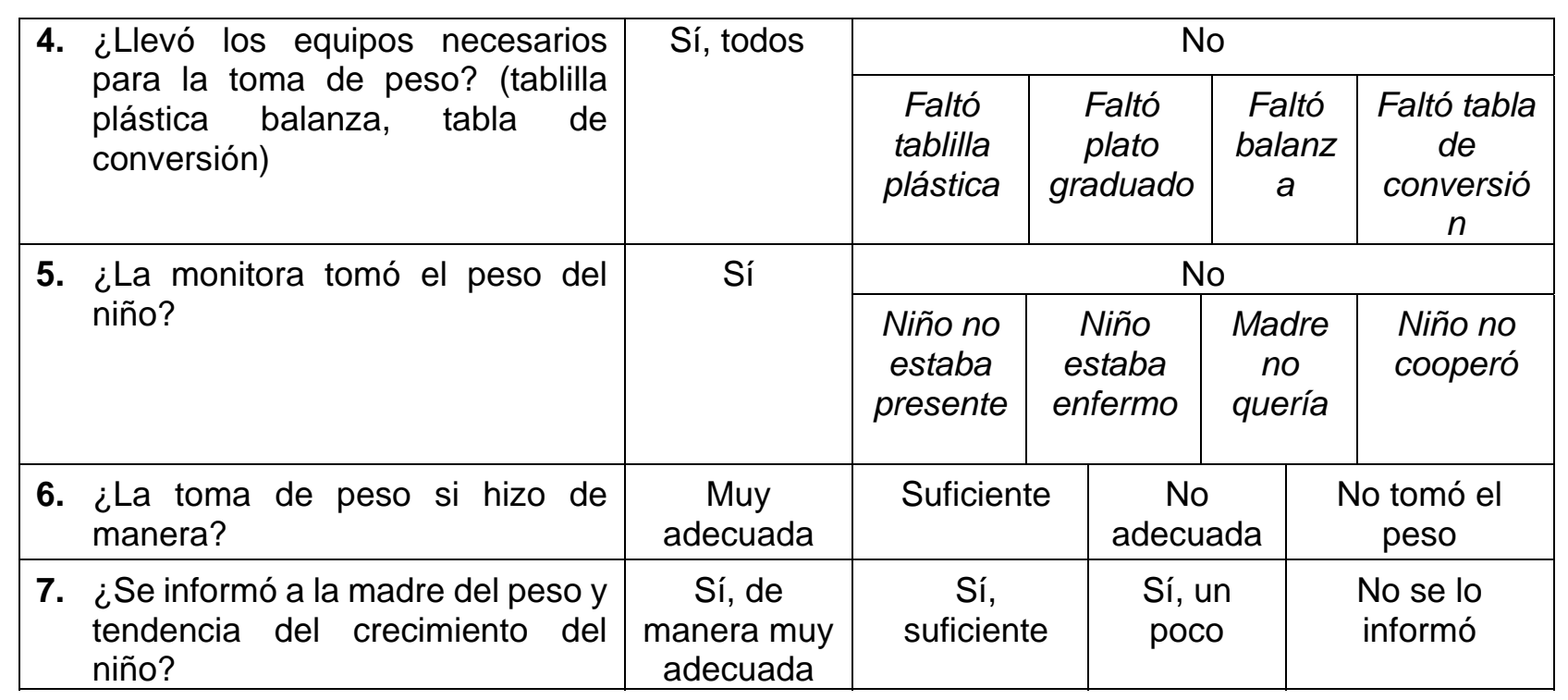

\section{Consejería individualizada}

\begin{tabular}{|l|c|c|c|c|c|}
\hline $\begin{array}{l}\text { 8. ¿La monitora preguntó a la madre } \\
\text { acerca de los temas conversados } \\
\text { durante la visita anterior? }\end{array}$ & $\begin{array}{c}\text { Si, de } \\
\text { manera } \\
\text { buena } \\
\text { lo suficiente }\end{array}$ & $\begin{array}{c}\text { Sí, un } \\
\text { poco }\end{array}$ & \multicolumn{2}{|c|}{$\begin{array}{c}\text { No se lo } \\
\text { preguntó }\end{array}$} \\
\hline $\begin{array}{l}\text { 9. ¿Llevó el manual /guía/láminas } \\
\text { del programa (materiales de } \\
\text { consejería individualizada y } \\
\text { registro de situación del niño) }\end{array}$ & Sí, todos & Algunos & Pocos & $\begin{array}{c}\text { Ningun } \\
\text { os }\end{array}$ & N/A \\
\hline $\begin{array}{l}\text { 10. ¿La monitora utilizó manual } \\
\text { lguía/láminas durante la visita? }\end{array}$ & $\begin{array}{c}\text { Sí, de } \\
\text { manera muy } \\
\text { adecuada }\end{array}$ & $\begin{array}{c}\text { Sí, de } \\
\text { manera } \\
\text { suficiente }\end{array}$ & $\begin{array}{c}\text { Sí, de } \\
\text { manera no } \\
\text { adecuada }\end{array}$ & \multicolumn{2}{|c|}{ No la utilizó } \\
\hline $\begin{array}{l}\text { 11. ¿Qué tanto cree que la monitora } \\
\text { había preparado para la visita? }\end{array}$ & $\begin{array}{c}\text { Bastante } \\
\text { (mucho) }\end{array}$ & $\begin{array}{c}\text { Lo } \\
\text { suficiente }\end{array}$ & Un poco & \multicolumn{2}{|c|}{ Nada } \\
\hline $\begin{array}{l}\text { 12. ¿La monitora le ofreció } \\
\text { motivaciones a la madre para } \\
\text { promover las prácticas de } \\
\text { alimentación adecuadas (según } \\
\text { edad del niño)? }\end{array}$ & Sí & Sí, algunas & Muy pocas & No \\
\hline $\begin{array}{l}\text { 13. ¿Los temas que la monitora } \\
\text { presentó fueron adecuados para } \\
\text { la edad del niño? }\end{array}$ & Sí & Sí, algunas & Muy pocas & \multicolumn{2}{|c|}{ No } \\
\hline
\end{tabular}




\begin{tabular}{|l|l|c|c|c|}
\hline $\begin{array}{l}\text { 14. ¿Cómo fueron los acuerdos que } \\
\text { se hicieron al respecto las } \\
\text { prácticas de alimentación y/o } \\
\text { cuidados de salud que la madre } \\
\text { haría durante el mes con el niño? }\end{array}$ & & Suficiente & Insuficiente & $\begin{array}{c}\text { No se lo } \\
\text { preguntó }\end{array}$ \\
\hline $\begin{array}{l}\text { 15. ¿La monitora habló sobre temas } \\
\text { no relacionados a los objetivos de } \\
\text { la visita con la madre u otros } \\
\text { miembros del hogar? }\end{array}$ & No, nunca & Muy poco & $\begin{array}{c}\text { Sí, en } \\
\text { algunos } \\
\text { momentos }\end{array}$ & $\begin{array}{c}\text { Sí, mucho } \\
\text { (demasiado) }\end{array}$ \\
\hline
\end{tabular}

Relación entre la monitora y la madre

\begin{tabular}{|c|c|c|c|c|}
\hline 16 ¿La monitora escuchó a la madre? & $\begin{array}{c}\text { Sí, la mayor } \\
\text { parte del } \\
\text { tiempo }\end{array}$ & $\begin{array}{c}\text { Sí, parte } \\
\text { del } \\
\text { tiempo }\end{array}$ & $\begin{array}{c}\text { Casi } \\
\text { nunca }\end{array}$ & Nunca \\
\hline $\begin{array}{l}\text { 17. ¿La monitora respondió oportunamente a la } \\
\text { madre? }\end{array}$ & $\begin{array}{l}\text { Sí, la mayor } \\
\text { parte del } \\
\text { tiempo }\end{array}$ & $\begin{array}{l}\text { Sí, parte } \\
\text { del } \\
\text { tiempo }\end{array}$ & $\begin{array}{c}\text { Casi } \\
\text { nunca }\end{array}$ & Nunca \\
\hline 18. ¿La monitora preguntó a la madre su opinión? & $\begin{array}{l}\text { Sí, la mayor } \\
\text { parte del } \\
\text { tiempo }\end{array}$ & $\begin{array}{l}\text { Sí, parte } \\
\text { del } \\
\text { tiempo }\end{array}$ & $\begin{array}{c}\text { Casi } \\
\text { nunca }\end{array}$ & Nunca \\
\hline $\begin{array}{l}\text { 19. ¿La monitora animó, motivó y dio } \\
\text { retroalimentación positiva a la madre? }\end{array}$ & $\begin{array}{l}\text { Sí, la mayor } \\
\text { parte del } \\
\text { tiempo }\end{array}$ & $\begin{array}{l}\text { Sí, parte } \\
\text { del } \\
\text { tiempo }\end{array}$ & $\begin{array}{c}\text { Casi } \\
\text { nunca }\end{array}$ & Nunca \\
\hline $\begin{array}{l}\text { 20. ¿En general la relación entre la monitora y la } \\
\text { madre fue de calidez, comprensión, y } \\
\text { cooperación? }\end{array}$ & $\begin{array}{l}\text { Sí, la mayor } \\
\text { parte del } \\
\text { tiempo }\end{array}$ & $\begin{array}{l}\text { Sí, parte } \\
\text { del } \\
\text { tiempo }\end{array}$ & $\begin{array}{c}\text { Casi } \\
\text { nunca }\end{array}$ & Nunca \\
\hline
\end{tabular}

\section{Participación}

\begin{tabular}{|l|c|c|c|c|}
\hline $\begin{array}{l}\text { 21. ¿Participó la madre } \\
\text { activamente a lo largo de la } \\
\text { visita? }\end{array}$ & $\begin{array}{c}\text { Sí, la mayor } \\
\text { parte del } \\
\text { tiempo }\end{array}$ & $\begin{array}{c}\text { Sí, parte del } \\
\text { tiempo }\end{array}$ & Casi nunca & Nunca \\
\hline $\begin{array}{c}\text { 22. ¿Cómo calificaría la actitud } \\
\text { de la monitora durante la } \\
\text { visita? }\end{array}$ & $\begin{array}{c}\text { Hizo mucho } \\
\text { esfuerzo para } \\
\text { provocar la } \\
\text { participación y } \\
\text { promovió la } \\
\text { confianza }\end{array}$ & $\begin{array}{c}\text { Hizo esfuerzo } \\
\text { adecuado } \\
\text { para provocar } \\
\text { la } \\
\text { participación } \\
\text { y promovió la } \\
\text { confianza }\end{array}$ & $\begin{array}{c}\text { No promovió } \\
\text { suficiente la } \\
\text { participación } \\
\text { y confianza }\end{array}$ & $\begin{array}{c}\text { Actuaba de } \\
\text { manera muy } \\
\text { dominante }\end{array}$ \\
\hline $\begin{array}{l}\text { 23. El ambiente general de la la } \\
\text { visita fue: }\end{array}$ & Muy feliz & Feliz/ cómodo & Neutral & Incomodo \\
\hline
\end{tabular}


- Basic Program Information Checklist

\begin{tabular}{|l|l|}
\hline Nombre del programa & \\
\hline Número de niños atendidos & \\
\hline Rango de edad niños atendidos & \\
\hline Frecuencias de las visitas & \\
\hline Duración de las visitas & \\
\hline $\begin{array}{l}\text { Perfil de educador/a (educación, } \\
\text { capacitación, remuneración) }\end{array}$ & \\
\hline $\begin{array}{l}\text { Número de familias/niños per } \\
\text { educador/a }\end{array}$ & \\
\hline $\begin{array}{l}\text { Currículo: ¿cómo se definen las } \\
\text { actividades a realizar? (¿Según } \\
\text { edad precisa? ¿Rangos de edad? } \\
\text { ¿Número de visita? ¿Educadoras } \\
\text { deben ajustar según capacidades } \\
\text { observadas del niño?) }\end{array}$ \\
\hline $\begin{array}{l}\text { Currículo/metodología: ¿se pone } \\
\text { énfasis en el desarrollo del } \\
\text { lenguaje? }\end{array}$ \\
\hline $\begin{array}{l}\text { Materiales y manuales: ¿hay algún } \\
\text { material/manual que la educadora } \\
\text { debe llevar a cada visita? }\end{array}$
\end{tabular}


IX. Appendix 2: Overview of Programs characteristics

A2.1 Coverage and cost

\begin{tabular}{|c|c|c|c|c|c|c|c|}
\hline Country & Brazil & Ecuador & Panama & Peru & Jamaica & Nicaragua & Bolivia \\
\hline Program & $\begin{array}{l}\text { Primera } \\
\text { Infancia } \\
\text { Melhor } \\
\text { (PIM) }\end{array}$ & $\begin{array}{c}\text { Creciendo } \\
\text { con nuestros } \\
\text { hijos } \\
\text { (CNH) }\end{array}$ & $\begin{array}{l}\text { Atención Integral } \\
\text { de la Niñez en la } \\
\text { Comunidad } \\
\text { (AIN-C) }\end{array}$ & Cuna Mas & $\begin{array}{l}\text { Home- } \\
\text { Visit } \\
\text { Program }\end{array}$ & $\begin{array}{c}\text { Programa de } \\
\text { Acompañamiento } \\
\text { a la Política de } \\
\text { Primera Infancia } \\
\text { (PAIPPI) }\end{array}$ & $\begin{array}{l}\text { Consejo de } \\
\text { Salud Rural } \\
\text { Andino - } \\
\text { Home Visit } \\
\text { Program } \\
\text { (CSRA) }\end{array}$ \\
\hline Focus & stimulation & stimulation & nutrition & stimulation & stimulation & stimulation & nutrition \\
\hline Coverage & 40,000 & 356,400 & N/A & 43,000 & N/A & 45,000 & 1,000 \\
\hline $\begin{array}{l}\text { Geographic } \\
\text { coverage }\end{array}$ & $\begin{array}{l}\text { Rio Grande } \\
\text { do Sul state }\end{array}$ & $\begin{array}{l}\text { Nationwide } \\
\text { Mainly rural }\end{array}$ & $\begin{array}{l}3 \text { Indigenous } \\
\text { Comarcas }\end{array}$ & $\begin{array}{l}\text { Nationwide } \\
\text { Mainly rural }\end{array}$ & N/A & $\begin{array}{c}\text { Nationwide (37 } \\
\text { urban and rural } \\
\text { municipalities) }\end{array}$ & $\begin{array}{c}\text { El Alto } \\
\text { municipality }\end{array}$ \\
\hline $\begin{array}{l}\text { Age group } \\
\text { served }\end{array}$ & $\begin{array}{c}\text { Prenatal-72 } \\
\text { mo. }\end{array}$ & 0-60 mo. & $0-24 \mathrm{mo}^{\wedge}$ & 0-36 mo. & 6-42 mo. & $\begin{array}{c}0-72 \text { mo. (focus } \\
\text { on } 0-36 \text { mo.) }\end{array}$ & Prenatal-24 mo. \\
\hline $\begin{array}{l}\text { Target } \\
\text { population ** }\end{array}$ & $\begin{array}{l}\text { Vulnerable } \\
\text { families }\end{array}$ & $\begin{array}{l}\text { Low-income } \\
\text { families at } \\
\text { risk }\end{array}$ & $\begin{array}{l}\text { Indigenous } \\
\text { population }\end{array}$ & $\begin{array}{l}\text { Low-income } \\
\text { families, } \\
\text { malnourished } \\
\text { children * }\end{array}$ & $\begin{array}{l}\text { Vulnerable } \\
\text { families }\end{array}$ & $\begin{array}{c}\text { Families in high } \\
\text { poverty } \\
\text { municipalities }\end{array}$ & $\begin{array}{l}\text { Vulnerable } \\
\text { families }\end{array}$ \\
\hline Targeting & Geographic & $\begin{array}{l}\text { Availability of } \\
\text { services in the } \\
\text { area. }\end{array}$ & Geographic & Geographic & & Poverty & \\
\hline Centers & N/A & $\begin{array}{l}907 \text { ad-hoc } \\
\text { centres }\end{array}$ & $\begin{array}{c}\text { Homes, } \\
\text { community } \\
\text { centers, health } \\
\text { centers }\end{array}$ & N/A & N/A & N/A & N/A \\
\hline $\begin{array}{l}\text { Annual cost / } \\
\text { child (US\$) }\end{array}$ & 181 & 302 & N/A & 300 & N/A & 110 & N/A \\
\hline
\end{tabular}

* Children living in districts with: i) poverty rates above $50 \%$; ii) chronic malnutriton above $30 \%$; iii) Juntos CCT operating; iv) more than $50 \%$ of population living in rural area

${ }^{* *}$ As reported by programs

$\wedge$ Health activities such as screening for diarrhea and pneumonia are extended to children 25-60 months 
A2.2 Program characteristics

\begin{tabular}{|c|c|c|c|c|c|c|c|}
\hline Country & Brazil & Ecuador & Panama & Peru & Jamaica & Nicaragua & Bolivia \\
\hline Program & $\begin{array}{c}\text { Primera Infancia } \\
\text { Melhor (PIM) }\end{array}$ & $\begin{array}{c}\text { Creciendo } \\
\text { con } \\
\text { nuestros } \\
\text { hijos }(\mathrm{CNH})\end{array}$ & $\begin{array}{c}\text { Atención } \\
\text { Integral de la } \\
\text { Niñez en la } \\
\text { Comunidad } \\
\text { (AIN-C) }\end{array}$ & Cuna Mas & $\begin{array}{l}\text { Home-Visit } \\
\text { Program }\end{array}$ & $\begin{array}{c}\text { Programa de } \\
\text { Acompañamiento } \\
\text { a la Política de } \\
\text { Primera Infancia } \\
\text { (PAIPPI) }\end{array}$ & $\begin{array}{l}\text { Consejo de } \\
\text { Salud Rural } \\
\text { Andino - } \\
\text { Home Visit } \\
\text { Program } \\
\text { (CSRA) } \\
\end{array}$ \\
\hline Delivery & home visits & $\begin{array}{l}\text { home visits } \\
\text { and groups } \\
\end{array}$ & \begin{tabular}{|c|} 
home visits and \\
groups
\end{tabular} & home visits & home visits & home visits & \\
\hline $\begin{array}{l}\text { Families per } \\
\text { visitor }\end{array}$ & 25 & 35 & 10 & 11 & $\begin{array}{l}\text { 16-20 families } \\
\text { in home visits }\end{array}$ & 25 & 90 \\
\hline $\begin{array}{l}\text { Operating } \\
\text { schedule } \\
\text { (months per } \\
\text { year) }\end{array}$ & 12 & 12 & 12 & 12 & 11 & 11 & 11 \\
\hline Frequency & Weekly & weekly & monthly & weekly & $\begin{array}{l}\text { weekly or } 1 \\
\text { visit/2 weeks }\end{array}$ & $\begin{array}{c}\text { Children } 0-3 \\
\text { years old: every } \\
15 \text { days Children } 4 \\
-6 \text { years: every } 2 \\
\text { months }\end{array}$ & $\begin{array}{l}\text { prenatal-12 } \\
\text { mo.: every } 15 \\
\text { days } 13-24 \\
\text { mo.: monthly } \\
\text { visits }\end{array}$ \\
\hline $\begin{array}{l}\text { Duration of } \\
\text { visit/session }\end{array}$ & 45 minutes & $\begin{array}{c}4 \text { hours } \\
\text { session } \\
1 \text { hour } \\
\text { home visit }\end{array}$ & $45-60 \min$ & 1 hour & $\begin{array}{l}30-45 \\
\text { minutes }\end{array}$ & 60 minutes & 30 minutes \\
\hline Content & $\begin{array}{l}\text { Activities that } \\
\text { encourage } \\
\text { caregiver to play } \\
\text { with the child and } \\
\text { build toys from } \\
\text { basic materials }\end{array}$ & $\begin{array}{l}\text { Support for } \\
\text { childrearing }\end{array}$ & $\begin{array}{l}\text { Breastfeeding, } \\
\text { diverse diet and } \\
\text { nutrition }\end{array}$ & $\begin{array}{l}\text { Activities that } \\
\text { encourage } \\
\text { caregiver to play } \\
\text { with the child and } \\
\text { build toys from } \\
\text { basic materials }\end{array}$ & $\begin{array}{l}\text { Activities that } \\
\text { encourage } \\
\text { caregiver to } \\
\text { play with the } \\
\text { child and be } \\
\text { kind with child } \\
\end{array}$ & $\begin{array}{l}\text { Activities that } \\
\text { encourage } \\
\text { caregiver to play } \\
\text { with the child and } \\
\text { be kind with child }\end{array}$ & $\begin{array}{l}\text { Breastfeeding, } \\
\text { diverse diet } \\
\text { and nutrition }\end{array}$ \\
\hline
\end{tabular}


A2.3 Home visitors

\begin{tabular}{|c|c|c|c|c|c|c|c|}
\hline Country & Brasil & Ecuador & Panama & Peru & Jamaica & Nicaragua & Bolivia \\
\hline Program & $\begin{array}{l}\text { Primera } \\
\text { Infancia } \\
\text { Melhor } \\
\text { (PIM) }\end{array}$ & $\begin{array}{l}\text { Creciendo con } \\
\text { nuestros hijos } \\
\text { (CNH) }\end{array}$ & $\begin{array}{c}\text { Atención } \\
\text { Integral de la } \\
\text { Niñez en la } \\
\text { Comunidad } \\
\text { (AIN-C) }\end{array}$ & Cuna Mas & Home-Visit Program & $\begin{array}{c}\text { Programa de } \\
\text { Acompañamiento } \\
\text { a la Política de } \\
\text { Primera Infancia } \\
\text { (PAIPPI) }\end{array}$ & $\begin{array}{c}\text { Consejo de } \\
\text { Salud Rural } \\
\text { Andino - Home } \\
\text { Visit Program } \\
\text { (CSRA) }\end{array}$ \\
\hline Staff * & 2,733 & 6,055 & 755 & 5,000 & & 3.000 & \\
\hline $\begin{array}{l}\text { Years of } \\
\text { education }\end{array}$ & 12 & 13 & 5 & 11 & & & \\
\hline $\begin{array}{l}\text { Salary } \\
\text { (US.\$/month) }\end{array}$ & $\begin{array}{l}\text { Minimum } \\
\text { salary }{ }^{* *}\end{array}$ & 370 & 50 (incentive) & 150 (stipend) & & 40 (stipend) & \\
\hline Profile & $\begin{array}{l}\text { Visitors: at } \\
\text { least high } \\
\text { school (not } \\
\text { a } \\
\text { requiremen } \\
\text { t) }+60 \\
\text { hours of } \\
\text { training } \\
\text { (more if no } \\
\text { high school } \\
\text { degree). }\end{array}$ & $\begin{array}{l}\text { Community } \\
\text { workers: high } \\
\text { school degree } \\
\text { with focus in } \\
\text { teaching/univers } \\
\text { ity }+1 \text { year of } \\
\text { experience with } \\
\text { children }\end{array}$ & $\begin{array}{l}\text { Literacy and } \\
\text { Spanish } \\
\text { proficient }\end{array}$ & $\begin{array}{l}\text { Literate } \\
\text { men/women } \\
\text { with at least } \\
\text { primary } \\
\text { complete, } \\
\text { knowledge of } \\
\text { the mother } \\
\text { tongue of } \\
\text { children of the } \\
\text { community, } \\
\text { minimum age } \\
\text { of } 21 \text { years } \\
\text { and in } \\
\text { experience in } \\
\text { community } \\
\text { work with } \\
\text { families }\end{array}$ & $\begin{array}{l}\text { Most have completed } \\
\text { secondary or some } \\
\text { secondary education. } \\
\text { Some have gone on to } \\
\text { do additional 1-year } \\
\text { practical nursing } \\
\text { program. In the most } \\
\text { recent program (clinic- } \\
\text { based program) the } \\
\text { visitors were } \\
\text { community health } \\
\text { aids. All visitors } \\
\text { receive additional } \\
\text { training in early } \\
\text { childhood r } \\
\text { development, early } \\
\text { stimulation, home } \\
\text { visiting techniques, } \\
\text { and relationship } \\
\text { building. }\end{array}$ & $\begin{array}{l}\text { Completed high } \\
\text { school, and very } \\
\text { few have completed } \\
\text { technical or } \\
\text { university studies. } \\
\text { Some visitors are } \\
\text { pre-school } \\
\text { teachers. Visitors } \\
\text { receive initial } \\
\text { training from the } \\
\text { municipal technical } \\
\text { supervisor in early } \\
\text { childhood and } \\
\text { development and } \\
\text { visit methodology, } \\
\text { from two days to } \\
\text { one week. }\end{array}$ & $\begin{array}{l}\text { All visitors are } \\
\text { professionals in } \\
\text { the fields of } \\
\text { health, nutrition } \\
\text { and medicine; } \\
\text { most have } \\
\text { previous } \\
\text { experience as } \\
\text { community } \\
\text { health workers. } \\
\text { All received } \\
\text { extensive } \\
\text { training in } \\
\text { maternal and } \\
\text { infant health and } \\
\text { nutrition, social } \\
\text { work, theater, } \\
\text { and participatory } \\
\text { education } \\
\text { methods. }\end{array}$ \\
\hline
\end{tabular}

Staff includes personnel in charge of visits or groups sessions and supervisors (when data is available)

** The exchange rate used was from 31 December, 2011: 1.86 reais per US dollar. 


\section{Appendix 3: Suggestions to improve the Checklist Instrument}

Below are suggestions to improve the checklist instrument in specifics items listed:

\section{Actividades y metodología}

\begin{tabular}{|l|c|c|c|c|}
\hline $\begin{array}{l}\text { 11. La manera como la educadora } \\
\text { explicó el objetivo de las actividades } \\
\text { (lo que el niño debe lograr) fue: }\end{array}$ & Buena & Regular & Insuficiente & $\begin{array}{c}\text { No explicó el } \\
\text { objetivo }\end{array}$ \\
\hline
\end{tabular}

Suggestions: This question may need to be clarified or made more specific. Most home visitors are very good at explaining to the mother how to do the activity, but few home visitors consistently explain why the activity is important (i.e. this activity "helps child recognize patterns,") and how it relates to the child's particular stage of development (to be sure, this requires a solid understanding of child development, which all home visitors SHOULD have, although in practice not all have the education/training necessary to explain these concepts to the mother/caregiver.

\begin{tabular}{l|l|l|l|l}
$\begin{array}{l}\text { 12. La manera como la educadora } \\
\text { modeló las actividades para la } \\
\text { cuidadora fue: }\end{array}$ & Buena & Regular & Insuficiente & $\begin{array}{l}\text { No las } \\
\text { modeló }\end{array}$ \\
\hline
\end{tabular}

Suggestions In practice, it can be hard to distinguish between "good" and "adequate" demonstration of activities, as most activities are very simple to demonstrate.

\begin{tabular}{l|l|l|c|c|}
$\begin{array}{l}\text { 17. ¿La educadora habló sobre temas } \\
\text { no relacionados a los objetivos de la } \\
\text { visita con la cuidadora u otros } \\
\text { miembros del hogar? }\end{array}$ & No, nunca & Muy poco & $\begin{array}{c}\text { Sí, en } \\
\text { algunos } \\
\text { momentos }\end{array}$ & $\begin{array}{c}\text { Sí, mucho } \\
\text { (demasiad) }\end{array}$ \\
\hline
\end{tabular}

Suggestions: This item could probably be eliminated, there was next to no variation (all home visitors except for one scored 4 ("never").

\section{Relación entre la educadora y la cuidadora}

\begin{tabular}{|c|c|c|c|c|}
\hline & & & & \\
\hline \multicolumn{5}{|l|}{$\begin{array}{l}\text { Suggestions This item does not neces } \\
\text { visitors will ask if the mother "has any }\end{array}$} \\
\hline
\end{tabular}




\section{Relación entre la educadora y el niño}

\begin{tabular}{|c|c|c|c|c|}
\hline $\begin{array}{l}\text { 27. ¿En general la relación entre la educadora } \\
\text { y el niño fue de calidez, comprensión, y } \\
\text { cooperación? }\end{array}$ & $\begin{array}{l}\text { Sí, la mayor } \\
\text { parte del } \\
\text { tiempo }\end{array}$ & $\begin{array}{l}\text { Sí, parte } \\
\text { del } \\
\text { tiempo }\end{array}$ & $\begin{array}{c}\text { Casi } \\
\text { nunca }\end{array}$ & Nunca \\
\hline
\end{tabular}

\section{Participación}

\begin{tabular}{|c|c|c|c|c|}
\hline $\begin{array}{l}\text { 29. ¿Participó la cuidadora } \\
\text { activamente a lo largo de la } \\
\text { visita? }\end{array}$ & $\begin{array}{l}\text { Sí, la mayor } \\
\text { parte del } \\
\text { tiempo }\end{array}$ & $\begin{array}{l}\text { Sí, parte del } \\
\text { tiempo }\end{array}$ & Casi nunca & Nunca \\
\hline \multicolumn{5}{|c|}{$\begin{array}{l}\text { Suggestions Many home visitors do a good job getting the mother to participate actively in the } \\
\text { activities with the child (giving her time to do the activities alone with the child), but very few } \\
\text { home visitors give orientation or feedback in a way that encourages the mother to speak up. } \\
\text { Thus, it might be good to separate, one item that measures mother's active participation in the } \\
\text { hands-on activities, and one item that measures mother's participation in the } \\
\text { orientation/counseling part of the visit. }\end{array}$} \\
\hline $\begin{array}{l}\text { 30. ¿Cómo calificaría la actitud } \\
\text { de la educadora durante la } \\
\text { visita? }\end{array}$ & $\begin{array}{l}\text { Hizo mucho } \\
\text { esfuerzo } \\
\text { para } \\
\text { provocar la } \\
\text { participación } \\
\text { y promovió } \\
\text { la confianza }\end{array}$ & $\begin{array}{c}\text { Hizo } \\
\text { esfuerzo } \\
\text { adecuado } \\
\text { para } \\
\text { provocar la } \\
\text { participación } \\
\text { y promovió la } \\
\text { confianza }\end{array}$ & $\begin{array}{l}\text { No promovió } \\
\text { suficiente la } \\
\text { participación } \\
\text { y confianza }\end{array}$ & $\begin{array}{l}\text { Actuaba de } \\
\text { manera muy } \\
\text { dominante }\end{array}$ \\
\hline
\end{tabular}

